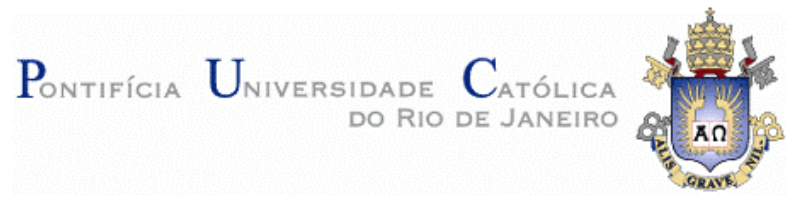

Yaimara Pérez Alvarez

O Dano Moral como lesão ao princípio constitucional da dignidade humana. Perspectiva comparada entre os sistemas cubano e brasileiro

Dissertação de Mestrado

Dissertação apresentada como requisito parcial para obtenção do grau de Mestre pelo Programa de PósGraduação em Direito da PUC-Rio.

Orientadora: Prof ${ }^{\mathrm{a}}$ Caitlin Sampaio Mulholland

Rio de Janeiro Outubro de 2017 


\section{O Dano Moral como lesão ao princípio constitucional da dignidade humana. Perspectiva comparada entre os sistemas cubano e brasileiro}

Dissertação apresentada como requisito parcial para obtenção do grau de Mestre pelo Programa de Pós-Graduação em Direito do Departamento de Direito da PUC-Rio. Aprovada pela Comissão Examinadora abaixo assinada.

Prof ${ }^{\mathrm{a}}$. Caitlin Sampaio Mulholland Orientadora

Departamento de Direito - PUC-Rio

Prof ${ }^{a}$. Maria Celina Bodin de Moraes

Departamento de Direito - PUC-Rio

Prof. Carlos Edison do Rego Monteiro Filho Departamento de Pós-Graduação em Direito - UERJ-Rio

Prof. Augusto César Pinheiro da Silva Vice-Decano Setorial de Pós-Graduação do Centro de Ciências Sociais - PUC-Rio 
Todos os direitos reservados. É proibida a reprodução total ou parcial do trabalho sem autorização da universidade, do autor e do orientador.

Yaimara Pérez Alvarez

Graduou-se em Direito pela Universidade de Camagüey Ignacio Agramonte Loynaz - Cuba em 2012.

Ficha Catalográfica

\begin{tabular}{|} 
Pérez Alvarez, Yaimara \\
O dano moral como lesão ao princípio constitucional \\
da dignidade humana. Perspectiva comparada entre os \\
sistemas cubano e brasileiro / Yaimara Pérez Alvarez; \\
orientadora: Caitlin Sampaio Mulholland. - 2017. \\
133 f. : il. color. ; 30 cm \\
Dissertação (mestrado)-Pontifícia Universidade \\
Católica do Rio de Janeiro, Departamento de Direito, 2017. \\
Inclui bibliografia \\
1. Direito - Teses. 2. Dano moral. 3. Dignidade da \\
pessoa humana. $\quad$ 4. Direito Civil-Constitucional. 5. \\
Compensação judicial. 6. Cuba. 7. Brasil. I. Mulholland, \\
Caitlin Sampaio. II. Pontifícia Universidade Católica do Rio \\
de Janeiro. Departamento de Direito. III. Título.
\end{tabular}

CDD: 340 
Aos amores da minha vida: meus pais Mariela Alvarez Fuentes e Ricardo Jorge Pérez Gallardo por todo seu amor, esforço e apoio, embora a distância nos separe nossos corações estão sempre unidos, eu amo vocês com toda minha alma; e a meu esposo Jorge Raúl Pérez Arredondo por ser meu alento e inspiração, todos meus logros são frutos de nosso grande amor. 


\section{Agradecimentos}

Agradecer é uma virtude que poucas pessoas sabem expressar, significa gratidão pela ajuda desinteressada e incondicional de outra pessoa. Eu me sinto abençoada pela generosidade recebida, por isso quero agradecer a todos os que de uma forma ou outra fizeram aportes na realização do presente trabalho.

Minha orientadora Caitlin Sampaio Mulholland desempenhou um papel essencial teve a coragem de orientar uma estudante estrangeira que apenas dominava o idioma e ainda assim aceitou o desafio de assumir e conduzir minha pesquisa com a melhor atenção, dedicação e carinho. Eternamente grata com você.

Meu "velhinho" merece todo meu agradecimento por simplesmente me alentar e aconselhar com amor, paciência, consideração e apoio, sendo meu amigo e companheiro. A toda minha família, em especial os meus pais e meus irmãos: Kirenia Fernández Alvarez e Yuniel Pérez Alvarez, por ser o impulso que me motivam a seguir avançando.

Aos membros da Comissão Examinadora pelas contribuições feitas; aos Professores da PUC-Rio dos Departamentos de Direito e de Letras pela sólida formação acadêmica, à Coordenadora Gisele Cittadino pela confiança depositada; aos secretários Carmen e Anderson por toda sua ajuda. À PUC-Rio, por acreditar na pesquisa em direito e a CNPq pelos auxílios financeiros brindados.

Agradeço as valiosas revisões feitas por minhas amigas Isabella Frajhof, Mariana Sacramento e Luana Couto, e os aportes consideráveis de Anne Bénédicte. A minha amiga de sempre Yoana Roja Blanco, por estar nos momentos bons e também nos mais difíceis, demonstrando sua amizade sincera. Ao advogado cubano Raúl Ruíz Larrúa, pela informação brindada. Às professoras Yadermis Tejeda, Iris Cabanes Espino e Yaimara Martínez por toda a ajuda oferecida.

A meus sogros, minhas cunhadas, e a Cheché por toda a ajuda e o carinho oferecido. Para o final, reservo o principal agradecimento a Deus por sempre guiar meu caminho. "MUITO OBRIGADA". 


\section{Resumo}

Pérez Alvarez, Yaimara; Sampaio Mulholland, Caitlin (Orientadora). O Dano Moral como lesão ao princípio constitucional da dignidade humana. Perspectiva comparada entre os sistemas cubano e brasileiro. Rio de Janeiro, 2017. 133 p. Dissertação de Mestrado - Departamento de Direito, Pontifícia Universidade Católica do Rio de Janeiro.

A dignidade da pessoa humana é um dos fundamentos que todo Estado deve resguardar e preservar. A violação injusta de seus elementos gera irremediavelmente um dano moral que conduz ao ressarcimento da vítima, com o intuito de restabelecer a situação anterior à ocorrência do dano, colocando-a novamente no pleno desfrute dos direitos que lhe foram lesionados. No caso do Brasil, o dano moral tem reparação econômica constitucionalmente regulada, mas sua interpretação e aplicação judicial, em alguns casos, não respondem aos critérios doutrinários e constitucionais existentes, diante dos altos valores fixados a título de compensação e a inobservância dos elementos que compõem a responsabilidade civil, ressarcindo-se economicamente a maioria das demandas apresentadas. Em Cuba, encontra-se reconhecida constitucionalmente a dignidade humana como fundamento do Estado, sendo a lei primeira no sistema; não obstante, quando ocorre a ofensa de seus elementos, sua reparação se limita à retratação pública do ofensor, não se encontrando o reparo econômico como opção legítima para ressarcir o dano moral ocasionado, tornando, assim, escassas a proteção do indivíduo e a aplicabilidade do dano moral. As dificuldades que apresentam os dois países podem ser superadas a partir da valoração dos ordenamentos jurídicos como um todo, visando a reparação do dano extrapatrimonial desde a perspectiva do direito civil-constitucional, sendo possível em Cuba a reparação econômica do dano extrapatrimonial justificada nas leis e instituições que conformam o sistema; e no caso do Brasil, além da reparação pecuniária, pode-se adotar a retratação pública do ofensor como possibilidade inserida no direito de resposta.

\section{Palavras-chave}

Dano Moral; Dignidade Humana; Direito Civil-Constitucional; Compensação Judicial; Cuba; Brasil. 


\section{Abstract}

Pérez Alvarez, Yaimara; Sampaio Mulholland, Caitlin (Advisor). The Moral Damage as an injury to the constitutional principle of the human dignity. Comparative perspective between the Cuban and Brazilian systems. Rio de Janeiro, 2017. 133 p. Dissertação de Mestrado Departamento de Direito, Pontifícia Universidade Católica do Rio de Janeiro.

The dignity of the human person is one of the foundations that every State must safeguard and preserve. The unjust violation of its elements irrevocably results in moral damage that leads to reimbursement of the victim, with the purpose of restoring the situation prior to the occurrence of the damage, putting him or her again in full enjoyment of the rights that were injured. In the case of Brazil, moral damages have regulated economic reparations constitutionally, but their interpretation and judicial application, in some cases, do not respond to the existing doctrinal and constitutional criteria, given the high values set as compensation and the nonobservance of elements that make up liability. In Cuba, human dignity is constitutionally recognized as the foundation of the state, being the first law in the system; nevertheless, when the offense of its elements occurs, its reparation is limited to the public retraction of the offender, not finding the economic repair as a legitimate option to reimburse the moral damage occasioned, thus making scarce the protection of the individual and the applicability of the moral damage. The difficulties presented by the two countries can be overcome by assessing the legal systems as a whole, seeking the reparation of extra-judicial damages from the perspective of civil-constitutional law, and in Cuba it is possible to obtain economic reparation for the off-balance-sheet damage justified by the laws and institutions that make up the system; and in the case of Brazil, in addition to pecuniary reparation, it is possible to adopt the public retraction of the offender as a possibility inserted in the right of reply.

\section{Keywords}

Moral Damage; Human Dignity; Civil-Constitutional Law; Judicial Compensation; Cuba; Brazil. 


\section{Sumário}

1. Introdução

2. Valoração do Tratamento do Dano Moral no Ordenamento Jurídico Cubano.

2.1. Antecedentes da Responsabilidade Civil e do Dano Moral no sistema cubano.

2.2. Breve caracterização do sistema político, econômico e social existente em Cuba.

2.3. Conceito do dano moral na doutrina cubana e estrangeira.

Necessidade da sua redefinição.

2.4. Critérios para a qualificação do Dano Moral. Necessidade da configuração do ato injusto.

2.5. Discussão acerca da reparação pecuniária do dano moral.

Necessidade de seu reconhecimento.

2.6. Exame do dano extrapatrimonial no sistema legal cubano.

Especial referência ao Código Civil

2.6.1. Responsabilidade Civil proveniente do delito e sua regulação no Código Penal.

2.7. Valoração das resoluções emitidas pelo Tribunal Provincial Popular de Camagüey, Cuba, nos últimos 10 anos.

3. Tratamento e aplicação do Dano Moral no Ordenamento Jurídico Brasileiro.

3.1. Evolução da Responsabilidade Civil e seus elementos distintivos. 54

3.2. Definição do Dano Moral. Uma tese ainda em desenvolvimento. 60

3.3. O Princípio da Dignidade da Pessoa Humana como fundamento constitucional do Direito de Danos

3.4. Identificação e Reparação do Dano Moral no Brasil. 
3.4.1. Partes integrantes no litigio por danos morais

3.5. Apreciação dos Critérios adotados pelos juízes brasileiros para a quantificação do Dano Moral.

3.5.1. Dano Punitivo

3.6. Valoração das Resoluções emitidas pelo Tribunal de Justiça do Estado de Rio de Janeiro no primeiro semestre do ano 2017.

4. Proposta Jurídica para a melhor interpretação e aplicação do dano moral em ambos os sistemas de direito.

4.1. Discutir a possibilidade da adoção (não legislativa) do ressarcimento econômico do Dano Moral em Cuba.

4.2. Possibilidade de utilização contemporânea da retratação pública, pode-se entender como direito de resposta prevista na Constituição Federal?

4.3. Possibilidade da adoção (não legislativa) da retratação no

Brasil por meio da aplicação do Direito Civil-Constitucional

5. Conclusão

6. Referências bibliográficas 


\section{1. Introdução}

A presente dissertação tem como principal objetivo o estudo do dano moral, em especial, a realização de uma valoração crítica da interpretação e aplicação deste instituto do direito, tanto no âmbito doutrinário quanto na jurisprudência cubana e brasileira, nos casos em que a dignidade da pessoa física ou natural é atingida de forma injusta.

Embora sejam completamente diferentes os sistemas jurídicos adotados, tendo em conta sua organização econômica, política e social, ou como diria Roberto Gargarella, “a sala de máquinas da Constituição” (GARGARELLA, 2014), ambos possuem um elemento comum, uma vez que pertencem à tradição romano-germânica, o que sem dúvida propicia o estudo comparado de ambos os ordenamentos jurídicos, sendo possível adotar elementos legais e teóricos, de forma análoga, que facilitem a interpretação e aplicação do dano extrapatrimonial ${ }^{1}$.

Em virtude do caráter mutável do desenvolvimento da humanidade e ante a necessidade de enaltecer a dignidade da pessoa humana, percebendo a supremacia das situações existenciais sobre as patrimoniais, torna-se imprescindível o estudo do dano moral, pois, a própria vida em sociedade faz possível a incessante proliferação de danos de toda índole. Precisamente, nesta realidade, tem origem a relevância da presente discussão, diante da convivência em um mundo onde permanece a vontade de guerra, impera a instabilidade jurídica, política e social e o detrimento dos direitos que completam a identidade do ser humano digno.

Com a evolução assustadora das máquinas e da tecnologia de forma geral os danos estão acontecendo com maior rapidez e fluidez, resultando o seu tratamento ainda mais complexo. Por tal motivo, é necessário um exame que permita esclarecer o que é o dano moral, quais fatos merecem amparo judicial e quais são

\footnotetext{
${ }^{1}$ Para os efeitos da presente dissertação, entende-se a similitude entre dano moral e dano extrapatrimonial, toda vez que, o prejuízo não repercute no patrimônio da pessoa, senão que se constitui independentemente da afetação econômica que possa ocasionar-se, incidindo nos aspectos existenciais da pessoa humana; por consequência, identificam-se os preceitos: dano moral e dano extrapatrimonial.
} 
as formas pelas quais a vítima pode ser compensada. De igual forma, cabe analisar não apenas as faculdades dos lesados, senão também distinguir ante quais situações deve responder o lesante, já que, existem outros eventos derivados do acontecer cotidiano que devem ser tolerados pelo ofendido.

Não são poucos os estudos, dissertações e demais trabalhos que têm feito aportes consideráveis ao tema escolhido. Por esta razão, serão adotados os aspectos que sintetizam e fazem mais propício seu entendimento e aplicação. Desta forma, será ilustrado o tratamento desigual concedido ao tema em estudo, tanto em Cuba, como no Brasil; uma vez que, naquele não se regula nem se aplica o ressarcimento econômico dos acontecimentos que infringem a esfera existencial da pessoa; enquanto no segundo se evidencia a sua completa reparação econômica; no entanto, algumas vezes, constitui-se o sobre ressarcimento em sede judicial, ao reparar-se a maioria dos danos que se apresentam, sem propriamente configurar-se um dano moral; concedendo-se valores muito altos nas reparações, não se adotando, assim, outras formas que possibilitam a compensação do lesado e que não necessariamente se traduzem em dinheiro.

Ante as controvérsias existentes tanto na doutrina quanto na jurisprudência com relação ao dano extrapatrimonial, surge a necessidade de olhar o instituto jurídico desde a perspectiva do direito civil-constitucional, enaltecendo a ponderação dos atributos da dignidade da pessoa humana, como o elemento que deve ser tutelado. Através dos princípios constitucionais da dignidade da pessoa humana, solidariedade social e justiça distributiva; justifica-se o ressarcimento do dano moral em todo sistema democrático de direito (BODIN DE MORAES, 2003, p. 110). Em correspondência com o antes expressado, colige-se a necessidade da interpretação do todo o sistema jurídico à luz da Constituição, como lei suprema que conduz o funcionamento do aparelho legal, e à qual guardam obediência iniludível os entes subordinados, o Estado e a sociedade de forma geral.

Em toda sociedade deve prevalecer a consideração da pessoa em si e o reconhecimento pela outra pessoa que faz parte da mesma coletividade. Porém, essa consideração não deve estar sustentada em estratégias que permitam a prevalência de um interesse sobre o outro, mas sim em formas que se revelam em entendimento, empatia e tolerância pelo próximo. Justamente, com sustento nas disposições constitucionais que regem em Cuba e no Brasil serão apresentadas 
propostas que podem tornar o trabalho de juiz mais justo e equitativo, tutelando a dignidade humana ante toda vulneração que lese injustamente seus componentes.

Na primeira parte do trabalho, será abordado o tratamento do dano moral no ordenamento jurídico cubano, partindo da análise do próprio sistema político instaurado em Cuba, e fundamentando a necessidade de seu ressarcimento com base nos preceitos civis e constitucionais. Igualmente, em virtude da interpretação análoga de outras fontes legais que integram o sistema normativo cubano, pode ser fundamentada a reparação econômica do dano moral. Além disso, será feita uma valoração detalhada de sua identificação e quantificação, tanto pela doutrina como pelo poder judicial através do exame das resoluções judicias do Tribunal Provincial Popular de Camagüey (TPP) nos últimos dez anos.

Posteriormente, será abordado como o instituto em estudo é regulamentado no sistema jurídico brasileiro, analisando sua evolução, identificação, quantificação, a aplicação do dano punitivo em sede judicial, bem como sua vasta consideração por diferentes normas legais. Avaliando-se as demandas que foram resolvidas pelo Tribunal de Justiça do Estado do Rio de Janeiro (TJRJ) no primeiro semestre do ano 2017, através das quais, pode-se corroborar a prática costumeira e desmedida dos casos que analisaram pedidos de dano moral e seu correspondente ressarcimento econômico.

Finalmente vão ser apresentadas propostas, através das quais se demonstra a possibilidade da adoção de normas legais similares que podem ser aplicadas em ambos os sistemas de direito, tendo como principal expoente normativo a Carta Magna, à qual se subordina todo o sistema legal, cujas normas devem ser consideradas e ponderadas em todo caso em que se ventile um dano moral, demonstrando-se a possibilidade de adotar tanto a retratação pública como o pago pecuniário, como vias eficazes para reparar ao lesado, podendo coexistir ambas as vias na argumentação judicial de um mesmo assunto ou ser aplicadas de forma independente em correspondência com as características do litígio. 


\section{2. \\ Valoração do Tratamento do Dano Moral no Ordenamento Jurídico Cubano.}

\section{1. Antecedentes da Responsabilidade Civil e do Dano Moral no sistema cubano.}

A discussão e análise da responsabilidade civil retornam-se à antiguidade, quando ainda não existiam leis que codificavam as condutas, os direitos dos indivíduos e as sanções pelos atos ilícitos das pessoas. Desde o Código de Hamurabi consignavam-se juridicamente os procedimentos legais para a imposição de penas e outras normas legais de grande envergadura naquela época. (VEGA CARDONA e ORDELÍN FONT, 2012)

O direito romano, de igual forma, incidiu de forma positiva na delimitação e concepção da responsabilidade civil. Neste período, foi elaborada a lei XII Tábulas, onde constam três grandes manifestações do direito: o ius civile, ius naturale e ius gentium. (FERNÁNDEZ BULTÉ, 1997). Também, tiveram origem os preceitos que regem esta instituição e a obrigação moral como premissa da convivência pacífica da sociedade: honeste vivere (viver honestamente), alterum non laedere (não danar a outro) e suum cuique tribuere (dar a cada qual o que lhe pertence). (PÉREZ GALLARDO, RODRÍGUEZ OJEDA, et al., 1999, p. 20)

Com a prática dos jurisconsultos bizantinos a culpa, como elemento da responsabilidade civil, foi instituída para determinar uma obrigação específica (LLAMBIAS, BENEGAS RAFFO e SASSOT, 1997, p. 554). Todas estas considerações foram variando diante da própria evolução da humanidade, e também aos novos códigos que foram nascendo e criando uma visão distinta do instituto em estudo, como é o caso do Código Civil Francês, ${ }^{2}$ que significou uma grande referência, sobretudo, para os países da tradição romano-germânica, ao

2 O art. 1382 do Código Napoleão de 1804 trata da responsabilidade por ato próprio, com a seguinte redação: Tout fait quelconque de l'homme, qui cause à autrui um dommage, oblige celui par la faute duquel il est arrivé, à le réparer. Trad.: Qualquer fato oriundo daquele que provoca um dano a outrem obriga aquele que foi a causa do que ocorreu a reparar este dano. (LLAMBIAS, BENEGAS RAFFO e SASSOT, 1997, p. 558) 
2.

estipular a obrigação de reparar qualquer dano que fosse causado de forma culposa. (DIEZ PICAZO, 2016, p. 153)

Os primeiros códigos que registraram esta matéria pretendiam castigar os indivíduos, cujas condutas geravam um determinado prejuízo a outra pessoa. Nesse momento, não se procurava reparar a lesão criada, senão punir o responsável pelo ato, utilizando para tanto a responsabilidade subjetiva, que exigia a presença de culpa ou dolo para que ficasse configurada a obrigação de ressarcir. (VALDÉS DÍAZ, PÉREZ GALLARDO, et al., 2000, p. 324) Quase todos os códigos do século passado abraçaram este tipo de responsabilidade. Não obstante, foram surgindo outros mais vanguardistas que perceberam a responsabilidade civil a partir do risco gerado, independentemente da culpa do responsável. ${ }^{3}$

Estes entendimentos deram origem à responsabilidade objetiva ou de risco, que ocorria naqueles casos em que não se precisava da demonstração da culpa para conceder reparação ao lesado. De igual forma, esta perspectiva doutrinária e jurisprudencial, que permitia admitir este tipo de responsabilidade, foi consequência da Lei Francesa de Acidentes de Trabalho de 1896, na qual se estabelecia o dever do empregador de indenizar ao trabalhador por qualquer risco produzido. (DIEZ PICAZO, 2016, p. 153)

A partir de então, o sentimento de vingança ficou substituído pela noção de justiça, não se procurando o castigo de quem provocava a lesão, senão a reparação da vítima do prejuízo. Isto se derivou dos progressos da revolução industrial que geravam riscos e sinistros pelo desconhecimento ou imperícia na utilização dos novos progressos tecnológicos, mas também, pela dificuldade de provar a culpa do agente, ocorrendo, por vezes, uma injustiça para o demandante, nas hipóteses em que não era possível comprovar a conduta infratora (VALDÉS DÍAZ, PÉREZ GALLARDO, et al., 2000, p. 325-326).

\footnotetext{
${ }^{3}$ Art. 2050 do Código Civil italiano de 1942: Responsabilità per l'esercizio di attività pericolose "Chiunque cagiona danno ad altri nello svolgimento di un'attività pericolosa, per sua natura o per la natura dei mezzi adoperati, e tenuto al risarcimento, se non prova di avere adottato tutte le misure idonee a evitare il danno". Trad: "qualquer um que causa um dano a outrem no desempenho de uma atividade perigosa por sua natureza, ou pela natureza dos meios adotados, deve repará-lo, se não provar ter adotado todas as medidas adequadas para evitá-lo". (DIEZ PICAZO, 2016, p. 156)

Art. 927 parágrafo único do Código Civil brasileiro de 2002: Haverá obrigação de reparar um dano, independentemente de culpa, nos casos especificados em lei, ou quando a atividade normalmente desenvolvida pelo autor do dano implicar, pela sua natureza, riscos para os direitos de outrem (BRASIL. Lei 10.406, 10 de janeiro de 2002).
} 
2.

Assim ficou configurada a responsabilidade civil, através da qual a vítima de um dano tinha a faculdade de exigir ao ofensor uma determinada conduta. Justamente o próprio vocábulo "obrigação" tem origem na palavra latina obligatio, que se deriva de obligare, $o b$ (ao redor) e ligare (ligar, atar), o que se traduz em ligadura, sujeição, adequando-se à ideia de "sujeição patrimonial". (OJEDA RODRÍGUEZ e TERESA, 2000, p. 34). O instituto em questão não se confunde com a responsabilidade jurídica contratual, que nasce a partir do contrato. A responsabilidade civil extracontratual, pelo contrário, não está regida por um contrato pré-estabelecido, mas constitui-se ante uma ação danosa provocada por uma pessoa com a qual não se tinha vínculo nenhum. (PÉREZ GALLARDO, RODRÍGUEZ OJEDA, et al., 1999, p. 58).

$\mathrm{O}$ objetivo da responsabilidade civil é reparar o dano ocasionado à pessoa alheia, que deve ser compensada da forma mais abrangente possível, sempre procurando restabelecê-la à situação na que se encontrava antes de suportar o dano. Esta necessidade de conceder proteção à vítima, melhorando sua situação processual e jurídica vem justificada pelo chamado "direito de danos", termo utilizado por vários autores que abandonaram o conceito de responsabilidade civil (VEGA CARDONA e ORDELÍN FONT, 2012), em virtude da ampliação das hipóteses de reparação dos danos, com independência da demonstração de culpa. $\mathrm{O}$ direito de danos vem sendo utilizado como meio eficaz para consagrar a dignidade humana. Através dele, recebem proteção legal os interesses existenciais, incluindo aqueles que não se encontram previstos em leis.

O principal desafio do direito de danos é ponderar adequadamente os prejuízos e atribuí-lhes quantias justas que propiciem o ressarcimento da vítima, reparando integralmente as lesões que lhe foram causadas. As mais modernas tendências doutrinárias e legislativas percebem a responsabilidade objetiva como um segundo pilar do direito de danos, ao lado da culpa. O antes debatido foi explicado pelo professor Luis Díez-Picazo, quem de forma acertada, concebeu a reparação do dano extrapatrimonial como o epicentro da responsabilidade civil através do surgimento da figura do direito de danos:

(...) surge (...) el primero de los principios del moderno Derecho de daños: un principio pro damnato o del resarcimiento del daño. De manera que van perdiendo paulatinamente importancia los demás factores que imponía la disciplina codificada, que tienen que ser objeto de sucesivas reelaboraciones de la jurisprudencia. Primero, la culpa (...). Después, los embates que experimenta la figura de la causalidad (...). La conclusión de todo ello, sencillamente expuesta, 
2.

me parece que es que ya no hay que reparar, porque existió antes una conducta reprobable, sino que hay que reparar a secas; que no se trata tanto de moralizar las conductas de los eventuales autores de los daños como de asegurar las indemnizaciones a las víctimas. ${ }^{4}$

Em Cuba se entendem como elementos da responsabilidade civil: a culpa ou dolo, o dano e o nexo de causalidade entre ambos (PÉREZ GALLARDO, RODRÍGUEZ OJEDA, et al., 1999, p. 76). Há autores que agregam o elemento da ilicitude da ação ou a omissão que provocou o dano (OJEDA RODRÍGUEZ e TERESA, 2000, p. 96). Uma vez presentes os elementos da responsabilidade civil, o demandado é obrigado a ressarcir o prejuízo causado ao demandante.

O dano é considerado o principal elemento do instituto antes aludido. A maior parte da doutrina entende que a sua ausência implica na não configuração da responsabilidade civil, uma vez que ela exerce sua função quando a obrigação inserida na sociedade é vulnerada, produzindo-se uma lesão no patrimônio alheio. Os danos, em relação a sua natureza, podem ser patrimoniais (materiais) e extrapatrimoniais (imateriais ou morais). Os primeiros se evidenciam quando há prejuízo no patrimônio, manifestando-se na diferença entre o que se tem e o que se teria caso não houvesse ocorrido o evento danoso, chamada "Teoria da Diferença”. (BODIN DE MORAES, 2003, p. 143). Já os danos morais são os que atingem o ser humano na sua esfera personalíssima (BITTAR, 1994, p. 27).

Há quem distingue o dano moral e o material de acordo com o bem atingido. Consideram-se materiais os danos com repercussão econômica para o ofendido, ao contrário dos morais, que ocorrem mediante as turbações de ânimo, reações aborrecíeis ou outras neste âmbito, na esfera do lesado (BITTAR, 1994, p. 31). De acordo com o bem atingido, os danos morais podem ser perfeitamente diferenciados daqueles patrimoniais. Inclusive, os prejuízos morais podem ser puros, ou podem derivar ou serem reflexos de um dano patrimonial precedente. Consideram-se danos morais puros os que não precisam da configuração de detrimentos patrimoniais para provocar uma lesão nos elementos da dignidade

${ }^{44}$ Trad. (...) surge o primeiro dos princípios do moderno Direito de danos: um princípio pro damnato ou do ressarcimento do dano. De maneira que vão perdendo paulatinamente importância os demais fatores que impõem a disciplina codificada, que têm que ser objeto de sucessivas reelaborações da jurisprudência. Primeiro, a culpa (...). Depois, os embates que experimentam a figura da causalidade (...). A conclusão de tudo isso, simplesmente exposta, parece-me que já não há que reparar, porque existiu antes uma conduta reprovável, senão que há que reparar a secas; que não se trata de moralizar as condutas dos eventuais autores dos danos, como de assegurar as indenizações das vítimas. (DÍEZ PICAZO, 1979, p. 732) 
2.

humana, e receber amparo jurídico. Por enquanto, os danos reflexos são decorrentes daqueles atos que incidem diretamente no patrimônio do lesado. Pode-se concluir que a lesão provocada pode causar tanto dano moral como material, cuja reparação pode ser pleiteada de forma conjunta. (BITTAR, 1994, p. 48), atendendo de forma positiva ao princípio da economia processual.

O objeto da obrigação é uma questão discutida pela doutrina cubana. A mesma é concebida como a prestação que o lesante deve cumprir, e que está facultada ao lesado exigir. Esta prestação se identifica com o comportamento que o compelido deve adotar em favor do demandante, e que pode materializar-se através de um comportamento de dar, fazer ou não fazer determinada coisa ${ }^{5}$. (OJEDA RODRÍGUEZ e TERESA, 2000, p. 58) A origem desta definição deve passar a ser entendida à luz da amplitude do direito de danos, já que não só se limita apenas à proteção de bens meramente econômicos, mas de igual forma tutela interesses de outra natureza, sempre e quando sejam sérios e merecedores de amparo judicial. (OJEDA RODRÍGUEZ e TERESA, 2000, p. 63)

Em alusão ao tratamento do dano moral no sistema cubano, deve-se dizer que a sua regulação esteve condicionada pelos diferentes períodos existentes na história do país, obtendo um maior reconhecimento pela via penal do que pela civil. Durante muitos anos Cuba foi colônia espanhola, ficando todas suas leis, costumes e idiossincrasia influenciadas pelo direito Espanhol (PÉREZ GALLARDO, 2007). O Código Penal Espanhol se fez extensivo a Cuba em 23 de maio de 1879 , no qual foram introduzidos os delitos contra a honra, com uso do termo "patrimônio moral das pessoas" para fazer alusão aos interesses existenciais do ser humano. Posteriormente, foi redigido o Código de Defesa Social (CDS) em 10 de fevereiro de 1936, promulgado o dia 9 de outubro de 1938. Esta lei de natureza penalista tinha como objetivo não apenas o castigo do delinquente, senão também a defesa da sociedade contra as agressões do infrator, procurando a prevenção e a reeducação do mesmo. (LEÓN IGLESIAS, 2013).

O CDS teve como principal exponente legal o pensamento penal italiano. O Código era composto por quatro livros, entre os quais, abordavam os institutos das responsabilidades civis e criminais. (PÉREZ VÉLIZ, 2016, p. 162-168) No seu

\footnotetext{
${ }^{5}$ O objeto da relação jurídica encontra-se tipificado de forma clara pelo Código Civil Cubano, nos artigos 45.1 e 46.3. (CUBA, Ley No 59, 16 de Julio de 1987).
} 
2.

artigo 114 estava prevista a reparação do dano extrapatrimonial, compreendendo a satisfação pública da vítima mediante a desculpa do ofensor, o matrimônio do ofensor com a ofendida ${ }^{6}$, e o reconhecimento dos filhos quando não era possível, pela natureza da prole, a reparação em forma de dote, (SMITH RAMOS, 1983, p. 301-302) medida utilizada, geralmente, quando o filho era contraído fora do vínculo matrimonial, o caso dos chamados filhos ilegítimos, desigualdade que foi abolida pelo art. 37 da Constituição cubana de $1976 .^{7}$

De igual forma, a obrigação do matrimônio foi perdendo seu sentido gradativamente pela própria evolução dos costumes e das práticas morais da sociedade cubana. A emancipação plena da mulher resultou em um acontecimento inevitável onde ia adquirindo igualdade para exercer seus direitos cidadãos, e ocupando um lugar destacado na sociedade. (SMITH RAMOS, 1983, p. 331) Além disso, interpretava-se o matrimônio como uma união voluntária, e sendo a responsabilidade civil de cumprimento obrigatório para o sancionado, resultava incompatível este tipo de reparação com o dano moral.

Em matéria de dano moral o CDS trouxe preceitos inovadores para seu tempo, como a utilização dos meios de comunicação para reparar o dano extrapatrimonial causado às pessoas, tanto físicas quanto jurídicas. Nos casos em que a injúria ou calúnia ocorriam na publicação de um jornal, seus proprietários, gerentes e editores eram obrigados a retificar a ofensa, utilizando-se o mesmo caráter em que aquelas eram proferidas, e no prazo estabelecido pelo tribunal, reprimindo, portanto, o abuso do direito daqueles que exercitavam seus direitos à liberdade de palavra e à imunidade. (PÉREZ VÉLIZ, 2016, p. 169)

Nessa mesma época, a Constituição de 10 de outubro de 1940 regia a ilha, norma progressista para seu tempo, pois concedia numerosos direitos que

6 Estabelecia, como exceção, a possibilidade de substituir o casamento forçado por uma compensação econômica no caso em que concorria no réu impedimento absoluto para contrair matrimônio, quando a ofendida manifestava oposição para contrair matrimônio porque o réu lhe era repugnante, era um criminal habitual, reincidente; ou concorria em ele alguma circunstância permanente de periculosidade. (SMITH RAMOS, 1983)

${ }^{7}$ Artigo 37, trad.: Todos os filhos têm iguais direitos, sejam havidos dentro ou fora do matrimônio. (CUBA, Constitución de la República de Cuba, 24 de febrero de 1976).

Trad.: Por Quanto. Ainda subsistem em nosso país com relação à família, normas jurídicas do passado burguês, retrógradas e contrárias ao principio da igualdade, discriminatórias da mulher e dos filhos nascidos fora do matrimônio; normas que devem ser substituídas por outras que concordem plenamente com o princípio da igualdade e com as realidades de nossa sociedade socialista em contínuo e impetuoso avance. (CUBA, Ley 1289, Código de Familia, 14 de febrero de 1975). 
2.

enalteciam a honra da pessoa e sua dignidade. ${ }^{8}$ Porém, com o golpe de Estado liderado por Fulgencio Batista em 10 de março de 1952, por meio do Decreto-Lei 997 de 26 de julho de 1953, puseram fim às garantias constitucionais concedidas, coagindo-se e limitando-se a liberdade individual e coletiva, tanto das pessoas, como dos meios e órgãos de difusão, elaborando modificações no CDS, e substituindo-se a Constituição de 1940 pelos Estatutos Constitucionais. (PÉREZ VÉLIZ, 2016, p. 172) Estas mudanças significaram um retrocesso em matéria de direitos humanos, incidindo negativamente na materialização do dano moral, pois, foram suprimidas todas as garantias que enalteciam o ser humano digno, ficando substituídas por outras normas que desconsideravam a condição do indivíduo, quem se encontrava completamente desamparado ante aqueles atos que atingiam a sua dignidade, não podendo exigir a sua reparação, já que, as violações às que eram submetidos estavam condicionadas àquele período.

Em relação às leis civis que existiram na ilha anteriormente ao Código Civil atual, pode-se afirmar que quase nenhuma adotou o dano moral nas suas normas. O Código Civil Espanhol de 1889, apesar de reconhecer várias situações de vulnerações de direitos que possibilitavam a correspondente indenização por danos e prejuízos, não fazia menção expressa ao dano moral (SMITH RAMOS, 1983, p. 299). Embora Cuba já não estivesse mais sob o domínio Espanhol, nas primeiras três décadas do século XX, algumas disposições legais promulgadas durante o período colonial ainda permaneceram no sistema jurídico cubano.

Por sua vez, o sistema romano-francês se consolidou em Cuba na própria época colonial por meio do Código Civil Espanhol de 1889, que regeu na ilha até 1988, ${ }^{9}$ e o Código de Comércio Espanhol de 1886, influenciado pelo Código Francês. Em Cuba foram realizadas várias versões dos anteprojetos e do projeto final do Código Civil cubano de 1987. A primeira versão de 1975 foi uma reprodução do Código Civil Espanhol. No dia 6 de fevereiro de 1979 elaborou-se outra versão, cujo artigo 102 estipulava a responsabilidade por culpa no âmbito

\footnotetext{
${ }^{8}$ O artigo 20 da Constituição de 1940 reconhecia a igualdade dos cubanos ante a lei, não conferindo privilégios para membros da sociedade e declarando ilícita e punível toda discriminação por motivo de sexo, raça, cor e classe e qualquer outra lesiva à dignidade da pessoa humana. (PÉREZ VÉLIZ, 2016, p. 171)

${ }^{9}$ O Código Civil Espanhol foi instaurado em Cuba, Puerto Rico e Filipinas mediante o Real Decreto de 31 de julho de 1889. RAPA ÁLVAREZ, Vicente, "La codificación del Derecho Civil" en Revista Jurídica No. 11 Año IV, abril - junio de 1986, pp. 83-84. In: (PÉREZ GALLARDO, 2000)
} 
contratual, inspirada no artigo 1.101 do Código Civil Espanhol ${ }^{10}$. Esta norma, ainda que não sistematizasse a responsabilidade extracontratual de forma explícita, incluía um capítulo destinado aos direitos inerentes à personalidade, onde reconhecia o direito à integridade física, ao nome, à imagem, a inviolabilidade física, psíquica e moral, à dignidade e honra das pessoas. Impôs, ainda, o dever de respeitar os direitos alheios, denunciando os atos públicos que, sem autorização, violavam a dignidade, a honra e a privacidade, salvo quando tais atos eram necessários por razões de saúde pública, interesse ou seguridade social. No artigo 39 do mesmo preceito, foi consignado o ressarcimento pecuniário pela indenização de danos e prejuízos ao afetado e a transmissão hereditária do direito desta ação. (PÉREZ GALLARDO, 2000, p. 16-18)

Foram realizadas outras versões que não faziam aportes consideráveis na regulação da responsabilidade civil e do dano extrapatrimonial. ${ }^{11}$ Em fevereiro de 1982, foi incluído, pela primeira vez o tema da responsabilidade civil extracontratual em sede de ato jurídico, afiliando-se à teoria subjetiva, mas apenas em relação à responsabilidade civil derivada do delito, na qual foram aplicadas as disposições do Código Penal de 1979, sem fazer menção ao dano moral em sede civil. As novas versões elaboradas a partir de maio de 1986 começaram a tomar forma do projeto do Código Civil atual. Nestas, ficaram reordenados os preceitos dedicados à responsabilidade por ato ilícito. Em dezembro de 1986 foi oferecida a versão final do artigo 38 do Código Civil atual, que se refere aos direitos inerentes à personalidade ${ }^{12}$. Uma vez promulgado o projeto final, configurou-se o Código Civil da República de Cuba, no dia 16 de julho de 1987, e entrou em vigor no dia 12 de abril de 1988. (PÉREZ GALLARDO, 2000, p. 24-26)

${ }^{10}$ Artículo 1101, Trad.: Ficam sujeitos à indenização dos danos e prejuízos causados os que em cumprimento de suas obrigações incorrerem em dolo, negligencia ou morosidade, e os que de qualquer modo contravirem o conteúdo daquelas. (España. Real Decreto de 24 de julio de 1889, Código Civil)

${ }^{11} \mathrm{O}$ dia 22 de agosto do próprio ano emitiu-se outra versão, cujo conteúdo não divergia do anterior, pois, não fazia menção ao ato ilícito nem à disciplina autónoma da responsabilidade extracontratual, baseando-se nos conteúdos da Constituição cubana de 1976. Foram feitas outras versões em fevereiro de 1981; setembro, dezembro e fevereiro de 1985. (PÉREZ GALLARDO, 2000, p. 19-24). Em janeiro de 1983 foi feita outra versão que, em comparação com as anteriores, reduzia a regulação dos direitos inerentes à personalidade, pois só no artigo 39 enunciava alguns destes direitos: direito à integridade pessoal, liberdade, liberdade de consciência, nome, honra, imagem, sem estipular o correspondente ressarcimento de sua vulneração.

12 Artigo 38 do Código Civil Cubano, Trad.: A violação dos direitos inerentes à personalidade consagrados na Constituição, que afete ao patrimônio ou à honra de seu titular, confere a este ou a seus herdeiros a faculdade de exigir: a) o cesse imediato da violação ou a eliminação de seus efeitos, de ser possível; b) a retratação por parte do ofensor; e c) a reparação dos danos e prejuízos causados. 
2.

O Código Civil foi a primeira regulamentação elaborada pelos cubanos para o povo de Cuba, um importante feito duplo, pois o legislador devia conseguir desprender-se da tradição espanhola e elaborar normas que correspondessem ao sistema socialista instituído. Foi o último Código latino-americano do século XX, cuja estrutura afilia-se ao plano alemão de Savigny. (PÉREZ GALLARDO, 2000, p. 27) O mesmo tem sido objeto de muitas críticas diante do seu enfoque sóciopolítico e da técnica legislativa empregada. Há quem o catalogue como uma reforma do Código Civil Espanhol, ${ }^{13}$ que pode ser categorizado como uma ponte entre o direito romano-francês e o direito socialista ${ }^{14}$.

Em relação à regulação do instituto da responsabilidade civil e do dano moral no Código Civil vigente, não se distância muito do tratamento concedido nas normas precedentes ${ }^{15}$. Na lei civil foram unidas as normas relativas às responsabilidades civis: contratual e extracontratual ${ }^{16}$. Sua normativa é muito simples, pois carece de uma enumeração completa dos direitos subjetivos que têm proteção jurídica, sem expressar de forma taxativa outros direitos, cuja defesa tem que ser obtida pela via penal; regula de forma imprecisa o ato ilícito, e não faz menção ao princípio da dignidade humana, só determinando a reparação do dano moral por meio da retratação pública do ofensor, disposição que na prática não cumpre o objetivo pretendido do legislador ${ }^{17}$.

\section{2. Breve caracterização do sistema político, econômico e social existente em Cuba.}

Todo preceito legal responde ao sistema onde se encontra instituído. Sua validade e reconhecimento vão depender do ordenamento jurídico ao qual pertence. Por este motivo, antes de valorar o tratamento concedido ao dano extrapatrimonial em Cuba, é necessário esclarecer, de forma sucinta, alguns

\footnotetext{
13 Assim o entende Luis Díez-Picazo ao referir-se ao Código Civil cubano como uma reforma daquele que havia recebido da Espanha, negando-lhe o caráter de Código Civil de segunda geração. (DÍEZ PICAZO, 1992, p. 481)

${ }^{14}$ Expressão usada por Pierangelo CATALANO, Secretario General de la Associazione di Studi Sociali Latinoamericani (ASSLA) no encontro de estudo sobre "El Código Civil de Cuba y el Derecho Latinoamericano", celebrado em Roma, o dia 20 de novembro de 1990, en II Codice Civile di Cuba..., cit., p. 147. In: (PÉREZ GALLARDO, 2000, p. 40)

${ }^{15}$ Ver no item 2.6.

${ }^{16}$ Artigo 294, Trad.: As normas referentes à responsabilidade civil por atos ilícitos se aplicam, no pertinente, nos casos de incumprimento das obrigações.

${ }^{17}$ Ver nos itens 2.5, p.36 e 2.6 .
} 
2.

aspectos do sistema político, econômico e social existente no país, para que seja possível compreender por que o legislador cubano não demonstrou tanto interesse em regular a proteção desta figura do direito, e por qual razão alguns autores percebem a impossibilidade da reparação econômica do dano extrapatrimonial.

Apesar das inúmeras dificuldades enfrentadas pelo povo cubano para se libertar do colonialismo espanhol, e as contínuas ingerências dos Estados Unidos, o triunfo revolucionário foi exitoso pela tomada das armas no dia 1 de Janeiro de 1959. Posteriormente, foi instaurado um estado socialista no ano de 1961 (MARTÍNEZ HEREDIA, 1988), adotando-se medidas, por parte do governo da ilha, que mudaram os aspectos econômicos, políticos e sociais, caracterizadas pela dominação estatal dos meios fundamentais de produção, dos processos sociais, das relações interpessoais e da conduta individual de todo o povo cubano.

O triunfo dos revolucionários, embora tenha trazido muitas aspirações em matéria de garantias e igualdade social, acabou gerando um ambiente de instabilidade, já que se configurava um novo sistema político, econômico e social, dotado de valores morais diferentes aos que existiam anteriormente, o que possibilitou uma nova compreensão do dano moral e da dignidade humana, ambos conceitos voltados para a preservação do caráter social.

Cuba conduziu muitas mudanças destinadas à obtenção da equidade social, equiparando-se a liberdade com a redistribuição radical da riqueza da comunidade. Essas transformações foram efetivadas através das Leis de Reformas Agrárias, a confiscação, nacionalização e expropriação, por parte do Estado cubano, dos bens pertencentes à classe alta da sociedade, e às empresas e corporações de outros países que operavam na ilha. Tudo isso ocorria paralelamente às campanhas de alfabetização e de aperfeiçoamento dos serviços da saúde (SILVA LEÓN, 2003, p. 10, 25-28). Tais mudanças se destinaram ao fortalecimento do caráter socialista da Revolução; o que foi proclamado no primeiro artigo da Carta Magna, dedicado aos Fundamentos Políticos, Econômicos e Sociais do Estado, a irrevocabilidade do caráter socialista por meio das modificações constitucionais feitas no ano $2002 .{ }^{18}$ (EcuRed).

\footnotetext{
${ }^{18}$ Trad. (...) só no socialismo e no comunismo, quando o homem for liberado de todas as formas de exploração: da escravidão, da servidão e do capitalismo, alcança-se a inteira dignidade do ser humano; e que nossa Revolução elevou a dignidade da pátria e do cubano a superior altura. Artigo 1. Cuba é um Estado socialista de trabalhadores, independente e soberano, organizado com todos e para o bem de todos, como república unitária e democrática, para o desfrute da liberdade política, a
} 
Com o fim de preservar o socialismo da ilha, a Revolução cubana tem se produzido através da mudança do conjunto da vida social, a qual se encontra dirigida e amoldada em correspondência ao interesse estatal, o que é justificado pelo governo cubano em nome da preservação da vida em comunidade, embora sejam vulnerados os aspectos econômicos, políticos, assim como a ideologia individual. (MARTÍNEZ HEREDIA, 1988, p. 98)

O sistema cubano é bem polêmico, sendo louvado por alguns, e ao mesmo tempo, extremamente criticado por outros. Como resultado da profunda inimizade com o governo dos Estados Unidos e os desafios que tem afrontado para resguardar os ideais socialistas, o Estado tem assumido um controle absoluto de todos os elementos que integram o país, desde a implantação das leis, a organização do governo, os meios de comunicação, e até o desenvolvimento do ser humano (Régimen Político), que não é reconhecido de forma individual, senão pelos seus interesses, que estão predestinados em função da comunidade.

Todos os elementos que compõem o sistema giram em torno da sua funcionalidade. Tanto é assim que existe um único partido reconhecido constitucionalmente, não se admitindo de forma livre a oposição ao governo instaurado, nem a liberdade de expressão e de imprensa, direitos que só podem ser exercidos em função dos fins socialistas. ${ }^{19} \mathrm{E}$, além disso, o acesso à informação e à internet é limitado. (EcuRed) (BARRENECHEA, 2015). Exemplos destas limitações podem ser evidenciados no blog Generación $Y$, pertencente à cubana Yoani María Sánchez Cordero, que faz críticas ao governo da ilha (SÁNCHEZ). Não resulta menos certo que este blog também é criticado pelos simpatizantes do governo cubano, e, por sua vez, defendido por aqueles que estão a favor do exercício do direito da liberdade de expressão. O problema não tem sua raiz no

justiça social, o bem-estar individual e coletivo e a solidariedade humana. Artigo 3. (...) O socialismo e o sistema político e social revolucionário estabelecido nesta Constituição, provado por anos de heroica resistência frente às agressões de todo tipo e a guerra econômica dos governos da potência imperialista mais poderosa que tem existido e havendo demonstrado sua capacidade de transformar o país e criar uma sociedade nova e justa, é irrevocável, e Cuba não volverá jamais ao capitalismo. (CUBA, Constitución de la República de Cuba, 24 de febrero de 1976, Preámbulo, art. 1 e 3$)$.

${ }^{19}$ Trad. Artigo 53: Reconhece-se aos cidadãos liberdade de palavra e prensa conforme aos fins da sociedade socialista. As condições materiais para seu exercício estão dadas pelo fato de que a imprensa, a rádio, a televisão, o cinema e outros meios de difusão massiva são de propriedade estatal ou social e não podem ser objeto, em nenhum caso, de propriedade privada, o que assegura seu uso ao serviço exclusivo do povo trabalhador e do interesse da sociedade. A lei regula o exercício destas liberdades. (CUBA, Constitución de la República de Cuba, 24 de febrero de 1976, art. 53) 
2.

fundamento do blog, senão na posição adotada pelo governo de Cuba, que proíbe a divulgação do mesmo, razão pela qual é desconhecido pela maioria dos cubanos.

A partir das características expostas, deriva-se o tratamento dado ao instituto do dano moral no país. Esta figura não é reconhecida de forma constitucional, e a regulação que recebe no Código Civil é muito obsoleta, restringindo-se sua reparação à retração pública do ofensor, disposição que na prática não atende à intenção do legislador. As poucas demandas judiciais sobre o tema influenciam negativamente no não reconhecimento da reparação pecuniária como via eficaz para a compensação dos danos morais.

Outra grande dificuldade é que em Cuba não existe um tribunal de garantias constitucionais. O povo cubano só pode reclamar seus direitos fundamentais se voltando à via civil, que possui uma competência muito limitada. Ainda, conforme o artigo 127 da Constituição, os cidadãos cubanos podem estabelecer seu direito à queixa e petição ante um departamento do Ministerio Público denomindado: Proteção do Direito dos Cidadãos. O Ministério Público é o encarregado de velar pela legalidade, obrigação que lhe vem imposta pela Lei 83 de 1997. (CUBA, Ley No 83, Ley de la Fiscalía General de la República de 11 de julio de 1997, Capítulo III)

Neste procedimento, o Promotor de justiça só se limita a investigar e responder no prazo de 60 días, restabelecendo a legalidade, no caso que se comprove que realmente houve a ofensa aos direitos do demandante e no melhor dos casos, pode solicitar que lhe seja aplicada uma medida ao superior hierárquico infrator dos direitos, ou exercitar a ação penal, no caso em que a lesão tenha o caráter de delito. No entanto, sua disposição não tem caráter vinculante, podendo não ser cumprida, já que, sua força executiva não pode assemelhar-se à que tem uma sentença judicial. O Promotor não pode interpretar e aplicar a lei, nem analisar e conhecer o mérito do assunto, porque esta é uma tarefa judicial, sendo os juízes os encarregados de ministrar justiça. (CONSTITUCIONAL, 2012, p. 4142) (CUBA, Ley No 83, Ley de la Fiscalía General de la República de 11 de julio de 1997, arts. 75 r, s; 90 ñ, o; 98 i,m; 105 j; 106 d).

Desta forma, evidencia-se a carência de proteção individual por parte do Estado cubano, trazendo como resultado, a inexistência de reparação pecuniária legalmente reconhecida. No sistema cubano tanto a pessoa natural como os funcionários do Estado que, no seu exercício, provocam um dano moral, não 
2.

respondem pelas consequências de seus atos. Cuba é um país socialista, e talvez por este motivo o legislador cubano, e parte da doutrina existente, reconhecem que o dano extrapatrimonial, propriamente dito, não permite a reparação econômica, pois neste tipo de sistema, no qual a coletividade é o elemento primordial a ser protegido, a reparação não pode se assemelhar ao ser social com seu possível enriquecimento, justificado em um suposto dano moral.

No entanto, esta crença não pode figurar como um limitador para a plena reparação do dano extrapatrimonial, não apenas em relação à reparação pecuniária, mas todas as vias possíveis para colocar a vítima no lugar em que se encontrava antes da provocação do detrimento. Mesmo que seus direitos não possam ser restituídos, devem ser ao menos reparados, por meio da compensação pecuniária e a retratação pública, devendo todos os membros da sociedade, inclusive o Estado, responder pela violação dos direitos fundamentais.

O tipo de sistema instituído em Cuba não pode justificar a carência de leis que concedam solução prática a normas vagas ou a vazios legais. É nesta situação que o dano moral se encontra. Sua identificação e aplicação no sistema legal cubano deixa muito a desejar, sobretudo em relação à proteção da dignidade da pessoa humana como premissa do Estado cubano. Isto é evidenciado pela prática judicial do país, em que há uma crescente vulneração da proteção dos interesses existenciais do ser humano, conforme serão demostradas a seguir ${ }^{20}$.

\section{3. Conceito do dano moral na doutrina cubana e estrangeira. Necessidade da sua redefinição.}

As dificuldades em relação à comprovação do dano, concretamente o dano moral, são derivadas da sua própria definição. Professores do direito civil cubano alegam que o dano comprova-se na diferença existente entre a situação da vítima antes de sofrer esse ato lesivo, e a sua situação posterior. Esta diferença pode traduzir-se na esfera patrimonial da pessoa (dano material), ou ter incidência na situação anímica, psíquica, que pode ou não ter repercussões patrimoniais (dano moral). (PÉREZ GALLARDO, RODRÍGUEZ OJEDA, et al., 1999, p. 60) (VALDÉS DÍAZ, PÉREZ GALLARDO, et al., 2000, p. 318) Por dano entende-se

\footnotetext{
${ }^{20}$ Ver no item 2.7.
} 
2.

toda situação de desvantagem em que é colocada a vítima, como consequência da lesão de seus direitos. (OJEDA RODRÍGUEZ e TERESA, 2000, p. 157)

Segundo o professor Antonio Díaz Pairó, o dano se configura na lesão de um interesse legítimo, encontrando-se na diferença da situação do lesado antes e depois de suportar o dano (DÍAZ PAIRÓ, 1997, p. 61). Através deste entendimento, concebem-se os termos: dano emergente e lucro cessante. $\mathrm{O}$ dano emergente é a diminuição dos valores patrimoniais que a vítima experimentou como consequência do fato danoso, e o lucro cessante são aqueles benefícios que a vítima poderia ter recebido se o dano não tivesse acontecido; são as implicações futuras de um dano presente. (OJEDA RODRÍGUEZ e TERESA, 2000, p. 94).

Por outra parte, o termo moral faz alusão àqueles aspectos inerentes ao ser humano individual, elementos que não se exteriorizam, já que existem apenas na psique da pessoa, condicionado pelos diferentes aspectos do meio social no qual aquela se desenvolve. Por isso, o que para alguns pode ser moralmente reprovável, para outros é compreendido como um ato completamente normal. Para efeitos do tema em estudo, a moral estaria vinculada aos direitos inerentes, inalienáveis, imprescritíveis, perpétuos do ser humano, que conformam a sua dignidade humana. O termo moral, além de ser sumamente debatido, é eticamente permissível na coletividade, e se constitui como um conjunto de elementos psíquicos e espirituais que incidem no desenvolvimento normal do indivíduo.

Escritores estrangeiros, que têm relevância na doutrina cubana e na prática judicial, concebem a ideia de que o dano moral incide nos sentimentos, sofrimento ou dor que padece uma pessoa, insuscetível de apreciação pecuniária. (LLAMBIAS, BENEGAS RAFFO e SASSOT, 1997, p. 102). Estes centram sua análise na própria diferença entre o dano moral e o patrimonial, entendendo que o dano patrimonial é aquele suscetível de apreciação pecuniária, enquanto o dano extrapatrimonial é uma lesão nos sentimentos da vítima, traduzidos em padecimentos físicos, dor etc., que não podem ser considerados economicamente.

Outros estudiosos estrangeiros da matéria negam-se a situar o dano moral somente nos sofrimentos injustamente ocasionados, senão que entendem a incidência desse dano em alguns bens do indivíduo, como a saúde, liberdade, honra etc. Distinguem, assim, os danos morais que atacam a parte social do 
2.

patrimônio moral ${ }^{21}$, ou seja, sua honra e consideração daqueles danos morais que incidem na esfera afetiva do patrimônio moral, e que se traduzem em dor, sofrimento, etc.. Na primeira tipologia de danos, podem estar unidos a um prejuízo de caráter patrimonial, entretanto a segunda geralmente não está acompanhada de um prejuízo econômico. (ALVAREZ VIGARAY, 1966).

Autores partidários desta posição doutrinária ponderam os casos em que a pessoa que tolerou a lesão viu-se privada de desfrutar certos benefícios que a vida confere, como por exemplo: ouvir música, praticar esportes, etc., tudo o que implica uma frustração no desenvolvimento pleno da vida. (BORDA, 1998, p. 168). Este próprio autor, de forma acertada, chama a atenção em relação à necessidade de distinguir o dano moral puro e suas consequências econômicas, pois existem casos em que danos patrimoniais são causados pelo mesmo ato que provocou o dano moral ou vice-versa, havendo a necessidade de indenizar ambos de forma independente. Isso não exige a interposição de dois processos judiciais, senão que, nesses casos, devem-se ressarcir todos os danos padecidos com base no princípio da reparação integral da vítima. (BORDA, 1998, p. 169)

Há quem inicie a análise na própria conduta do ofensor, configurando-se o dano quando o agente age com malícia e com intenção de ocasionar um resultado prejudicial. (LLAMBIAS, BENEGAS RAFFO e SASSOT, 1997, p. 112). Esta consideração é suscetível de crítica, já que o referido autor analisa apenas a conduta do lesante, e não o dano ocasionado, devendo-se, pelo contrário, determinar a magnitude da lesão, que pode ter um resultado maior, embora o agente agisse sem culpa. Nesse caso, não haverá o ressarcimento integral da vítima, que terá que provar a culpa da contraparte para poder obter a correspondente compensação, embora o dano suportado tenha sido produto de uma conduta imprudente, involuntária etc..

A jurisprudência, por sua parte, não adota uma iniciativa para mudar a concepção arcaica que concebe o dano moral como uma dor insuscetível de reparação econômica. Este entendimento é demonstrado na decisão emitida pela Sala Segunda Civil do Tribunal Provincial Popular da Havana, na sua sentença ${ }^{\circ}$ 110 de 2 de novembro de 1999, juiz principal Díaz Tenreiro:

\footnotetext{
${ }^{21} \mathrm{O}$ termo patrimônio moral atualmente não é usado em Cuba, mas, no antigo Código de Defesa Social se fazia alusão a este vocábulo para referir-se aos interesses existenciais das pessoas.
} 
“(...) aun cuando no existe una expresa definición legislativa con respecto al daño moral, de los términos de esta materia cabe aceptar lo que la doctrina de modo mayoritario estima como "la afectación que una persona sufre en sus sentimientos, afectos, creencias, decoro, honra, reputación, vida privada, configuración y aspecto físico, o bien en la consideración que de sí misma tienen los demás; y habrá que presumir que se produjo este daño moral, cuando se vulnere o menoscabe ilegítimamente la libertad o la integridad física o psíquica de las mismas", habida cuenta de que si la persona, a diferencia del resto de los seres vivos, tiene capacidad para sentir el dolor en presente, que no es otra cosa que la manifestación puntual de la lesión, en pasado, como recuerdo de aquella, y en futuro, como miedo a que se repita la situación dolorosa, todo ello como consecuencia de la capacidad humana para memorizar los actos y situaciones". ${ }^{22}$

Posição reafirmada pelo Tribunal Superior de Justiça, Sala do Civil e do Administrativo, na sua sentença No 697 de 9 de novembro de 2002, juiz principal Carrasco Casi:

“(...) el daño moral (...) no es otra cosa que la lesión de los bienes o derechos que pertenecen al ámbito personal del sujeto de derecho, y que repercute de alguna manera en sus intereses de índole afectiva y emocional (...) para que este daño sea estimado con relevancia jurídica, debe producir un perjuicio, una pérdida o menoscabo y también debe incidir sobre un bien jurídico de la persona y ser susceptible de resarcimiento en concepto de responsabilidad civil (...)". Cuando se produce un daño moral el derecho al resarcimiento debe operar con características peculiares, ya que no existe correspondencia entre los bienes lesionados (personales o extrapatrimoniales) y el dinero, como bien utilizado para el resarcimiento. Debe precisarse cuál es la finalidad de la indemnización en estos casos. $^{23}$

Para alguns o dano moral encontra-se na transgressão dos direitos inerentes à personalidade da vítima. O situam naqueles prejuízos de caráter não patrimonial que invalidam ou incapacitam o lesado, ocasionando, como consequência, um sofrimento. (OJEDA RODRÍGUEZ e TERESA, 2000, p. 89 e 95). Uma parte

${ }^{22}$ Trad.: (...) embora não exista uma expressa definição legislativa com relação ao dano moral, dos termos desta matéria pode-se aceitar o que a doutrina de modo majoritário estima como "a afetação que uma pessoa sofre em seus sentimentos, afetos, crenças, decoro, honra, reputação, vida privada, configuração e aspecto físico, ou bem na consideração que de si mesma têm os demais; e haverá que presumir que se produziu este dano moral quando se vulnere ou prejudique ilegitimamente a liberdade ou a integridade física ou psíquica das mesmas”, já que, se a pessoa, a diferença do resto dos seres vivos, tem a capacidade para sentir a dor em presente, que não é outra coisa que a manifestação pontual da lesão, em passado, como lembrança daquela, e em futuro, como medo a que se repita a situação dolorosa, tudo isso como consequência da capacidade humana para memorizar atos e situações.

23 Trad. "(...) o dano moral (...) não é outra coisa que a lesão dos bens ou direitos que pertencem ao âmbito pessoal do sujeito do direito, e que repercute de alguma forma em seus interesses de índole afetiva e emocional (...) para que este dano seja estimado com relevância jurídica, deve produzir um prejuízo, uma perda ou detrimento e também deve incidir sobre um bem jurídico da pessoa e ser suscetível de ressarcimento em conceito de responsabilidade civil (...)". Quando se produz um dano moral o direito ao ressarcimento deve operar com características peculiares, já que não existe correspondência entre os bens lesados (pessoais ou extrapatrimoniais) e o dinheiro, como bem utilizado para o ressarcimento. Deve precisar-se qual é a finalidade da indenização nestes casos. 
2.

vanguardista da doutrina cubana o define como o prejuízo sofrido na psique de uma pessoa, transgressão de seus direitos personalíssimos por meio do detrimento à dignidade, honra, integridade física, privacidade ou qualquer elemento que incida negativamente na sua normalidade, assim como todos os padecimentos desenvolvidos pela vítima por causa deste detrimento. (VEGA CARDONA e ORDELÍN FONT, 2012, p. 290).

A doutrina cubana continua insistindo na reparação completa do dano moral, situando o reconhecimento da dignidade como a primeira consequência da existência da pessoa. (VALDÉS DÍAZ, PÉREZ GALLARDO, et al., 2000, p. 111). Por meio da proteção dos direitos subjetivos pretendem justificar a reparação do dano moral. Estes direitos são os que enunciam o consequente dever jurídico quando ocorre sua vulneração. O professor Albaladejo os define como a situação de um poder jurídico que encontra proteção no sistema legal, composta por faculdades atribuídas a seu titular para a satisfação de interesses considerados de forma abstrata, deixando ao arbítrio deste seu exercício e sua defesa. (ALBALADEJO, 1996, p. 440) Na doutrina cubana são direitos subjetivos: os direitos da personalidade; os direitos pessoais de família e os direitos patrimoniais (VALDÉS DÍAZ, PÉREZ GALLARDO, et al., 2000, p. 117).

Sob a valoração do princípio constitucional da dignidade humana, justificase o conceito de dano extrapatrimonial como transgressão dos direitos inerentes à existência mesma do ser humano, entre os que se encontram: o direito à vida, à integridade física e psíquica, à liberdade, ao nome, à intimidade, à imagem, etc.; mas, também possibilita-se o ressarcimento do lesado da forma mais abrangente possível. Justamente, o reconhecimento do próprio indivíduo parte da consagração da sua dignidade (LARENZ, 1978), ficando este facultado em exigir uma obrigação civil específica à pessoa que desrespeite esse princípio fundamental. Desta forma, configura-se o dano moral ante a afronta injusta dos componentes da dignidade da pessoa humana, naqueles casos em que se demonstre um exercício arbitrário ou desmedido do direito, que provoque um agravo na esfera existencial do lesado (BODIN DE MORAES, 2003, p. 179). Por todos estes elementos, exige-se a redefinição do dano moral no ordenamento jurídico cubano para garantir a inteira reparação da vítima do prejuízo ocasionado de forma injusta. 
2.

\section{4. \\ Critérios para a qualificação do Dano Moral. Necessidade da configuração do ato injusto.}

A concepção da responsabilidade civil tem mudado conjuntamente com a demanda da sociedade, em especial, em relação aos atos lesivos que causam prejuízos aos aspectos essenciais que compõem a dignidade da pessoa. Entender que só o ato ilícito é capaz de causar dano acaba por deixar inúmeros casos sem tutela jurídica, os quais, embora estejam conforme à lei, podem gerar um dano que exige uma reparação. (FEDERICO DE LORENZO, p. 15)

Em Cuba, esta mudança ainda não está concebida como via legítima do direito, pois, continua-se vinculando o caráter ressarcitório dos danos através do ato ilícito, configurando-se a lesão sempre que se atue em contraposição a uma norma. No entanto, este entendimento não encontra equivalência com a dinâmica do mundo atual evoluído, tampouco com as disposições previstas em outros ordenamentos. Justamente, o novo direito de danos está configurado a partir do prejuízo sofrido injustamente, independentemente da conduta de quem é o seu causador. Esta concepção surgiu com a necessidade da sociedade pós-industrial e a exigência de ponderar a cláusula geral do alterum non laedere (FEDERICO DE LORENZO, p. 47) como critério de proteção da convivência humana.

A antiga concepção do ato ilícito, que ainda é adotada em Cuba, faz com que, quando há um abuso do direito, cuja prática é comum, principalmente por funcionários do Estado, as vítimas desses atos danosos ficam sem proteção, diante do não reconhecimento do dano injusto como motivador da responsabilidade civil. Não basta que as pessoas exerçam livremente seus direitos, também se deve ter em consideração que essa liberdade não repercuta no direito alheio sem justificação. A regulação do dano injusto pode-se apreciar no Código Civil da Itália no seu artigo 2043 (FEDERICO DE LORENZO, p. 50), configura-se quando há um comportamento que lesiona um interesse especificamente protegido pelo ordenamento legal. Isso significa que esse interesse demanda tal proteção e respeito, que uma vez transgredido deve haver irremediavelmente uma reparação integral do lesado. Não existe o dever de não causar dano, mas estamos todos obrigados a não causar um dano injusto (FEDERICO DE LORENZO, p. 64).

$\mathrm{O}$ ato ilícito pressupõe a violação de qualquer norma legal que exista no sistema jurídico, e não oferece uma solução para a vítima desses detrimentos, 
2.

senão que procura um castigo para quem agiu de forma culposa. Esta concepção resta ultrapassada pelas exigências sociais, ante a necessidade de se obter a correspondente reparação em razão de um dano injusto causado aos seus direitos, por meio do exercício abusivo ou injusto de outra pessoa.

Caracteriza-se o dano injusto através do dever fundamental do alterum non laedere, não sendo levada em consideração a visão voluntarista do comportamento contra jus de uma pessoa. Dano injusto seria o dano provocado sem uma justificativa, suficientemente convincente, que impeça que a vítima tolere as consequências desse ato de forma individual. Ainda que decorrente de conduta lícita, a injustiça do dano é configurada quando este incide negativamente nos elementos da dignidade da pessoa humana. Uma vez valorados, os interesses ou direitos que são sopesados indicam ser irrazoável que a pessoa lesada fique irressarcida. (BODIN DE MORAES, 2003, p. 179)

Desta forma, alguns danos que acontecem no dia a dia podem ser justificados, pois as relações humanas tendem a levar consigo a ocorrência de prejuízos de toda índole. Existem prejuízos que devem ser tolerados pela pessoa afetada (BODIN DE MORAES, 2003, p. 175), embora the provoquem detrimentos, estes são justificáveis e lícitos, ao contrário dos chamados danos injustos, cuja reparação é iniludível. A lesão produzida seria justificada, não por falta de proibição do comportamento que o ocasionou, senão porque o interesse do lesante, comparado com o do lesado, merece ser priorizado ou sobreposto. (FEDERICO DE LORENZO, p. 79)

Uma vez valorados todos estes elementos indicam a necessidade de uma mudança na concepção do dano moral no sistema legal de Cuba. Esta modificação deve se iniciar pela sua definição e qualificação, entendendo-se que os elementos que devem configurar a responsabilidade civil são o dano, a culpa, o risco e o nexo causal. Trata-se da valoração de um dano contrário à lei, mas também de um dano derivado do exercício de um direito de forma abusiva e injusta.

O dano moral também não deve ser considerado a partir da afetação da dor, aquele deve evidenciar-se pela vulneração dos direitos inerentes ao indivíduo, que conformam a sua dignidade. Ou seja, para que se configure um dano moral o princípio da dignidade da pessoa humana deve ser transgredido por um ato que não encontra justificativa de acordo com a boa-fé, que deve caracterizar toda relação humana. Justamente no princípio da dignidade da pessoa humana está 
fundamentado o dano moral, que uma vez identificado, deve haver a sua inteira reparação, devendo serem adotadas todas as vias pertinentes que permitem a compensação do lesado, sendo este o principal objetivo do direito de danos.

\section{5. \\ Discussão acerca da reparação pecuniária do dano moral. Necessidade de seu reconhecimento.}

Como anteriormente foi expressado, o órgão judicial nega a reparação econômica da vítima de um dano moral. Esta situação já foi resolvida pela maioria dos ordenamentos pertencentes ao sistema romano-germânico, porém, em Cuba, ainda não se estabeleceu um critério único, pois não existe uma decisão judicial que tenha concedido a reparação econômica por um dano moral puro.

Em matéria de responsabilidade civil, o problema da reparação do dano moral está no centro de atenção da doutrina, do legislador, e dos intérpretes da lei. Lograr que a vítima do ato ilícito, ou injusto, possa sentir-se ressarcida pelos danos sofridos, é o objetivo do moderno direito de danos. Esta pretensão, em ocasiões, é difícil de alcançar, pois depende da interpretação, regulação e atenção que em cada sistema é concedida a esta figura jurídica. Nos ordenamentos com tradição romano-germânica, em relação aos países da common law, reconhecer o ressarcimento pecuniário do dano moral tem sido uma tarefa árdua e paulatina. Porém, isso não significa que seja impossível, já que existem países, como é o caso do Brasil, onde esta possibilidade desfruta de amparo civil-constitucional.

Para justificar a necessidade da reparação do dano extrapatrimonial em Cuba, resulta suficiente a interpretação do princípio constitucional que guia a sociedade cubana e que resulta o objetivo fundamental da revolução: "Yo quiero que la ley primera de nuestra República sea el culto de los cubanos a la dignidad plena del hombre" ${ }^{24}$. Esta disposição representa não apenas um princípio fundamental, senão a principal tarefa do Estado cubano, ${ }^{25}$ que se encontra obrigado a garantir a dignidade plena de todos os membros da sociedade por meio

\footnotetext{
${ }^{24}$ Eu quero que a lei primeira de nossa República seja o culto dos cubanos à dignidade plena do homem. (CUBA, Constitución de la República de Cuba, 24 de febrero de 1976, Preámbulo e art. 1) ${ }^{25}$ Artigo 9. a) O Estado realiza a vontade do povo trabalhador e (...) garante a liberdade e a dignidade plena do homem, o desfrute de seus direitos, o exercício e cumprimento de seus deveres e o desenvolvimento integral de sua personalidade. (CUBA, Constitución de la República de Cuba, 24 de febrero de 1976, art. 9 a)
} 
da realização da justiça social, bem-estar individual e coletivo, e solidariedade humana. Desta forma, não encontram justificativas as posições que negam ou limitam a tutela que deve ser concedida a toda pessoa, ante a lesão de sua dignidade, adotando-se todas as medidas necessárias que possibilitem sua reinserção no estado em que se encontrava antes de sofrer o detrimento.

Como antes foi explicado, parte da doutrina cubana justifica o não ressarcimento do dano extrapatrimonial na distinção entre os direitos subjetivos patrimonais e não patrimonais. Expõem que os primeiros são suscetíveis de valoração econômica, enquanto os segundos satisfazem pretensões de índole moral ou espiritual, que não são mensuráveis em pecúnia (VALDÉS DÍAZ, PÉREZ GALLARDO, et al., 2000, p. 175). Esta é uma concepção errônea, pois no caso dos danos não patrimoniais, não se está colocando valor ao direito atingido, senão na reparação pecuniária, que pode atenuar o prejuízo causado. Devemos lembrar que a reparação do dano moral é puramente compensatória, e compensar é dar algo ou fazer alguma coisa em benefício de alguém, como forma de enfraquecer o dano causado. (COMPENSAR, 2017).

Nestes casos, o dinheiro não vai substituir a moral do indivíduo, senão que vai ser utilizado como um amenizador ante uma situação em que quase nunca se poderá reverter o dano, pelo menos nas situações em que estejam envolvidos elementos que incidem negativamente na esfera existencial da pessoa. $\mathrm{O}$ dinheiro atua como medida de valor, instrumento de cambio ou como meio de pago. (PÉREZ GALLARDO, RODRÍGUEZ OJEDA, et al., 1999, p. 25). Cumpre uma função satisfatória ao ser um bem fungível, utilizado como troca na relação jurídica e esgotando sua função valorativa na compensação. É uma via que se tem mostrado eficaz para reparar o dano moral. No entanto, isso não significa que não existam outras formas, igualmente idôneas, pelas quais pode ser concedido o ressarcimento $^{26}$. Entretanto, a reparação monetária resulta uma via insuficiente, muito maior resulta a injustiça de deixar a vítima de um dano sem reparação

\footnotetext{
${ }^{26}$ Ver no capítulo 4 dedicado às propostas concedidas para uma melhor interpretação e aplicação do dano moral. Aqui são concedidas outras vias pelas quais pode ser reparado o dano moral, tal e como a retratação pública, vista sua funcionalidade a partir da regulação do direito de resposta constitucionalmente estipulado no Brasil; igualmente a possibilidade da adoção de seguro e a instituição da seguridade social como vias eficazes na reparação solidária do dano moral, etc.
} 
2.

alguma. O princípio da reparação integral no direito moderno exige a reparabilidade do dano moral. (BORDA, 1998, p. 169)

Resulta certo que o dinheiro, algumas vezes, pode desvirtuar a natureza da ação judicial que pleiteia o dano moral, já que em determinadas ocasiões a dor que dizem ter as partes é mera especulação, que só tem por finalidade a obtenção de um benefício econômico. Aliás, esta consideração ficaria esquecida se fossem valorados de forma correta a definição do dano moral, os elementos da responsabilidade civil, sobretudo a imposição do quantum indenizatório, cuja função não é enriquecer à vítima do prejuízo. Sempre que exista um dano injusto que atente contra a dignidade humana deve conceder-se amparo judicial, porém se o dano moral continuar sendo comparado com as suas possíveis consequências (dor, sofrimento, etc.) a reparação não será exercida de forma efetiva.

No caso do dano patrimonial a indenização se mede pela soma dos valores pecuniários que se equiparam ao prejuízo sofrido, porém para o dano moral não é possível aplicar o mesmo juízo, já que, não é atingido o patrimônio do lesado. (LLAMBIAS, BENEGAS RAFFO e SASSOT, 1997, p. 110). Este autor percebe o perigo da reparação do dano moral justificado no sofrimento, já que nestes casos se ressarcirá toda pessoa que sofra um dano de forma direta e indireta. Não obstante, reconhece a necessidade de reparar o dano moral diante do imperativo de justiça, que ficaria vulnerável se o lesado não fosse restituído ao estado anterior à lesão (LLAMBIAS, BENEGAS RAFFO e SASSOT, 1997, p. 102 e 112).

Por outra parte, há alguns autores que entendem que o dano moral é suscetível de reparação, mas não de ressarcimento. Expõem que ressarcir é abarcar um vazio patrimonial, e que, por sua vez, a reparação encontra um patrimônio sem afetação, o qual é aumentado para que seu titular possa encontrar uma compensação à sua dor. (ALVAREZ VIGARAY, 1966, p. 91 e 97). Nesses casos, a reparação vai depender da forma em que o direito será exercido pelo lesante, pois só será indenizável o dano extrapatrimonial produzido em virtude do abuso de um direito, distinguindo o exercício normal daquele malicioso. (ALVAREZ VIGARAY, 1966, p. 103)

Outros autores manifestam a impossibilidade de que o juiz valore pecuniariamente a dor. Argumentam que as sentenças que considerassem a 
2.

reparação econômica, seriam injustas, arbitrárias e até ridículas; pois não existe equivalência entre o bem atingido e a entrega de uma soma monetária, concepção pela que se agiria a partir de uma filosofia moral errônea. Alguns autores da doutrina dos países da Europa do Leste ${ }^{27}$ percebem o caráter mercantilista desta possibilidade, por seu antagonismo com a moral socialista, manifestando que a reparação pecuniária de danos morais é uma humilhação àquele que o sofre.

Através do critério referente ao caráter mercantilista da reparação pecuniária, pode-se perceber a diferença que existe entre Cuba e o Brasil em relação à adoção da reparação pecuniária do dano moral. Consegue-se situar as diferenças entre ambos os países pelo próprio sistema adotado por eles, já que no caso do Brasil, existe um sistema econômico capitalista, com diferenças de classes, propriedade privada, relação de consumo, entre outros elementos distintivos dessa situação mercantilista, não traz exceção a este sistema em relação ao tratamento dado ao dano moral, como se verá na valoração das decisões resolvidas pelo TJRJ, cujas sentenças proferem quantias monetárias excessivas fundamentadas na figura do caráter punitivo ${ }^{28}$. Ao contrário, em Cuba, encontrase um sistema completamente diferente, com ausência de todos estes elementos, já que, como exposto, o sistema é socialista, caracterizado pela igualdade econômica social $^{29}$, inexistência de classes sociais, na qual se encontra assegurado o acesso à educação, saúde, esporte, trabalho sem distinção de raça, sexo e de forma gratuita.

Por todos estes elementos, há quem justifique a desproteção que hoje em dia tem a vítima de um dano moral em Cuba, mas essa afirmação além de injusta contradiz o próprio sistema socialista instituído, no qual o homem deve figurar como o principal expoente a ser tutelado. A sociedade e o Estado, de forma geral,

\footnotetext{
${ }^{27}$ FRIDIEV, afirma que a reparação do prejuízo moral é o resultado do espírito burguês que aprecia tudo em dinheiro (FrIDIEV."La responsabilidad civil en el Derecho soviético", Revista Internacional de Derecho comparado, 1985, p. 754.) De igual forma IONESCU quem afirma que a reparação do dano moral é incompatível com a moral socialista. (IONESCU, Traian, "La reparación del daño moral en el Derecho socialista rumano", en La Responsabilidad civil en los Estados del Este, Bruselas, 1967, p. 27). Mozolin e KULAGUIN qualificam a reparação pecuniária como contrária à ideia da dignidade humana e humilhante moralmente para o que sofre o dano (Mozolin, V.P. y Kulaguin, M.I., El Derecho civil y comercial de los países capitalistas, traducción de Noel Chaviano SaldaÑa, Pueblo y Educación, La Habana, 1988, p. 227.) In: (RODRÍGUEZ CORRÍA, 2003)

${ }^{28}$ Ver no item 3.6.

${ }^{29}$ Trad. Artigo 14. Na república de Cuba rege o sistema de economia baseado na propriedade socialista de todo o povo sobre os meios fundamentais de produção e na supressão da exploração do homem pelo homem. Também rege o princípio de distribuição socialista "de cada qual segundo sua capacidade, a cada qual segundo seu trabalho". A lei estabelece as regulações que garantem o efetivo cumprimento deste princípio.
} 
2.

estão obrigados a responder ante um dano moral cometido de forma injusta. No caso de Cuba a sua reparação limita-se à retratação pública do ofensor, ou seja, resulta em uma desculpa pública feita pelo ofensor ao ofendido. Aqui a reparação do dano moral não é dirigida à reintegração de um patrimônio, senão à proporção, na medida do humanamente possível, explicação que na prática não ocorre.

A retratação pública não resulta vinculante na prática judicial, sendo escassa sua aplicabilidade. $\mathrm{O}$ acesso à justiça não é gratuito, e, consequentemente, para que a vítima requira seu ressarcimento deve arcar com o pagamento dos honorários de um advogado, sendo possível obter a desculpa pública do ofensor, mas, por outro lado, acarreta em um prejuízo econômico diante do próprio ajuizamento da ação. Se bem é certo que cada parte da lide pode solicitar que a parte contrária arque com os honorários advocatícios e demais gastos do processo; esta é uma decisão discricionária do juiz, pois nem sempre que o demandante é favorecido pela sentença, impõe-se à contraparte o pago destes honorários. ${ }^{30}$

Por isso, afirma-se a necessidade de incrementar um caráter econômico na reparação do dano moral, utilizando-se bens patrimonais para satisfazer necessidades morais, sendo melhor garantir uma má reparação do que um desamparo total. Má reparação no sentido de que nenhuma quantidade de dinheiro poderá substituir o direito abrangido, nestes casos, o dinheiro não vai conseguer que a pessoa esqueça o prejuízo suportado ou recupere a sua dignidade, pois, o direito existencial violado não tem valor pecuniário algúm, mas, pelas próprias funções do dinheiro e a necessidade de reparar à vítima do prejuízo, resulta mais justa a reparação pecuniária, apesar de não ser a ideal, do que a total desproteção da vítima desse detrimento. No caso de Cuba, a implementação da reparação econômica teria uma função adequada, pois, os salários são relativamente proporcionais, e, por consequência, ante uma reparação por dano moral, ninguém irá receber uma quantia superior ao nível de vida instaurado de forma geral na sociedade. Aqui, a finalidade do processo será atingida através do ressarcimento da vítima, que será melhor considerada e valorada por seu Estado e sociedade.

Essas considerações estão superadas por outras doutrinas que entendem a reparação do dano moral como uma necessidade social, especificamente de

\footnotetext{
${ }^{30}$ Ver nos artigos 198 ao 212 da Ley No 7, Ley de Procedimiento Civil, Administrativo, Laboral y Económico de 19 de agosto de 1977.
} 
2.

consagração da dignidade humana. O certo é que Cuba ficou sob a análise arcaica da jurisprudência espanhola que regeu na ilha, a que sempre negou o ressarcimento do dano moral. Aliás, através da sentença do dia 6 de dezembro de 1912 reconheceu a reparação pecuniária em um caso de lesão à honra de uma mulher (OJEDA RODRÍGUEZ e TERESA, 2000, p. 95). Posteriormente, com as sentenças do Tribunal Superior do dia 26 de setembro de 1925 e de 26 de maio de 1936 admitiu-se o ressarcimento do dano moral em Cuba, mas só quando o prejuízo tenha consequências patrimoniais, não se reparando o dano moral puro. (PÉREZ GALLARDO, RODRÍGUEZ OJEDA, et al., 1999, p. 60) Critério que o sistema judicial cubano tem seguido até nossos dias.

Pelo exposto, resta evidente que a reparação pecuniária do dano moral, não se verifica na legislação, nem na prática judicial cubana, o que se traduz em um total desamparo dos interesses inerentes à dignidade da pessoa, enaltecidos pelo Estado cubano. A exigência de um dano patrimonial como condição para que exista uma hipotética reparação do dano moral é negar valor à figura ora analisada. A concessão da proteção legal apenas ao dano patrimonial reforça este argumento. Portanto, tal postura diante do dano moral não é justificável, especialmente pela origem dos termos e funções que a reparação de danos representa na sociedade (BITTAR, 1994, p. 80), sobretudo, num Estado socialista.

Pode-se afirmar que, seu tratamento, distancia-se muito em relação à regulação existente no sistema brasileiro. Cuba pertence aos sistemas fechados, cujo tratamento do dano extrapatrimonial vem especificado na lei, limitando-se, em tese, a atuação do juiz às regras contidas no Código Civil. Porém, devem ser levados em consideração os preceitos do texto supremo de Cuba, cujas cláusulas legais passaram ao esquecimento por parte dos intérpretes do direito, sendo necessário retomar sua imediata utilização, como fundamento de direito válido para argumentar qualquer litígio que envolva um pedido de compensação do dano moral. Parte da doutrina cubana demanda a reparação integral da vítima, que deve ser exercida por meio da compensação por livre apreciação do juiz, finalidade que pode alcançar-se através da reparação em dinheiro, a eliminação da fonte da qual nasceu o dano, e a retratação pública do ofensor. (RODRÍGUEZ CORRÍA, 2003) (VALDÉS DÍAZ, PÉREZ GALLARDO, et al., 2000, p. 320) 


\section{6. \\ Exame do dano extrapatrimonial no sistema legal cubano. Especial referência ao Código Civil}

Como antecipadamente explicado, o dano moral surge com a lesão dos fundamentos da dignidade humana. Na norma suprema, não se faz menção ao dano moral, mas, no seu artigo 26 concede à vítima de um dano proveniente da atuação dos funcionários públicos do Estado, o direito de reclamar e obter a correspondente reparação, sem especificar a forma em que será ressarcida ${ }^{31}$. Salvo tal hipótese, não existe em nossa norma superior hierárquica artigo dedicado a este tema de tão importante consagração. Por consequência, deposita-se no Código Civil a responsabilidade de consignar e delimitar aquilo que o legislador esqueceu-se de inserir na lei suprema.

A lei substantiva está caracterizada pela insuficiência de suas normas. No seu artigo $8^{32}$ estabelece o caráter suplementar do código em relação às leis que formam parte do próprio ordenamento, encarregadas de abordar aqueles conteúdos que apresentam um tratamento deficiente na norma substantiva. Podese entender que o legislador tentou equiparar, de alguma forma, alguns aspectos que haviam sido tratados no Código Civil de forma concisa ou inacabada, evitando a possibilidade de que outras leis suprissem essa ausência normativa. Por isso, o Código Civil é consultado quando não existem outras disposições especiais que regulem a questão que se precise conhecer (PÉREZ GALLARDO, 2007). Embora a regulação do dano moral encontre grande deficiência, nenhuma outra lei ficou encarregada do seu aperfeiçoamento, o que ocasionou um retrocesso considerável em relação à sua interpretação e aplicação em sede judicial, podendo-se afirmar que seu tratamento é arcaico e incoerente.

A lei substantiva começa a regulação do instituto em estudo a partir dos atos ilícitos, só prevendo a responsabilidade civil pela comissão de um dano ou prejuízo $^{33}$. Desta forma, o Código oferece uma definição imprecisa do ato ilícito, pois este vocábulo não só compreende a produção de um dano ou prejuízo a

31 Trad. Artigo 26. Toda pessoa que sofrer dano ou prejuízo causado indevidamente por funcionários ou agentes do Estado com motivo do exercício das funções próprias de seus cargos, tem direito a reclamar e obter a correspondente reparação ou indenização na forma que estabelece a lei. (CUBA, Constitución de la República de Cuba, de 24 de febrero de 1976)

${ }^{32}$ Trad. Artigo 8. As disposições deste Código são supletórias com relação a matérias civis e outras reguladas em leis especiais. (CUBA, Ley No 59, de 16 de Julio de 1987. Código Civil)

${ }^{33}$ Trad. Artigo 81. Os atos ilícitos são fatos que causam dano ou prejuízo a outro. (CUBA, Ley $\mathrm{N}^{\circ}$ 59, de 16 de Julio de 1987. Código Civil) 
terceiros, senão que implica a vulneração de uma norma jurídica concreta ou atenta contra o dever genérico alterum non laedere. (VALDÉS DÍAZ, PÉREZ GALLARDO, et al., 2000, p. 300) (PÉREZ GALLARDO, RODRÍGUEZ OJEDA, et al., 1999, p. 303)

Os atos ilícitos se dividem em atos puníveis, que são os estipulados pela lei penal, mas também podem produzir consequências civis, dirigidas ao ressarcimento do dano causado; e os atos ilícitos civis que transgridam preceitos civis. (VALDÉS DÍAZ, PÉREZ GALLARDO, et al., 2000, p. 302). Aliás, o Código Civil não faz menção ao ato lícito praticado em conformidade com a lei e que, de igual forma, pode produzir danos, ficando a vítima irressarcida, nesses casos, pela simples justificativa de encontrar-se a conduta danosa justificada por outra norma legal. Os juízes na resolução de um litígio devem considerar o abuso do direito, toda vez que, o exercício deste não pode ser ilimitado, senão que, está sujeito a restrições que respondem à convivência pacífica da sociedade. ${ }^{34}$

O Código Civil reconhece que o dano moral só repercute nos interesses estritamente morais da vítima. O legislador pretendeu distinguir a indenização do prejuízo, da reparação do dano, mas no caso de Cuba, ambas as expressões significam exatamente o mesmo. Esta distinção se justifica, pois a reparação se refere ao dano e a indenização ao prejuízo, considerando como dano o diretamente causado, e como prejuízo o indiretamente recebido. Assim o artigo 83 regula o dano emergente, no qual se incluem: a restituição do bem, a reparação do dano material, e a reparação do dano moral. O lucro cessante restou consignado, em relação ao expressado, no artigo 86 inciso d.

(...) El resarcimiento de la responsabilidad civil comprende: la restitución del bien; la reparación del daño material; la indemnización del perjuicio; y la reparación del daño moral. ${ }^{35}$

La indemnización de los perjuicios comprende: (...) otros ingresos o beneficios dejados de percibir por la víctima. ${ }^{36}$

\footnotetext{
${ }^{34}$ Ver artigos 131, 132, 166.2, e 173.2 do Código Civil referidos ao abuso do direito, todas limitantes do direito de propriedade. (CUBA, Ley No 59, de 16 de Julio de 1987. Código Civil)

35 Artigo 83 do Código Civil Cubano. (Trad.: O ressarcimento da responsabilidade civil compreende: a restituição do bem; a reparação do dano material; a indenização do prejuízo e a reparação do dano moral). (CUBA, Ley No 59, de 16 de Julio de 1987. Código Civil)

${ }^{36}$ Trad. artigo 86.d. A indenização dos prejuízos compreende: (...) outros ingressos e benefícios deixados de perceber pela vítima. Que seriam aqueles ingressos futuros que poderia haver recebido caso o dano não tivesse acontecido.
} 
2.

Neste Código é prevista a possibilidade de reparar o dano moral como conteúdo da responsabilidade civil, apenas através da retratação pública do ofensor ${ }^{37}$ não havendo maiores detalhes no concernente a sua execução, deixando à liberdade do tribunal determinar a forma mais efetiva para alcançar essa reabilitação. No entanto, no tribunal pesquisado não existe nenhuma decisão que tenha adotado esta forma de reparação, existindo apenas um caso por dano moral ajuizado nos últimos 10 anos, o qual será analisado mais adiante na presente dissertação. ${ }^{38}$ Percebe-se que é muito pequeno o âmbito concedido ao dano moral, não havendo reparação, e deixando desprotegidos os interesses puramente existenciais que se encontram inseridos na legislação, principalmente na Lei Fundamental, diante do preceito de dignidade humana.

Pode-se afirmar que em Cuba somente recebe amparo judicial o dano patrimonial, pois, a vítima de um delito é ressarcida economicamente quando esse evento lhe ocasionou uma afetação patrimonial. Por exemplo, todas as despesas incorridas pela vítima do delito ou seus familiares devem ser pagas pelo ofensor, nestes gastos se incluem: medicamentos, alimentos, transporte, salários deixados de perceber, etc., ou seja, não se ressarce pelo direito atingido, senão pela afetação econômica provocada no patrimônio do lesado. Concepção suscetível de dificuldade, ainda mais, diante do ponto de vista do sistema socialista. A sociedade e a completa proteção da personalidade dos seus indivíduos deve contemplar indefectivelmente o ressarcimento do dano moral, abarcando todas as possibilidades que sejam pertinentes. Desta forma, ao falar de compensação, não se está reparando o dano moral puro, mas a forma de completar o patrimônio da vítima, que se viu atingido ou diminuído pela presença do dano. Tudo isso está previsto no artigo 86 incisos, d) e e) da própria lei civil. Desta forma, pode-se afirmar que o dano moral que se deriva da comissão tanto de um ato ilícito civil ou penal, encontra-se desprotegido no sistema jurídico cubano.

As dificuldades previamente expostas não impossibilitam a reparação do dano moral em sede judicial, sempre e quando o juiz assuma um papel ativo na interpretação das normas que compõem o sistema jurídico. Como se sabe, a prática dos direitos inerentes ao indivíduo encontra-se condicionada pelo próprio

\footnotetext{
${ }^{37}$ Trad. Artigo 88: A reparação do dano moral compreende a satisfação do ofendido mediante a retratação pública do ofensor. (CUBA, Ley N ${ }^{\circ}$ 59, de 16 de Julio de 1987. Código Civil)

${ }^{38}$ Ver item 2.7
} 
2.

sistema e sociedade em que estão inseridos, e por isso, o Código Civil regula a boa-fé no artigo 6, princípio este que é presumido em qualquer relação que aconteça entre os membros da sociedade. De igual forma, o abuso do direito foi previsto como um límite ao exercício dos direitos concedidos ao cidadão cubano, os quais, devem ser praticados sem causar dano ao próximo, prescrevendo-se no artigo $4^{39}$ a ilicitude quando o objetivo seja causar um dano.

No caso concreto do menosprezo aos direitos inerentes à personalidade, alguns juristas cubanos percebem a probabilidade da sua reparação monetária no artigo $38 .^{40}$ No entanto, isso não é aplicado na prática judicial sob a escusa de que essa norma encontra-se no capítulo dedicado às pessoas naturais inserida no Livro Primeiro do Código Civil, negando a sua aplicação direta na matéria de responsabilidade civil. Ficando assim recusada a reparação econômica do dano moral, embora existam normas na própria lei, cuja interpretação análoga pode justificar a efetivação do ressarcimento econômico da lesão moral em Cuba.

De forma aparente, parece que o critério de responsabilidade objetiva é o que prevalece na norma civil, segundo o que estabelece os artigos 81 e 82 . Contudo, existem casos onde também se encontra estipulado o critério de responsabilidade subjetiva, ante a necessidade do dolo ou da culpa, o que se pode corroborar nos artigos 90-92. Já os artigos 93, 94 e 97 levam o cunho da responsabilidade objetiva, prevalecendo o dano, independentemente da culpa. Somente se pode entender o caráter objetivo de forma clara nos artigos dedicados às atividades que geram riscos ${ }^{41}$. Esta mistura traz como resultado que o tribunal adote qualquer critério de responsabilidade, exigindo ou não a prova da culpa.

O Código prevê a responsabilidade civil por fato de terceiro em seu artigo 90.1, estabelecendo a responsabilidade que incorrem os pais e os tutores, responsáveis pelos danos e prejuízos causados pelos menores de idade ou incapacitados, que tenham sob sua custódia. O que significa que, apesar das

\footnotetext{
39 Trad. Artigo 4. Os direitos que este Código reconhece hão de exercer-se de acordo com seu conteúdo social e finalidade, e não é lícito seu exercício quando o fim perseguido seja causar dano a outro. (CUBA, Ley № 59, de 16 de Julio de 1987. Código Civil)

${ }^{40}$ Expressa que a reparação dos direitos inerentes à personalidade constitucionalmente regulados, que afetem o patrimônio ou a honra de seu titular, confere a este e a seus herdeiros a possibilidade de exigir que cesse de imediato a violação ou a eliminação de seus efeitos, de ser possível; a retratação por parte do ofensor; e a reparação dos danos e prejuízos causados. (Código Civil, art.38)

${ }^{41}$ Ver artigos 104-107 dedicados às atividades que geram riscos. (CUBA, Ley No 59, de 16 de Julio de 1987. Código Civil)
} 
2.

incongruências da norma civil, seu objetivo é alcançar a responsabilização daquele que ocasione um dano, ou da pessoa que seja responsável, nos casos antes mencionados, em correspondência com os deveres jurídicos que impõe os artigos 85, 137, 151 e 155.5 do Código de Família. ${ }^{42}$ Porém, estas normas só são aplicáveis no caso dos danos materiais. $\mathrm{O}$ artigo 91 refere-se à responsabilidade das pessoas que trabalham em centros assistenciais, ou destinados a menores com transtornos, os que, de igual forma, têm responsabilidade civil pelos danos causados pelas pessoas que se encontram sob o seu cuidado, tudo o que se corresponde com o artigo 147 do Código de Família ${ }^{43}$.

Segundo o artigo 94, não fica eximida a responsabilidade pelos danos produzidos por um animal, presumindo-se a culpa pelo preceito in vigilando. (OJEDA RODRÍGUEZ e TERESA, 2000, p. 102), só eximindo-se de responsabilidade por caso fortuito, força maior, ou por culpa exclusiva da vítima. A norma civil também estipula a responsabilidade pela queda de objetos, desde um condomínio, respondendo civilmente o chefe do núcleo familiar, sem prejuízo do direito de reembolso que lhe corresponde exigir de quem ocasionou o dano de forma direta. Todas estas responsabilidades são de caráter objetiva e estão dirigidas à responsabilidade por danos patrimoniais.

A crítica fica mais propicia, diante da promulgação do Decreto Lei n ${ }^{\circ} 209$ de 2000, que introduz a função compensatória do dano moral através do dinheiro ${ }^{44}$. Aliás, esta norma apenas se encontra destinada à reparação por dano moral que sofrem as vítimas das agressões da política hostil dos Estados Unidos da América em face de Cuba, o que significa que a inovação que ela introduz não é aplicável em sede judicial, onde se manifestam danos morais provenientes de pessoas naturais ou jurídicas, nem sequer quando o ato danoso é praticado pelo Estado. Portanto, pode-se concluir que a figura jurídica em análise deva ser entendida como prevê o Código Civil vigente, limitando sua reparação à retratação pública por parte do ofensor.

Com a promulgação do referido Decreto Lei, pode ser iniciado um debate em relação à adoção do dano extrapatrimonial no ordenamento jurídico cubano, já

\footnotetext{
42 (CUBA, Ley No 1289, Código de Familia de 14 de febrero de 1975)

43 (CUBA, Ley No 1289, Código de Familia de 14 de febrero de 1975)

${ }^{44}$ Ver artigos 1 e 4 do Decreto-Lei 209, 20 de março de 2000.
} 
2.

que, embora possa ser entendido como inovador, certo é que, desde a sua promulgação, suas disposições não foram utilizadas para justificar aqueles casos em que o agente atuante não é o governo dos Estados Unidos, particular que identifica como injusto e desigual o tratamento desta figura de direito. Esse tratamento diferenciado encontra-se incoerente com o sistema socialista que rege no país, e a proteção da dignidade da pessoa humana. Em todo caso em que aconteça um dano moral injusto violador da dignidade humana, justifica-se a proteção da pessoa lesada, independentemente de quem seja o ofensor do dano, sendo obrigatória a interposição do adequado ressarcimento.

A respectiva norma, além de prever a reparação econômica do dano moral, justifica a interpretação da sua necessidade econômica a partir das normas constitucionais, fazendo alusão ao artigo 61, que revela a possibilidade da retroatividade da norma a ser aplicada naqueles casos em que se manifeste o interesse social ou a utilidade pública ${ }^{45}$. Entretanto, quando o ofensor não é o governo estadunidense, não se utilizam os preceitos civis e constitucionais de forma complementar para argumentar e conceder a adequada reparação.

Resulta mais fácil obter ressarcimento econômico naqueles casos que aconteçam dentro do território nacional, pois nestes eventos o órgão judicial vai contar com as vias idôneas para poder executar a decisão judicial, ao contrário do que acontece com as demandas interpostas contra o governo dos Estados Unidos, cujo cumprimento, sem dúvida alguma, encontra-se condicionado por muitos elementos externos e independentes da vontade do governo cubano. Assim, este processo acaba culminando com a irreparabilidade da vítima desses danos, encontrando-se na mesma posição dos restantes lesados, cujas demandas estão dirigidas a uma pessoa natural ou jurídica da própria sociedade.

Todas estas considerações incidem negativamente na aplicabilidade do dano moral, já que, devido à definição precária concedida pelo legislador cubano, e a impossibilidade de obter a sua valoração econômica pela inadequada interpretação do juiz, constitui uma figura legal cujo silencio na lei e na prática cubana trazem como resultado seu desconhecimento pela população, sendo compreendida como uma norma que pode ser inobservada sem gerar qualquer consequência jurídica.

\footnotetext{
45 Trad. Artigo 61. As leis penais têm efeito retroativo quando sejam favoráveis ao réu ou sancionado. As demais leis não têm efeito retroativo a menos que nas mesmas se disponha o contrário por razão de interesse social ou utilidade pública.
} 


\subsection{1. \\ Responsabilidade Civil proveniente do delito e sua regulação no Código Penal.}

Outro elemento objeto de exame é o concernente ao tratamento do dano moral em sede de responsabilidade penal. Mesmo que existam diferenças marcadas entre ambas responsabilidades, pode-se afirmar que a responsabilidade civil deriva do exercício de um delito, ficando estipulado no artigo 70. 1 que o responsável penalmente também tem responsabilidade civil pelos danos causados com o exercício do delito. O que resulta mais constrangedor é que o Código Penal no seu artigo 70.2 determina a prisão para aquele condenado por um delito penal que descumpre a reparação do dano moral provocado ${ }^{46}$.

Esta previsão destrói o entendimento da responsabilidade civil e a proteção da dignidade humana, ao ponto de decidir sobre um dos mais bens preciosos do ser humano: a liberdade. Porém, ao mesmo tempo, em sede de responsabilidade civil, o juiz não pode deferir o ressarcimento econômico do dano moral. Neste caso, parece que a liberdade do indivíduo é menos importante do que a sua obrigatoriedade de reparar de forma integral à vítima através de uma ação pecuniária. Tal fato é bastante controverso, confundindo-se, desta forma, a pena com o honra, ficando o dano moral irresarcido. Além disso, o direito penal é um direito de última ratio devendo-se acudir a ele quando hajam sido esgotadas todas as vias possíveis em matéria civil.

Quando a responsabilidade civil se deriva de um delito, esta se exercita conjuntamente com a penal, a não ser que exista um lesionado, pelo qual ainda fica pendente o atestado da sua sanidade, segundo determina o artigo 275 de Lei Processual Penal. (CUBA, Ley No 5, Ley de Procedimiento Penal de 13 de agosto de 1977). Todos os fatos culposos ou dolosos exigem uma responsabilização ainda que não estejam estipulados na lei. Contudo, somente podem ser reprimidos por uma pena, caso estejam regulados na lei penal, respondendo, desta forma, ao

\footnotetext{
${ }^{46}$ Trad. Artigo 70.2 Em caso, se o sancionado se nega a realizar os atos que lhe concernem para a execução da reparação do dano moral, o tribunal lhe aplicará prisão subsidiaria por um termo que não pode ser inferior a três meses nem exceder a seis. Em qualquer momento em que o sancionado cumpra sua obrigação se deixará sem efeito o que lhe reste por cumprir da sanção subsidiária, arquivando-se as atuações. (CUBA, Ley Nº 62, Código Penal de 29 de diciembre de 1987)
} 
2.

princípio da legalidade nullum crimen, nulla poena, sine praevia lege penale. (OJEDA RODRÍGUEZ e TERESA, 2000, p. 103)

O estipulado no artigo 8.2 do Código Penal é significativo ao estabelecer que naqueles delitos de escassa periculosidade social, a pessoa afetada pelos danos e prejuízos pode reclamar, com base na responsabilidade civil, contra o agente que os haja produzido ante a via civil. De igual forma, a extinção da responsabilidade penal não influi na extinção da civil. $O$ artigo 276 faculta ao titular da ação civil a possibilidade de exercitá-la sempre que a sentença na via penal não tenha declarado a inexistência de um delito, pelo qual, ambas as responsabilidades são independentes.

Uma peculiaridade da responsabilidade civil derivada de delito consiste na forma de fazer efetiva sua reparação. Em Cuba, consolida-se através da Caixa de Ressarcimento, entidade encarregada de fazer efetiva a responsabilidade civil proveniente de delito, consistente na reparação de danos materiais e a indenização dos prejuízos. Seus precedentes se encontram nas caixas de multas dos Conselhos de Patronato do Projeto Ferri, a Caixa de Multas criada na Itália pela Lei do dia 9 de maio de 1932, a Caixa Nacional de Ressarcimento do Projeto Ortiz, e a Caixa Nacional de Ressarcimento do Projeto Tejera. (SMITH RAMOS, 1983, p. 311) A caixa tem como fim a intervenção do Estado, esta demanda o pagamento dos obrigados e abona à vítima do dano as quantidades que lhe são devidas.

Na via civil também se autoriza o uso da caixa, segundo aprova a Instrução 104 de 16 de fevereiro de 1982, emitida pelo Conselho de Governo do Tribunal Supremo Popular, especificamente naqueles casos em que esteja pendente o atestado de sanidade da vítima que teve lesões por consequência do dano ocorrido. A caixa somente não assume sua função naqueles casos em que o autor dos danos tenha abonado a soma devida à vítima antes da celebração do juízo oral, o que se encontra expresso no Ditame 212 do Conselho de Governo do Tribunal Supremo Popular. (CUBA, Dictamen No 212, de 8 de enero de 1985)

Desde o derrogado CDS no seu artigo 122 expressava-se a função da caixa de ressarcimento, encarregada de cumprir as execuções no que concerne à responsabilidade civil do sancionado, uma vez proferida a sentença penal, que definirá as indenizações ou reparações acordadas pelo tribunal, ou as pensões que 
2.

disponha a sentença. A caixa fica sub-rogada pelo pagamento dos direitos da vítima, podendo ser parte na causa e perseguir o sancionado para o reembolso da responsabilidade civil que abonou por ele. Neste sentido, o réu está obrigado a satisfazer a caixa nas responsabilidades que se lhe sejam impostas, e em caso de insolvência lhe exige ao acusado a entrega da quarta parte de suas entradas mensais (SMITH RAMOS, 1983, p. 312-313), ou pode dispor-se a apreensão dos bens que possua, com exceção daqueles excluídos no Código Civil. ${ }^{47}$

Do anterior conclui-se que o prejudicado deve sempre dirigir sua reclamação à caixa de ressarcimento que, em virtude da sub-rogação legal, é responsável por todas estas indenizações. No entanto, quando cessa a sua responsabilidade criminal, derivada do delito, por qualquer causa, então desaparece a intervenção da caixa, ficando o lesante compelido pela via civil, respondendo diretamente ante a vítima. (SMITH RAMOS, 1983, p. 314). De igual forma, a caixa tem a faculdade de requerer a reclusão do sancionado insolvente em um estabelecimento, para que com o produto de seu trabalho satisfaça as responsabilidades devidas, devendo em outro caso fixar o tribunal a prisão subsidiária, que não excederá o prazo de 6 meses, a que sofrerá o réu pela falta de pagamento da responsabilidade civil. Esta entidade encontra-se sob a custódia do Ministério de Justiça, na sua condição de Fazenda Pública. A solicitação de pagamento deve ser feita pelo prejudicado ou seus herdeiros, conforme o art. 71 do Código Penal ${ }^{48}$. (SMITH RAMOS, 1983, p. 322)

A caixa de ressarcimento é um mecanismo efetivo no sistema jurídico, mas só é aplicado na via penal quando se evidenciam danos patrimoniais derivados da comissão de um delito, ou na via civil quando está pendente o atestado de sanidade da vítima. Fora desses casos, seu procedimento não é utilizado na via civil, ficando o dano moral irresarcido. No sistema cubano não existe nenhuma proibição que permita adotar de forma análoga as funções deste organismo para serem aplicadas no processo civil, não obstante, os intérpretes do direito esquecem a necessidade da proteção da pessoa ante todos os atos que infrinjam sua

\footnotetext{
${ }^{47}$ Ver artigos 89.1; 138. 1; 144.1; 149.1; 155 do Código Civil cubano.

${ }^{48}$ Trad. Artigo 71 do Código Penal modificado pelo artigo 15 Decreto-Lei No. 175 de 17 de junho de 1997 (G.O. Ext. No. 6 de 26 de junio de 1997, pág. 40): A Caixa de Ressarcimentos é a entidade encarregada de fazer efetiva as responsabilidades civis consistentes na reparação dos danos materiais e a indenização dos prejuízos. A esses efeitos, exigirá o pago aos obrigados e abonará às pessoas naturais que resultem vitimas do delito as quantidades que lhes são devidas.
} 
2.

dignidade humana, já se derivem de um ato ilícito civil ou penal, assim como, da violação do princípio alterum non laedere. Em Cuba somente recebe adequado ressarcimento, tanto na via civil quanto na via penal, o dano material.

Por outra parte, a Instrução 109 do dia 27 de abril de 1983 do Tribunal Superior de Justiça regula a improcedência de indenizar os herdeiros de um pai de família que falece, salvo se dependiam economicamente do finado (Juris Cuba, 2017). Consideração que resulta injusta, já que existem inúmeros casos que devem ser analisados em concreto, não resultando necessária uma lei que limite a reparação, senão que devesse realizar a valoração de cada caso em particular, tendo em consideração não só a afetação econômica ocasionada com o delito senão também o dano moral suportado de forma injusta. $\mathrm{O}$ direito civil, diferente de outros ramos, é um direito muito amplo, mutável e condicionado pelas situações sociais desiguais, devendo o legislador adaptar-se a essas novas mudanças sociais, e a partir daí direcionar as normas legais a dar solução nesses casos. Justamente, ante a impossibilidade de que o legislador concentre na lei os inúmeros casos que acontecem na vida social, cabe aos intérpretes e aplicadores do direito buscar alternativas legais para responder às demandas sociais, diante do imperativo de vulnerar a proteção à dignidade da pessoa humana.

Não é menos certo que o Código Penal tem uma importância marcada no ordenamento cubano, mas isso se deriva da conotação feita pelo legislador ao colocar na via penal a proteção de muitos direitos inerentes ao ser humano, cuja regulação não aparece consignada na Constituição, tampouco no Código Civil, por exemplo, os direitos à vida e à honra ${ }^{49}$. Resulta mais inovador e garante o Código Penal do que a própria Constituição, ao reconhecer direitos humanos adotados em Documentos Internacionais, que não se regulam pela Constituição.

Além disso, em Cuba, a regulação penal pressupõe a prática de um dano punitivo, pois com a percepção do dano moral, não se está procurando a reparação integral da vítima desse prejuízo, senão o castigo do causante do detrimento, configurando-se um exemplo para a sociedade, com o fim de que esse ato não seja cometido novamente. Neste caso, responde-se ao interesse geral, ao contrário de quando o causante é obrigado a responder pela via civil, na qual se tenta responder

\footnotetext{
${ }^{49}$ Encontram-se regulados nos artigos 318-321, Título VIII capítulos II ao VIII (CUBA, Ley N ${ }^{\circ}$ 62, Código Penal de 29 de diciembre de 1987)
} 
2.

e dar solução ou atenuar as consequências prejudiciais ocasionadas à vítima. (ALVAREZ VIGARAY, 1966, p. 99) A função da responsabilidade civil é indenizatória, e só cumpre uma função punitiva e preventiva de forma indireta na medida de que a condenação seja percebida como castigo ou exemplo para o resto da sociedade. Portanto, com exceção desses casos, só deve ser valorada a função indenizatória. (OJEDA RODRÍGUEZ e TERESA, 2000, p. 88)

Desta forma, permanece qualificado o dano moral no ordenamento jurídico cubano, cujo tratamento prático resulta desconexo com a realidade social imperante, não só dentro do próprio país, senão também no mundo inteiro. Precisamente no caráter socialista, deve ser argumentada a desnecessidade de entender a reparação do dano moral apenas naqueles casos onde se evidenciam aspectos patrimoniais, ou quando esse dano se deriva da comissão de um delito. Precisa-se de uma mudança de pensamento, não só modificando as penas e sanções impostas, mas também exigindo o estabelecimento da prisão quando não existem outras vias pelas quais possa lograr-se o ressarcimento do dano moral. A privação da liberdade seria necessária em última instância quando o fato cometido e as circunstâncias pessoais de seu autor constituam um perigo para a sociedade, ou quando a proteção desta assim o exija. (SMITH RAMOS, 1983, p. 406)

O elemento que fica claro neste debate é o dano, onde sempre que se configure, de forma injusta, a responsabilidade jurídica civil deve se fazer presente e exigir a reparação procedente. Por esta razão, parte vanguardista da doutrina cubana entende que a responsabilidade civil tem uma função compensatória, ou de ressarcimento, diferentemente da penal, priorizando a situação da vítima que sofre o dano, e se fazendo imprescindível a objetivação da responsabilidade, tanto em sede judicial, como nas possíveis modificações legislativas. Portanto, propõe-se uma complementação das teorias subjetivas e objetivas para fundamentar a responsabilidade e conceder a correspondente reparação. (VALDÉS DÍAZ, PÉREZ GALLARDO, et al., 2000, p. 332)

\section{7. \\ Valoração das resoluções emitidas pelo Tribunal Provincial Popular de Camagüey, Cuba, nos últimos 10 anos.}

Os elementos antes debatidos corroboram a dificuldade do entendimento do dano extrapatrimonial do sistema cubano. Sua definição, qualificação, regulação 
2.

no sistema legal, e, finalmente, o seu exercício em sede judicial, respondem a uma inadequada interpretação da figura em estudo, trazendo como resultado visível a desproteção da pessoa humana pelo ordenamento jurídico de forma geral. Primeiramente, deve-se explicar que pelas caraterísticas próprias do sistema cubano, as que foram previamente explicadas ${ }^{50}$, os casos civis não são disponibilizados de forma pública em sites ou em documentos eletrônicos. O trabalho judicial guarda-se em arquivos de forma física (CUBA, Ley $\mathrm{N}^{\circ}$ 7, Ley de Procedimiento Civil, Administrativo, Laboral y Económico de 19 de agosto de 1977, art. 157). A atividade judicial fica registrada no mesmo tribunal, em livros de controle que são confeccionados para esses fins. (Cuba, Reglamento de la Ley 82, Ley de los Tribunales Populares de 11 de julio de 1997, arts. 76-87, 90-92)

Isto significa que, a diferença do Brasil, onde a pesquisa jurisprudencial foi realizada de forma digital, em Cuba efeituou-se o estudo dos arquivos físicos do tribunal. A dificuldade da pesquisa eletrônica ocorre em razão do sistema cubano não contar com esse avanço tecnológico. Os expedientes judiciais se criam de forma manual pelos trabalhadores do tribunal, encontrando-se a maior parte das informações em papel, o que dificulta uma possível divulgação dos casos que são resolvidos. Nos últimos tempos, está sendo realizando um trabalho conjunto entre o Tribunal Supremo Popular e a Universidade das Ciências Informáticas, com o fim de informatizar a atividade judicial (ISABEL e RIVERA RIQUENES, 2017). Isso pressupõe que, nos próximos anos, será possível o acesso a estes casos. No entanto, até os dias atuais esta colaboração ainda não se efetivou.

Embora os tribunais cubanos sejam populares ${ }^{51}$ as sentenças dos juízes em cada matéria não têm essa caraterística, pois as notificações apenas são encaminhadas às partes do processo $^{52}$, uma vez que apenas os casos mais transcendentais são divulgados por meio dos boletins do Tribunal Supremo Popular. Portanto, os restantes assuntos de grande envergadura que acontecem em outros tribunais do país, acabam caindo em desconhecimento social. Não obstante, a pesquisa do presente trabalho foi realizada com sucesso, dada a cooperação de alguns membros do tribunal, e também dos advogados que representaram às

\footnotetext{
${ }^{50}$ Ver infra. Cap. 2.2

${ }^{51}$ Ver no artigo 115 da LPCALE (CUBA, Ley N ${ }^{\circ}$ 7, Ley de Procedimiento Civil, Administrativo, Laboral y Económico de 19 de agosto de 1977).

${ }^{52}$ Encontra-se previsto no artigo 158 da LPCALE (CUBA, Ley N ${ }^{\circ}$ 7, Ley de Procedimiento Civil, Administrativo, Laboral y Económico de 19 de agosto de 1977)
} 
2.

partes no único assunto por dano moral julgado, nos últimos dez anos, perante o Tribunal Provincial Popular de Camagüey.

Todos os tribunais do país já apreciaram múltiplos casos envolvendo danos, que tiveram origem na comissão de delitos, mas com implicações patrimoniais. Para além desses casos, somente encontrou-se uma decisão que tratou de uma controvérsia envolvendo um dano moral puro. $\mathrm{O}$ assunto versou no expediente número 11 do ano 2011, em Processo Ordinário sobre Ressarcimento da Responsabilidade Civil derivada da violação dos Direitos Inerentes à Personalidade. No assunto, sustentava-se a vulneração dos direitos de uma pessoa que não havia consentido que seu nome e dados constassem em um livro chamado "Cerca del cerco", pedido que foi feito antes que o livro fosse divulgado. O livro relatava alguns trechos da luta contra os bandidos, logo após do triunfo da Revolução, e as medidas que foram adotadas contra os contrarrevolucionários daquela época, entre os quais, segundo o escritor, figurava o demandante.

Não obstante, o livro foi divulgado, cuja edição contou com 488 exemplares, constando nos livros os dados pessoais do demandante. Na obra, o ator era chamado de contrarrevolucionário, entre outras associações que não eram verdadeiras, afetando sua moral e honra, além de o livro utilizar de maneira não autorizada os seus dados. Por tal motivo, o ofendido ajuizou a demanda, alegando ter sofrido um dano à sua moral e à sua honra, defendendo outra versão da história, diferente daquela manifestada pelo escritor.

O demandante dirigiu sua demanda contra o autor e coautor da obra, a editora que a publicou e contra o Centro Provincial do livro da província de Camagüey. Ele exigiu que cessasse imediatamente a violação aos seus direitos, requerendo pela eliminação de seus efeitos. Assim, pleiteou pela (i) reformulação do livro, para que o mesmo não fizesse menção à sua pessoa, assim como (ii) a retratação pública do ofensor, solicitando que os restantes demandados recolhessem 10 exemplares dos livros que se encontravam na feira do livro da Havana, junto com outros 370 que estavam localizados no Centro Provincial do Livro de Camagüey, e que todos esses exemplares fossem incinerados, uma vez que os restantes foram vendidos, e o autor desconhecia seu paradeiro. O tribunal julgou improcedente a demanda, por meio da sentença número 47 do dia 24 de agosto de 2011, pela juíza Jackeline Hernández Padrón, quem decidiu: 
(...) la demanda establecida por Juan García Molina no puede prosperar habida cuenta de que el daño moral que produce la violación de los derechos inherentes a la personalidad deben derivarse de un acto ilícito y en el caso en análisis no ha quedado acreditado con ninguno de los medios de prueba que constan en autos, pues al remitirse a las páginas del libro solo se detallan algunas de las actividades contrarrevolucionarias en que participó el demandante durante la etapa de lucha contra bandidos (...) y específicamente en la página 114 del mencionado texto se dice que el recurrente era agente de la contrainteligencia cubana y en tal sentido el daño moral que en definitiva pudo haberle sobrevenido en las primeras manifestaciones de los autores del libro, quedó esclarecido con posterioridad en la citada página (...) debe entenderse que estamos en presencia de una persona que ha vivido con apego a los principios revolucionarios, sin que pueda realizarse interpretación distinta en tal sentido. ${ }^{53}$

A decisão assumida pela juíza atuante pressupõe a necessidade de uma mudança na função judicial ante a presença de um dano moral, sendo necessária, a interpretação mais abrangente do poder judicial, na sua qualidade de órgão máximo interpretativo das leis. No caso em análise, o tribunal não emitiu uma sentença justa, não fez uso das normas constitucionais e civis, cuja valoração conjunta, possibilitava a reparação do dano moral. Ainda que no livro ficasse esclarecida a condição do demandante, questão que também foi refutada pela vítima, evidencia-se um ato ilícito pelo simples fato de ter sido divulgada a obra sem seu consentimento, utilizando dados sensíveis referentes ao passado do lesado, quem simplesmente não autorizou sua revelação, quiçá porque queria esquecer esse acontecimento.

No caso que nos ocupa, o fato de escrever-se um livro acerca de algumas atividades pertencentes à vida de outra pessoa sem que exista sua autorização prévia, com a divulgação de fatos falsos ou ainda verdadeiros, irremediavelmente conduziria a uma completa reparação do indivíduo lesado, que poderia ter sido satisfeita se as pretensões do demandante tivessem sido atendidas, mas também poderia ter sido efetivada por meio da reparação pecuniária. Neste caso, restou configurado o dano injusto, transgressor à honra da vítima, através do uso não autorizado de seus dados, sendo questionável a veracidade da informação que

${ }^{53}$ Trad. (...) a demanda estabelecida por Juan García Molina não pode prosperar, pois o dano moral que produz a violação dos direitos inerentes à personalidade deve derivar-se de um ato ilícito e no caso em análise não tem ficado acreditado com nenhum dos meios de prova que constam nos autos, pois, no livro só se detalham algumas das atividades contrarrevolucionárias em que participou o demandante durante a época de luta contra bandidos (...) e especificamente na página 114 do mencionado texto se diz que o demandante era agente da contra inteligência cubana e em tal sentido o dano moral que em definitiva lhe poderiam ter causado nas primeiras manifestações dos autores do livro, ficou esclarecido com posterioridade na citada página (...) estamos em presença de uma pessoa que tem vivido com apego aos princípios revolucionários, sem que possa realizar-se interpretação distinta em tal sentido. 
constava no livro, como assim ficou demonstrado no processo. Logo, pode-se dizer que o órgão judicial errou na sua decisão, pois de forma incorreta entendeu pela não configuração do dano moral diante da ausência do ato ilícito, quando de forma contrária ficou comprovado o dano extrapatrimonial lesante da dignidade da vítima, vulnerador do neminen non laedere e da honra do titular, atributos que devem ser ponderados com o direito do lesante.

No assunto, não existia uma questão de interesse público que exigisse a publicação do livro, pois se tratava de informações que não precisavam estar no domínio público. Inclusive, o autor poderia se valer de outros meios para contar a história, como por exemplo, poderia ter omitido os dados do lesado, mas, ao não respeitar a vontade daquele, acabou por violar o princípio da boa-fé, tendo exercido seu direito de forma abusiva. De igual forma, pode-se afirmar pela existência de um dano material, pois os livros foram vendidos, e os autores e editores receberam benefícios econômicos, que deveriam corresponder à indenização de danos e prejuízos atribuídos à vítima.

Neste caso, também pode ser aplicado o direito ao esquecimento. Em Cuba, ainda não está reconhecido, resultando em um direito inovador que pode ser solicitado de forma acertada pelo lesado, já que estava em seu direito esquecer esses momentos desagradáveis dos que foi partícipe. Os tribunais brasileiros adotaram esse direito no recurso extraordinário: 101066 no Supremo Tribunal Federal (STF) da Aída Curi e da Chacina da Candelária no recurso 789.246. ${ }^{54}$

A adoção do direito ao esquecimento, pelo órgão judicial brasileiro, entrou na pauta jurisdicional com mais contundência desde a edição do Enunciado 531, da VI Jornada de Direito Civil do Conselho da Justiça Federal (CJF). Embora não existe uma decisão definitiva em relação a seu confronto com o direito à informação; a orientação doutrinária está baseada na interpretação do Código Civil que regula o direito de ser esquecido como direito da personalidade, já que, ninguém é obrigado a conviver para sempre com erros pretéritos, entendimento que se faz extensivo através do princípio constitucional da dignidade da pessoa humana, proibindo a veiculação de informações que atinjam aquele princípio. $\mathrm{O}$ ministro Luís Felipe Salomão, em relação a este tema, expressou:

${ }^{54}$ http://www.stf.jus.br/portal/jurisprudencia/listarJurisprudencia.asp?s1=\%28DIREITO+AO+ESQ UECIMENTO\%29\&base=baseRepercussao\&url=http://tinyurl.com/hbsvl4r. 
2.

"Não se pode, pois, nestes casos, permitir a eternização da informação. Especificamente no que concerne ao confronto entre o direito de informação e o direito ao esquecimento dos condenados e dos absolvidos em processo criminal, a doutrina não vacila em dar prevalência, em regra, ao último" 55 .

No referente ao assunto apresentado ante o tribunal cubano, não existem dúvidas de que o direito ao esquecimento pôde ter sido considerado caso estivesse reconhecido em Cuba, não obstante ainda assim, a decisão da julgadora não concedeu a proteção que merecia o prejudicado da lide sometida a sua consideração, ficando infringida de forma injusta a dignidade do lesado, quem tolerou de forma injustificada as consequências do evento danoso.

${ }^{55}$ https://amagis.jusbrasil.com.br/noticias/100548144/stj-aplica-direito-ao-esquecimento-pelaprimeira-vez. 


\section{3. \\ Tratamento e aplicação do Dano Moral no Ordenamento Jurídico Brasileiro.}

\section{1. Evolução da Responsabilidade Civil e seus elementos distintivos.}

De igual forma no Brasil, o papel da responsabilidade civil modificou-se com a consecutiva mudança da sociedade, ao demandar energicamente o reconhecimento amplo da pessoa humana. Nos seus primórdios, o instituto se concebia como a via para castigar aqueles atos que agiam em contradição com o regulado nas leis vigentes; concebido também, como exemplo para o resto dos cidadãos (DÍEZ PICAZO, 1999, p. 85), ao reprimir condutas não toleradas e proibidas pelo sistema legal estabelecido. Surgiria assim, com a ideia de punição inserida no seu tratamento (MULHOLLAND, 2010, p. 14), sem tomar em consideração a necessidade da reparação da vítima da lesão.

Os elementos que inicialmente a identificavam eram: a culpa, o dano e o nexo causal; porém, com a proliferação do capitalismo industrial e ante a dificuldade de provar a culpa do agente, pela imensa magnitude de acontecimentos tanto intencionais, imprudentes como acidentais que aconteciam, foi iminente rejeitar a teoria subjetiva ${ }^{56}$, e ceder passo à teoria objetiva ou do risco, não sendo necessário comprovar, nesses termos, a conduta do agente causador do dano. (SCHREIBER, 2007, p. 17-19).

Desta forma, foi posicionada a vítima como o ente primordial a ser valorizado na doutrina da responsabilidade civil, afastando-se hoje em dia a verificação da culpa de quem ocasiona o prejuízo, e centrando-se a análise propriamente no resultado do dano sofrido (ilicitude objetiva do dano). A partir de então, constituem elementos da responsabilidade civil: a culpa, o risco, o dano e o

\footnotetext{
${ }^{56}$ Isso não significava a substituição da responsabilidade objetiva pela subjetiva, senão que se adotava uma visão destinada à vítima, em razão dos danos que até esse momento ficavam sem reparação, justamente pelo papel que desempenhava a culpa como elemento constitutivo da responsabilidade civil. Desta forma, foram tidos em consideração os riscos criados, já fosse, pelo próprio avanço da sociedade e da tecnologia, ampliando-se assim, a área de atuação da responsabilidade civil. (BITTAR, 1991, p. 162)
} 
3.

nexo causal. Precisamente este tem sido o tratamento seguido no Brasil, através do art.927 do Código Civil, especificamente no seu parágrafo único dedicado à responsabilidade civil por risco $^{57}$, além disso, foram transformadas em responsabilidade objetiva muitas hipóteses, que antigamente, presumia-se a culpa, como se evidencia no caso do artigo $931^{58}$.

Com a teoria do risco ficou substituída a imputabilidade pela causalidade, pois, não se fazia pertinente avaliar a conduta do agente por meio do juízo de imputação; senão valorar o resultado proferido pelo lesante. No ordenamento concretizou-se a responsabilidade objetiva com a Constituição Federal de $1988^{59}$, a que, autorregulou este tipo de responsabilidade, ao igual que outras leis ${ }^{60}$ que; decidiram rejeitar a noção individualista para adquirir uma nova noção regida pela solidariedade social ${ }^{61}$. Estas leis instituíram de forma clara a responsabilidade objetiva independente da subjetiva. (SCHREIBER, 2007, p. 20) .

${ }^{57}$ Haverá obrigação de reparar o dano, independentemente de culpa, nos casos especificados em lei, ou quando a atividade normalmente desenvolvida pelo autor do dano implicar, por sua natureza, risco para os direitos de outrem. (BRASIL. Lei $\mathrm{N}^{\circ}$ 10.406, de 10 de janeiro de 2002, art. 927).

${ }^{58}$ Ressalvados outros casos previstos em lei especial, os empresários individuais e as empresas respondem independentemente de culpa pelos danos causados pelos produtos postos em circulação. (BRASIL. Lei $\mathrm{N}^{\circ}$ 10.406, de 10 de janeiro de 2002, art. 931).

${ }^{59}$ No artigo $37 \S 6^{\circ}$ se expressa que: A administração pública direta e indireta de qualquer dos Poderes da União, dos Estados, do Distrito Federal e dos Municípios obedecerá aos princípios de legalidade, impessoalidade, moralidade, publicidade e eficiência e, também, ao seguinte: (...) As pessoas jurídicas de direito público e as de direito privado prestadoras de serviços públicos responderão pelos danos que seus agentes, nessa qualidade, causarem a terceiros, assegurado o direito de regresso contra o responsável nos casos de dolo ou culpa. $\mathrm{O}$ art. $7^{\circ}$ estabelece: São direitos dos trabalhadores urbanos e rurais, além de outros que visem à melhoria de sua condição social: (...) XXVIII seguro contra acidentes de trabalho, a cargo do empregador, sem excluir a indenização a que este está obrigado, quando incorrer em dolo ou culpa. O art. 21.d expõe: Compete à União (...) a responsabilidade civil por danos nucleares independe da existência de culpa (BRASIL. Constituição da República, de 5 de outubro de 1988).

${ }^{60} \mathrm{O}$ Decreto 2.681 de 7 de dezembro de 1912 foi o primeiro caso de responsabilidade civil fundada na teoria do risco. Este dispositivo responsabiliza as Estradas de Ferro por todos os danos que na exploração de suas linhas causarem aos proprietários marginais, independentemente de qualquer culpa. De igual forma o Código Brasileiro de Aeronáutica, Lei 7.565 de 1986 nos artigos 268 e 269. O Decreto 3.724 de 15 de janeiro de 1919 começou a regular o Acidente do trabalho, seguido pelo Decreto 24.637 de 10 de julho de 1934, depois pelo Decreto-Lei 7.036 de 10 de novembro de 1944 e com a Lei 5.316 de 14 de setembro de 1967 regulamentada pelo Decreto 61.784 de 28 de novembro de 1967. No Decreto-Lei 227 Código de Mineração art.47 VIII de 28 de fevereiro de 1967. A Lei 6.938 de 1981 no seu art.14.1 danos causados ao meio ambiente e a Const., art. 225. O Código de Proteção e Defesa do Consumidor Lei 8.078 de 1991 consagrou a responsabilidade objetiva arts. 12, 14, 18, 19 e 20. A Lei 10.406, Código Civil consagrou o exercício de atividade de risco ou perigosa no parágrafo único do art. 927; danos causados por produtos art. 931; responsabilidade pelo fato de outro art. 932 e 933; responsabilidade pelo fato de coisa ou de animal art. 936, 937 e 939; responsabilidade dos incapazes art. 928, etc. (CAVALIERI FILHO, 2004, p. 150-158) (BITTAR, 1994, p. 170-175)

${ }^{61} \mathrm{O}$ princípio da solidariedade social é explicado pela professora Maria Celina, fazendo uma valoração da solidariedade fática que decorre da imprescindível coexistência humana, e a solidariedade como valor que é produto da consciência racional dos interesses em comum, sendo a 
3.

A cláusula prevista no artigo 927 do Código Civil tem suscitado muita polêmica, já que, da simples leitura parece indicar que oferece tutela a todo risco que possa padecer uma pessoa por causa da ação de outra. Embora alguns autores entendam que essa cláusula está dirigida àqueles riscos graves (SCHREIBER, 2007, p. 23); isto não é especificado na norma antes alegada, a qual pode ser objeto de inúmeras interpretações que possibilitam a proteção jurídica da vítima de todo risco derivado da atividade habitualmente desenvolvida. Por isso, há quem percebe esta cláusula como supra generalizadora, que concede amparo àqueles meros acontecimentos que devem ser suportados pelo titular do direito atingido (BODIN DE MORAES, 2003, p. 303), justamente por estar inserido em uma sociedade onde deve mediar o entendimento e a tolerância.

A partir deste acontecimento, parece que, o elemento culpa ficou esquecido no sistema legal brasileiro deixando de ocupar um papel preponderante na valoração do dano moral sendo completamente suprida pela noção de risco, e assim o explica Anderson Schreiber ${ }^{62}$, já que, a diferença do que acontecia no passado, hoje a responsabilidade objetiva se encontra em uma posição superior à subjetiva inicialmente abraçada pelo sistema; atingindo-se um processo social e jurídico de desculpabilização da responsabilidade civil. (MULHOLLAND, 2010, p. 21-22). Questão suscetível de crítica, pois, a culpa ainda é um elemento válido para determinar a obrigação de ressarcir através da análise da relação existente entre a conduta do ofensor e o dano derivado desse atuar.

Pouco a pouco tem se expandido o entendimento de que sempre que aconteça um risco, então a culpa do agente fica demonstrada ainda que ele tivesse tentado evitar esse prejuízo. Em relação à concepção objetiva da culpa atenuou-se a necessidade da sua constatação. Desde o ponto de vista moral, pode-se dizer que existe uma espécie de injustiça no tratamento deste elemento, pois, ao ficar o

obrigação moral dos membros da sociedade "não fazer aos outros o que não se deseja que lhe seja feito", conceito dialético que se traduz no reconhecimento pelo outro. Assim justifica-se o princípio de igualdade fundado em valores sociais, o qual está influído pela solidariedade social que à vez serve de base à igualdade substancial e à justiça social. O princípio constitucional da solidariedade identifica-se com o conjunto de instrumentos voltados para garantir uma existência digna, comum a todos, em uma sociedade que se desenvolva como livre e justa, sem excluídos ou marginalizados. (BODIN DE MORAES, 2003, p. 111-114)

${ }^{62}$ Está acontecendo a erosão dos filtros da responsabilidade civil, já seja, pela relativa perda da importância da prova da culpa e da prova do nexo causal na dinâmica contemporânea das ações de indenização. A culpa é presumida, sobretudo nos danos provenientes dos riscos, o que trouxe como consequência o aumento das ações reclamando indenização por danos morais (SCHREIBER, 2005, p. 47) 
3.

homem definido por um padrão de conduta inserido na sociedade, embora ele tentasse evitar o dano, considera-se culpável por não ter agido em correspondência com o homem bom que a sociedade de forma imaginária criou. Tudo o que confirma que, nestes casos a culpa é presumível, seja qual for a ação que intente fazer o agente para evitar um dano maior. (SCHREIBER, 2007, p. 35)

Tem se apresentado duas correntes da culpa: a concepção psicológica e a concepção normativa, cujas diferenças radicam na especificação dos requisitos que se devem configurar para que o comportamento em questão possa gerar a correspondente responsabilidade. A concepção psicológica entende a culpa como violação de um dever preexistente ${ }^{63}$ e a normativa a concebe através do erro de conduta, concepção que majoritariamente rege no Brasil.

Se o dever surge em virtude da lesão de um direito subjetivo, sem que entre o ofensor e a vítima preexista qualquer relação jurídica que o possibilite, temos a responsabilidade extracontratual, também chamada de ilícito aquiliano ou absoluto. Tanto na responsabilidade civil contratual como na extracontratual há a violação de um dever jurídico preexistente. ${ }^{64}$

Esta segunda noção praticamente substituiu à primeira, ante a necessidade de não só enquadrar o elemento culpa na sua relação intrínseca com uma norma, senão, no erro da conduta do agente reprovado pela coletividade, vulnerador do padrão que foi estabelecido, em virtude dos princípios gerais alterum non laedere ou neminem laedere ${ }^{65}$ e a boa-fé presumível em toda relação humana. Concepção que ainda em Cuba não se encontra inserida como regra legítima a ser seguida pelo órgão jurisdicional, já que, adota-se a responsabilidade civil baseada na concepção psicológica da culpa, precisando de uma norma infringida para poder entender a respectiva responsabilidade.

\footnotetext{
${ }^{63}$ M. PLANIOL, Traité élementaire de droit civil, v.II, p. 863 apud C.M. DA SILVA PEREIRA, Responsabilidade Civil, p.67, a manifestação voluntária do agente em relação à que surge o referido dano, mas critica-se esta concepção porque para que se concreta a responsabilidade ter-seia que violar uma norma ou um contrato pré-estabelecido (V. Jayme, SANTOS BRIZ, Responsabilidad civil, derecho substantivo y procesal. Madrid: Montecorvo, 1993, 2 v, p.53) In: (BODIN DE MORAES, 2003, p. 210-211).

${ }^{64}$ (CAVALIERI FILHO, 2004, p. 37). Gustavo Tepedino também expressou a ideia de dano injusto a partir do descumprimento de um dever jurídico; (TEPEDINO, 2004, p. 192-193) De igual forma, são defensores desta concepção C.M. DA SILVA PEREIRA, Instituições de Direito Civil, 18 ed, Rio de Janeiro, Forense, 1995, v I, p. 419. V. JSANTOS BRIZ, Responsabilidad civil, p.53; G. TEPEDINO, Problemas de Direito civil-constitucional, Rio de Janeiro: Renovar, 2000, p.55-75. In: (BODIN DE MORAES, 2003, p. 211-212)

${ }^{65}$ Clóvis Biviláqua, Código Civil dos Estados Unidos do Brasil, Rio de Janeiro, Ed. Rio, 1977, edição histórica, $7^{\mathrm{a}}$ tiragem, p.425. In: (COUTO DE CASTRO, 2005, p. 7). De igual forma, é partidário desta concepção: (CAVALIERI FILHO, 2004, p. 23)
} 
3.

Cabe-se dizer que a responsabilidade vai estar condicionada à violação de um dever jurídico preexistente, por meio do descumprimento de uma obrigação. (CAVALIERI FILHO, 2004, p. 27). Por meio desta análise se deve entender o conteúdo da culpa na conduta que contraria o pacto social constituído, e que difere da praticada pelo resto da comunidade. Desta forma, fica corroborada a responsabilidade através do erro de conduta instituído na sociedade, o qual é imputável ao provocar uma situação de dano contrária a direito (LIMA, 1999, p. 69), já seja, porque age contradizendo uma norma legal ou porque vulnera os costumes e valores daquela sociedade. Como bem reconhece a doutrina estudada só o fato de causar dano configura uma situação contrária a direito surgindo a obrigação de indenizar, tentando que o lesado possa retornar ao estado no qual se encontrava antes de tolerar o dano proferido. (MULHOLLAND, 2010, p. 41)

A culpa começa a analisar-se em dependência do tipo de responsabilidade. Para a responsabilidade subjetiva se requer de uma norma existente que seja violada com a conduta culposa; mas na responsabilidade objetiva, o agente está facultado a agir sob o imperativo de outra norma válida e vigente, porém, sua conduta infringe a boa-fé ou o comportamento padrão socialmente aceito, qualificando-se como reprovável a conduta assumida. (BODIN DE MORAES, 2003, p. 108-112) (DÍEZ PICAZO, 1999, p. 28). Configurou-se a responsabilidade civil pela falha do dever de conduta diligente denominado culpa latu sensu, através da capacidade de reconhecimento da situação danosa; e ante a conduta contrária a direito. (MULHOLLAND, 2010, p. 40)

Resulta evidente que apesar das adversidades apresentadas na evolução da responsabilidade civil, não se pode negar que, ante a proliferação de numerosos litígios por dano moral, converteu-se numa ferramenta eficaz, por meio da qual, assegura-se a justiça através do princípio constitucional da solidariedade social. (BODIN DE MORAES, 2003, p. 24), tentando-se alcançar a plena reparação da vítima de um dano, sobretudo por meio do pago pecuniário, o que sem dúvida no Brasil, é um objetivo já cumprido. Indepedentemente do tipo de teoria que seja sustentada, uma vez que, houver um ato transgressor, será colocado o sujeito lesante em uma situação de dever, configurando-se assim, o instituto da responsabilidade civil. (DA SILVA PEREIRA, 1994, p. 11).

Neste contexto, a responsabilidade se manifesta como ideia inerente ao livre desenvolvimento e à liberdade do ser humano; mas também como limitador desse 
3.

princípio e direito à liberdade, já que, começa a reger uma vez que o sujeito capacitado legalmente e em uso da sua liberdade comete um ato que transgrede ou abusa dos direitos dos quais é titular, provocando um dano moral ao próximo. Por isso, embora tenhamos direito de desfrutar nossa liberdade, estamos impossibilitados de atuar sem levar em consideração o resultado de nossos atos. ${ }^{66}$ (MULHOLLAND, 2010, p. 12). Em decorrência disto, o sujeito sempre será portador de direitos e deveres; direito de desempenhar as suas liberdades, mas também dever ou responsabilidade ante os outros, e em determinados casos pelos outros, quando na sua atuação provoque dano ao próximo.

Quando se pretende demonstrar a responsabilidade com base na culpa, a vítima deve provar a infração do agente causante, ficando o ônus probatório a seu cargo como requisito prévio para obter a reparação pretendida. Por outra parte, na responsabilidade sustentada no risco, tem que provar a existência do nexo causal, por meio da relação entre o resultado danoso e a atividade exercida pelo lesante; caindo o ônus da prova sobre o agente, já que, libera-se à vítima de confirmar suas alegações (BITTAR, 1994, p. 134). Isso significa que sempre na responsabilidade por risco a culpa do ofensor é dispensada.

Inicialmente os estudiosos do instituto da responsabilidade civil visavam a obrigação de indenizar sempre associada à presença de um ato ilícito, questão que estava unida de forma indissolúvel com a análise da conduta culposa do ofensor; porém, foram reconhecidas demandas pelos danos injustamente proferidos (MULHOLLAND, 2010, p. 17) como consequência do atuar culposo de uma pessoa, ou derivados de uma atividade lícita em específico ${ }^{67}$. Desta forma, evidencia-se uma mudança na valoração da responsabilidade civil, não já entendendo sua configuração ante a prática de um ato ilícito, mas, sua extensão no exame do ato injusto. (MULHOLLAND, 2010, p. 27). Aliás, esta novidade, ainda não se encontra inserida como via legítima, para conceder responsabilidade civil no sistema jurídico cubano. ${ }^{68}$

\footnotetext{
${ }^{66}$ A expressão "responsabilidade", cuja origem encontra-se no verbo latino respondere, significa tornar-se garantidor de algo. (...) a responsabilidade é ideia inerente ao livre desenvolvimento e à liberdade do ser humano. É esta noção que nos impede de agir como bem queiramos, sem refletir nas consequências de nossa atuação.

67 "O dano será injusto quando, ainda que decorrente de conduta lícita, afetando aspecto fundamental da dignidade humana, não for razoável, ponderados os interesses contrapostos, que a vítima dele permaneça iressarcida". Ver MOACYR PORTO. Mário: O ocaso da culpa como fundamento da responsabilidade civil. In: (BODIN DE MORAES, 2003, p. 179).

${ }^{68}$ Ver Capítulo 2, item 2.6.
} 
3.

A noção da injustiça do dano tem sido explicada por autores da doutrina brasileira, diferenciando os danos ilícitos daqueles injustos. Os primeiros acontecem no dia a dia, pelas mais simples relações entre os integrantes de toda sociedade mediante a realização de atividades cotidianas que, embora causem danos a outros não têm repercussão jurídica, precisamente por estarem autorizadas pelo sistema jurídico, não se manifestando no seu exercício um descumprimento das restrições impostas pelo próprio sistema. Nestes casos, deve a vítima acarretar o dano e suas consequências por mais desagradáveis que elas possam ser, já que, para que o lesado receba o correspondente amparo jurídico, precisa-se que o dano suportado não só seja ilícito, senão injusto. (BODIN DE MORAES, 2004, p. 175176) Autores da doutrina mais vanguardista visaram o dano injusto além da antijuricidade, precisamente para dar possibilidade à tutela de novos interesses existenciais uma vez que sejam atingidos injustamente. ${ }^{69}$

$\mathrm{O}$ argumento que deve prevalecer é que todo dano injusto tem que ter amparo em qualquer sistema, possibilitando-se a sua imediata reparação. (BITTAR, 1994, p. 33). O ato ilícito deve-se entender de forma ampla, pois, em sede de responsabilidade civil importa o ato ilícito latu sensu, que seria a contrariedade entre a conduta e a ordem jurídica estabelecida decorrente da violação de um dever jurídico pré-existente (CAVALIERI FILHO, 2004, p. 32)

$\mathrm{O}$ nexo causal constitui outro elemento fundamental da responsabilidade civil. Evidencia-se na união jurídica entre a conduta e o dano, com o fim de determinar a obrigação reparatória. É imprescindível para identificar o responsável e também para limitar o quantum indenizatório. (MULHOLLAND, 2010, p. 57). No sucessivo se avaliará o tratamento concedido no Brasil aos elementos da responsabilidade civil.

\section{2.}

\section{Definição do Dano Moral. Uma tese ainda em desenvolvimento.}

As controvérsias em relação ao dano moral começam desde seu próprio significado, existindo entre os autores da doutrina tanto brasileira como estrangeira, posições diferenciadas ao respeito. Para uns o dano é pressuposto da

\footnotetext{
${ }^{69}$ Ver C. Massimo. BIANCA, Diritto civile. La responsabilità, Milano: Giuffrè, 1995, v.5, p.584 In: (BODIN DE MORAES, 2003, p. 179)
} 
3.

responsabilidade civil, percebendo-se como qualquer lesão experimentada pela vítima em seu complexo de bens jurídicos, materiais ou morais; lesão injusta dirigida aos componentes do complexo de valores protegidos pelo direito, incluído, pois, o de caráter moral. De acordo com Carlos Alberto Bittar:

(...) danos morais são aqueles suportados na esfera dos valores da moralidade pessoal ou social, e, como tais, reparáveis, em sua integralidade, no âmbito jurídico. Perceptíveis pelo senso comum - porque ligados à natureza humana- podem ser identificados, em concreto, pelo juiz, à luz das circunstâncias fáticas e das peculiaridades da hipótese sub litem, respeitando o critério básico da repercussão do dano na esfera do lesado. (BITTAR, 1994, p. 38)

Alguns autores estabeleciam uma diferenciação na própria definição do dano extrapatrimonial considerando suas duas acepções: a primeira nomeada de vulgar, traduzida como o prejuízo que uma pessoa tolera na sua alma, no seu corpo ou seus bens; e a outra acepção é a jurídica, que seria a que interessa ao direito. Esta última parte da própria concepção da anterior, mas, prescreve o dever de indenizar ante a violação dos direitos da pessoa lesada por um fato alheio, assim, fica diferenciada a lesão que pode sofrer um indivíduo como consequência de seus próprios atos, caso no qual, manifesta-se o dano em sentido vulgar, mas não tem repercussão alguma no ponto de vista jurídico. ${ }^{70}$

Outros estudiosos do tema começam a análise no dano patrimonial para conceder uma definição ao dano extrapatrimonial. Alegam que o primeiro atinge bens integrantes do patrimônio da vítima, apreciáveis em dinheiro. Este dano se subdivide em dano emergente ou positivo, que se traduz como a efetiva e imediata diminuição no patrimônio da vítima; e o lucro cessante que é aquilo que a vítima efetivamente perdeu $^{71}$. (CAVALIERI FILHO, 2004, p. 89-90) . E o segundo seria aqueles danos não patrimoniais. ${ }^{72}$

\footnotetext{
${ }^{70}$ Assim o explica Hans Albrecht Fischer, Reparação dos danos no direito civil, trad. Antônio Arruda Férrer Correia, São Paulo, 1938, p. 7, e 9. In: (DE AGUIAR DIAS, 2006, p. 971-972)

${ }^{71}$ Artigo 402 do Código Civil: (...) as perdas e danos devidos ao credor abrangem, além do que ele efetivamente perdeu, o que razoavelmente deixou de lucrar. Posição igualmente assumida por Luis Díez-Picazo que distingue o dano emergente (perda sofrida) e o lucro cessante (o deixado de perceber), fazendo alusão à teoria da diferença, na qual o dano se concreta na diferença entre a situação valorada de forma econômica no patrimônio da vítima, que esta teria se o fato danoso não tivesse acontecido, e aquela que tem depois de acontecido o prejuízo, (DÍEZ PICAZO, 1999, p. 308-309)

${ }^{72}$ Definição do dano Moral concedida por Carpenter que entendia que o dano moral é o dano não patrimonial, a saber a dor física, dor, sensação ou a dor moral (sentimento, pesar), são objetos estranhos à órbita ou esfera do direito. In: (MELO DA SILVA, 1999, p. 331)
} 
3.

Autores mais positivos, definem o dano extrapatrimonial como a lesão ou ameaça de qualquer direito da personalidade inato do ser humano, tais como: o direito ao nome; à integridade física e à vida; e o direito à integridade moral, dentro do qual se situam outros direitos inerentes à pessoa humana, como a honra, a imagem, privacidade, dignidade, intimidade. Este próprio autor manifesta o erro de dizer que a pessoa tem direito à personalidade, já que, esta é o ponto de apoio de todos os direitos e obrigações (DA SILVA PEREIRA, 2016, p. 203-204), resultando da vulneração desses direitos a reparação por dano moral. Para outros, a própria palavra dano tem duas acepções, a lesão a um interesse material ou moral, próprio de uma pessoa, e a consequência dessa lesão, que seria o dano evento e o dano resultado. (MULHOLLAND, 2010, p. 25)

A definição do dano moral deve evidenciar-se ante a ofensa a um bem jurídico, com independência do requisito da patrimonialidade do prejuízo, de entender-se que a reparação depende de sua incidência material, termina por se recusar a indenização do dano moral puro (DA SILVA PEREIRA, 1994, p. 53 e 55). Não se ressarce à vítima porque sofreu um detrimento econômico no seu patrimônio, mas, porque foi atingida em seu bem essencial fundamental. Precisamente, neste particular radica a diferenciação entre o dano patrimonial e o extrapatrimonial, se para o primeiro a lesão se evidencia no patrimônio do lesado, o segundo se configura uma vez que esse dano incide nos aspectos existenciais da vítima, em específico, sua dignidade.

O jurista espanhol Luis Díez Picazo o associa à ideia de sofrimento, dor física ou psíquica, apresentando ampliações entre as que se encontram a perda dos prazeres da vida, o dano de desfrute, entre outros. (DÍEZ PICAZO, 1999, p. 239240). De igual forma, não concebe a lesão dos direitos subjetivos como pressupostos do dano, pois, para ele, essa construção restringe a própria definição de dano moral. (DÍEZ PICAZO, 1999, p. 291-292) O jurista reduz o dano extrapatrimonial ao sofrimento ou perturbação de caráter psicofísico no âmbito da pessoa, no qual a indenização só se justifica quando o dano atinge os direitos da personalidade (DÍEZ PICAZO, 1999, p. 328-329).

Por outra parte, alguns autores da doutrina brasileira fundamentam o dano através da repercussão anímica da vítima, identificada na dor proferida medida pelo resultado moral da lesão a interesse juridicamente protegido. (MONTEIRO FILHO, 2000, p. 39-40), desta forma, identificam o dano moral com suas 
3.

possíveis decorrências; entendendo sua configuração quando a vítima manifesta a angustia, dor, sofrimento, tristeza ou humilhação, ou seja, sensações e emoções negativas. (LOUZADA BERNARDO, 2005, p. 77-78)

Contrariando essa posição, o autor Anderson Schreiber entende que o dano moral consiste na lesão a qualquer atributo da personalidade humana sejam ou não reconhecidos pelo Código Civil. (SCHREIBER, 2011, p. 16). Após a Constituição de 1988, não mais se restringe a pretium doloris, senão que também percebe-se a figura no ataque ao nome, à imagem da pessoa, (COUTO DE CASTRO, 2005, p. 21). A professora Maria Celina Bodin de Moraes denuncia a prática arbitrária que, no Brasil, faz o magistrado ante um caso de dano moral, abrangendo-o como um mal que se deriva de sentimentos de vexame, tristeza, dor, humilhação, transgredindo o bem-estar da pessoa atingida, sendo suficiente o dano in re ipsa. (BODIN DE MORAES, 2003, p. 51). De ser este o entedimento, então seria suficiente conceitualizar o dano extrapatrimonial como mal evidente, questão criticada pela autora antes citada, quem percebe a confusão do dano com suas sensasões ou emoções desagradáveis, que podem ou não apresentar-se uma vez que este ocorre. Emoções que ainda certas, podem ser justificadas ao não derivarse de um dano considerado injusto (BODIN DE MORAES, 2003, p. 130-131), devendo a vítima carregar com as consequências do evento danoso.

$\mathrm{O}$ antes criticado pela autora pode-se comprovar com o depoimento do jurista Sergio Cavalieri Filho, quem assevera a existência de dano moral suscetível de reparação quando se manifestam de forma anormal emoções que interferem intensamente no comportamento psicológico do lesado; sentimentos de dor, vexame, sofrimento, ou humilhação que causam aflições, angústia e desequilíbrio em seu bem-estar. Para o autor, o que corresponde é discernir entre o mero dissabor, aborrecimento, mágoa, irritação ou sensibilidade exacerbada, de outras circunstâncias em que estes mesmos elementos se manifestam de forma intensa. $\mathrm{O}$ dano moral existe in re ipsa deriva inexoravelmente do próprio fato ofensivo, provada a ofensa ipso facto, está demonstrado o dano moral à guisa de uma presunção natural. (CAVALIERI FILHO, 2004, p. 98 e 101)

Este entendimento foge da própria natureza da figura em estudo, não se pode assemelhar o dano com suas possíveis consequências, tenha-se em conta que, o universo humano é complexo, podendo existir casos em que estas sensações podem ser fingidas com o fim de receber uma reparação; e embora 
3.

esses sentimentos sejam certos, quando ocorre um dano moral, como, por exemplo, a morte de um familiar, de assumir este posicionamento, todas as pessoas que manifestem de forma anormal as consequências da lesão estariam legitimadas. O que corresponde é analisar se o dano moral provém da injusta violação de uma situação jurídica subjetiva extrapatrimonial, que tem sua razão de ser, nos preceitos constitucionais, principalmente no princípio da dignidade da pessoa humana. Assim o expõe a professora Maria Celina Bodin de Moraes:

(...) tanto será dano moral reparável o efeito não-patrimonial de lesão a direito subjetivo patrimonial (hipótese de dano moral subjetivo), quanto a afronta a direito da personalidade (dano moral objetivo), sendo ambos os tipos admitidos no ordenamento jurídico brasileiro. (BODIN DE MORAES, 2003, p. 157)

Sempre que se exerça um direito de forma injusta que incida negativamente sobre a dignidade humana, corresponderá a compensação; tomando em consideração a funcionalidade do ordenamento jurídico como um todo, brindando proteção ao direito existencial preferentemente, naqueles casos em que o conflito seja contra um direito de outra índole. ${ }^{73}$ Uma vez analisados os direitos em questão, estabelecendo uma preponderância entre o direito exercido pelo lesante e aquele direito existencial transgredido, resulta justo e razoável o correspondente ressarcimento da vítima por dano moral. (BODIN DE MORAES, 2003, p. 175-179). Sustentam este entendimento vários autores que desde há muitos anos vêm argumentando que o conceito de dano moral não pode estar determinado ante a lesão a um direito da personalidade, nem tampouco se deve restringir à transgressão de um direito subjetivo, senão que deve estar determinado pela violação do princípio da dignidade da pessoa humana. ${ }^{74}$

A dignidade humana vai ser a guia para a consecutiva proposição de interpretações nos ordenamentos em exame. Como se apreendeu, o conceito do

\footnotetext{
${ }^{73}$ Percebe-se a necessidade do dano injusto para que fique configurada a reparação do dano moral. (BITTAR, 1994, p. 15-16,25). (...) havendo dano, produzido injustamente na esfera alheia, surge a necessidade de reparação (...).

${ }^{74}$ Neste sentido destacam-se V. Paulo. Luiz NETTO LÔBO, Danos Morais e direitos da personalidade, Revista Trimestral de Direito Civil, n.6, p.79 e ss., abr./jun. 2001. J. Aguiar dias, Da responsabilidade civil, cit., v. II, p.720. Jean, Claude. MONIER indica a obra de Raymond. SALEILLES como inspiradora dessa posição, acolhida por R. NERSON, La Protection de la personne et ses droits e A. DECOCQ. René. SAVATIER e Louis. JOSSERAND, segundo J. C. MONIER, Personne humaine et responsabilité civile, p.65) In: (BODIN DE MORAES, 2003, p. 184,186-187)
} 
3.

dano moral tem ficado condicionado, desde seu surgimento, pela própria mudança da sociedade e os novos desafios apresentados pela ciência e o progresso, até o ponto de considerar à pessoa humana, após muitos séculos de marginalização e exploração, como o elemento fundamental do ordenamento jurídico, percebendo o dano moral na conduta lícita ou ilícita que provoque lesão grave e injusta, vulneração ou violação, daqueles componentes inerentes à personalidade e que conformam o princípio da dignidade humana (direito à integridade psicofísica da pessoa, imagem, privacidade, intimidade, corpo, honra, nome, etc.).

Por meio da filosofia Kantiana do imperativo categórico, consagraram-se os direitos e valores do ser humano como os principais elementos que deve levar em conta não só o legislador, o poder judicial e demais órgãos do Estado, senão também, a sociedade como um todo na realização cotidiana dos seus mais simples atos até os mais complexos, que podem incidir direta ou indiretamente na pessoa alheia. Dessa forma, devemos procurar o nosso próprio bem-estar, mas, sempre levando em consideração a felicidade alheia, afastados de toda prática egocêntrica que só pode-nos beneficiar a expensas dos demais. "Assim age de modo que a máxima de tua ação possa tornar-se uma lei universal” (KANT, 2003)

\section{3. \\ O Princípio da Dignidade da Pessoa Humana como fundamento constitucional do Direito de Danos}

Contrariamente à tese hobessiana que definia o homem como um lobo para o outro homem, ao agir movimentado por um sentimento egoísta e estratégico (HOBBES, 2003), e em resposta dos massacres acontecidos, principalmente, na Segunda Guerra Mundial; surgiram importantes acontecimentos e leis, celebrados fora da região; ou seja, fora de continente Latino-Americano, que vieram a transformar o modo de pensar e de contextualizar a pessoa humana, agora significando o principal expoente a quem o Estado deve brindar proteção.

Entre estes corpos legais de grande envergadura se encontra a Carta Magna de 1215, que denunciou os abusos de autoridade surgindo daí o habeas corpus; a Declaração dos Direitos do Homem e do Cidadão de 1789 proclamada pela Revolução Francesa, à que se lhe adiciona o Bill of Rights pronunciado nos Estados Unidos em 1791; a Carta das Nações Unidas de meados do século XX 
3.

que suprimiu os abusos originados na Segunda Guerra Mundial. Todos estes, dentre outros corpos legais, propiciaram o entendimento da dignidade humana como o centro de atenção que devia imperar em todo Estado Democrático de Direito. (DA SILVA PEREIRA, 2016, p. 201-202) No Brasil, esta concepção progressista se solidificou com a Constituição Federal de 1988, ao consagrar-se como Estado Democrático de Direito no seu próprio preâmbulo e no artigo 1. III estabeleceu como postulado primeiro o princípio da dignidade humana ${ }^{75}$. Os fundamentos da Lei Suprema do Brasil são a dignidade humana, a igualdade substancial e a solidariedade social. (BODIN DE MORAES, 2003, p. 110)

Como bem se sabe, no Brasil também foi instaurada uma ditadura sob o regime militar (BODIN DE MORAES, 2003, p. 83), muito diferente à existente em Cuba, uma vez que em termos sociais e humanos existia um detrimento considerável da pessoa e de seus bens mais prezados (a vida e a liberdade). Por esta razão, a Constituição de 1988 constituiu um rompimento com os laços autoritários que existiam no passado, constituindo, a meu ver, um texto incentivador do novo constitucionalismo latino-americano. A norma suprema brasileira enaltece como valores da ordem jurídica o princípio da dignidade humana, de igual forma realça os ideais de igualdade, liberdade, segurança, propriedade e justiça sob a caraterização do Estado Democrático do Direito. (BITTAR, 1991, p. 15-16). Através da proteção constitucional da cláusula da dignidade humana, autores vanguardistas assumem a superação da dicotomia direito público e direito privado (TEPEDINO, 2004, p. 53) e em consecutivo a oportuna reparação do dano moral; especificamente o consignado no artigo $5 . \mathrm{V}{ }^{76}$ em adição ao estipulado no Código de Proteção e Defesa do Consumidor (Lei 8.078 de 11 de setembro de 1990) em seu art.6, VI, VII ${ }^{77}$.

\footnotetext{
${ }^{75}$ Ver (BRASIL. CONSTITUIÇÃO DA REPÚBLICA FEDERATIVA DO BRASIL, de 5 de outubro de 1988, art. 1), ficando consagrado no art. 11 do Código Civil brasileiro (BRASIL. Lei $\mathrm{N}^{\circ} 10.406$, de 10 de janeiro de 2002, art. 11)

${ }^{76}$ Artigo $5 \mathrm{~V}$ da Constituição Federal: (...) é assegurado o direito de resposta, proporcional ao agravo, além da indenização por dano material, moral ou à imagem.

${ }^{77}$ Código de Proteção e Defesa do Consumidor (Lei 8.078 de 11 de setembro de 1990), art. 6. VI e VII: São direito básicos do Consumidor (...) a efetiva prevenção e reparação de danos patrimoniais e morais, individuais, coletivos e difusos. (...) o acesso aos órgãos judiciários e administrativos com vistas à prevenção ou reparação de danos patrimoniais e morais, coletivos e difusos, assegurada a proteção jurídica, administrativa e técnica aos necessitados.
} 
3.

Ante a violação do princípio constitucional, previamente citado, deve ser interpretado o dano moral e a iniludível exigência de que, aqueles prejuízos que atinjam os componentes existenciais da pessoa humana devem obter a oportuna resposta do sistema legal, procurando a imediata reparação da vítima através das vias que resultem pertinentes. Dessa forma, surge o direito de danos, destinado a suprir a desproteção que inicialmente tinha a pessoa atingida ante a existência de um dano que transgredia sua dignidade. A partir de então, este direito configura-se como instrumento de efetivação dos valores constitucionais que integram o princípio geral da dignidade humana (MULHOLLAND, 2010, p. 68), vulnerações que podem configurar-se tanto nos elementos materiais quanto nos morais.

Mediante a valoração dos subprincípios da dignidade da pessoa humana: integridade psicofísica, igualdade, liberdade e solidariedade; e com alusão às ações que se destinem a sua vulneração, justifica-se a plena reparação da vítima de um dano. ${ }^{78} \mathrm{~A}$ interpretação do princípio geral da dignidade humana demanda a reparação dos danos de forma íntegra. Hoje em dia, a pessoa encontra-se no patamar do ordenamento, não vista como um sujeito que não deve obediência e que pode exercer seus direitos de acordo a seu livre alvedrio, senão que essa liberdade vai estar condicionada ao respeito por si mesma e ao reconhecimento dos outros membros da sociedade. (PERLINGIERI, 1997 , p. 298-299)

Precisa-se ponderar e sopesar o direito de liberdade da pessoa com o dever de solidariedade social ${ }^{79}$. (BODIN DE MORAES, 2003, p. 108) Isso significa que, em alguns casos, concretamente analisados, a liberdade de uma pessoa tem que ceder pelo bem comum e social, precisamente porque o princípio a ser enaltecido em todo Estado é o da dignidade da pessoa humana, justificando-se desta forma o dever de não causar danos a outros, mas também, a possibilidade da solidarização na reparação desses danos (DE AGUIAR DIAS, 2006, p. 24-25). Contrariamente aconteceria se a dignidade da pessoa humana fosse vulnerada de

\footnotetext{
${ }^{78}$ Assim o explica a professora Maria Celina, apontando que os princípios jurídicos da igualdade, da integridade física e moral - psicofísica-, da liberdade e da solidariedade derivam-se dos postulados da dignidade humana, mediante a qual o sujeito moral (ético) reconhece a existência dos outros como sujeitos iguais a ele, merecedores do mesmo respeito que ele detém, e por tanto, tem a garantia de não vir a ser marginalizado. (BODIN DE MORAES, 2003, p. 85)

${ }^{79} \mathrm{O}$ direito da solidariedade social surgiu como consequência da segunda Grande Guerra no século XX. Foi a noção de "crime contra a humanidade", até então inexistente, que possibilitou que se começasse a pensar na humanidade como uma coletividade, merecedora de proteção jurídica (...) nesse novo cenário, o valor fundamental deixou de ser a vontade individual, o suporte fático-jurídico das situações patrimoniais que importava regular, dando lugar à pessoa humana e à dignidade que lhe é intrínseca. (BODIN DE MORAES, 2003, p. 109)
} 
3.

forma geral, especificamente pelo Estado, dado seu amplo arcabouço de poder; nestes casos, não seria a solidariedade social a que se estaria ponderando e sopesando, senão o próprio interesse estatal.

Por estes elementos, a reparação do dano moral e sua inteira interpretação devem basear-se no fundamento da dignidade da pessoa humana, pois, tanto os direitos subjetivos e os direitos da personalidade encontram-se inseridos nesse princípio geral aludido, cuja tutela demanda seu imperativo cumprimento e proteção. Por isso, não precisamos que se encontrem reguladas todas as hipóteses geradoras de dano moral, como tampouco resulta imperiosa a estipulação legal de sua reparabilidade, já que, é suficiente a tutela constitucional da dignidade humana, inserida tanto em Cuba como no Brasil como fundamento do Estado. ${ }^{80}$

\section{4. \\ Identificação e Reparação do Dano Moral no Brasil.}

No sistema jurídico brasileiro, de igual forma, existiram diversos critérios contrários e favoráveis da reparação pecuniária do dano moral. A doutrina e a jurisprudência nem sempre aceitaram a concessão de uma quantia monetária em termos de compensação. As correntes que negavam a presença do elemento econômico sustentavam que: não se lhe podia atribuir preço à dor; que o dinheiro se representava como contrário à moral, em aspectos como a honra, a dor, etc.; entendiam um absurdo sistematizar em concreto os reflexos negativos que experimentavam as pessoas, assim como, a demonstração prática desses reflexos; adicionando a impossibilidade da prova dos danos morais e o arbitramento que lhe era concedido ao juiz na fixação desse valor reparatório. (BITTAR, 1994, p. 76) (CAVALIERI FILHO, 2004, p. 95)

Posteriormente foi acolhida a tese da reparabilidade dos danos morais reflexos, através dos quais se exigia a necessidade de uma consequência patrimonial. Posição que de certa forma, limitava e negava a proteção do dano moral propriamente dito. Já com posterioridade esta noção completou no Brasil o

\footnotetext{
${ }^{80}$ Eu quero que a lei primeira de nossa República seja o culto dos cubanos à dignidade plena do homem. CUBA, Constitución de la República de Cuba, 24 de febrero de 1976, Preámbulo e art. 1 e 9 a).

A República Federativa do Brasil (...) constitui-se em Estado Democrático de Direito e tem como fundamentos: (...) a dignidade da pessoa humana. Constituição da República Federativa do Brasil de 5 de outubro de 1988, arts. 226.7; 227; 230;
} 
3.

ciclo evolutivo instituindo-se a teoria da reparabilidade plena. (BITTAR, 1994, p. 86). Existindo hoje a inteira reparação da vítima de um dano moral com amplo reconhecimento civil, constitucional e judicial.

A própria consciência social fez mudar a antiga concepção do dano moral, uma vez que, não se considerava justo que uma pessoa lesada nos seus aspectos existenciais permanecesse sem nenhuma proteção pelo sistema onde se encontrava inserida. Desta forma, no Brasil, tornou-se inconcebível ignorar o dano moral fazendo-se iminente o ressarcimento do lesado, aliás, o que corresponde é verificar a existência dos elementos da responsabilidade civil e a injustiça do dano suportado ${ }^{81}$ adotando-se a indenização econômica não pelo sofrimento irreparável, senão como compensação à vítima (SCHREIBER, 2007, p.123 e 124).

O dano extrapatrimonial no ordenamento brasileiro se qualifica, em tese, por meio da configuração dos elementos da responsabilidade civil: o dano, a culpa, o risco e o nexo causal. O valor da dignidade humana servirá de bússola naqueles casos em que se evidencie uma atividade danosa, por isso, pode-se afirmar que quando o resultado do dano seja o suficientemente grave e injusto, fica configurado de fato um dano moral e como consequência é imperiosa sua reparação. Este precisamente é o objetivo traçado pelo artigo $3^{\circ}$ da Constituição, ao propender pela construção de uma sociedade justa, livre e solidária que à vez, culmine com as desigualdades sociais, demandando do Estado uma atuação ativa destinada à realização da justiça distributiva e da igualdade substancial. (BRASIL. Constituição da República Federativa do Brasil, de 5 de outubro de 1988, art. 3).

A responsabilidade civil encontra-se estipulada a partir do Título IX, Capítulo I da lei civil brasileira, regulando a obrigação de indenizar, primeiramente por conduta ilícita, rejeitando o elemento culpa e brindando-lhe mais protagonismo ao risco, percebendo-se a responsabilidade civil por fatos de terceiros, assim como por danos ocasionados por animais. ${ }^{82}$ A vítima de um dano, sempre que fique legitimamente demonstrado, pode solicitar a acumulação de

\footnotetext{
${ }^{81}(\ldots)$ O que mudou foi a consciência coletiva acerca do conceito de justiça: o que antes era tido como inconcebível passou a ser aceitável, e de aceitável a evidente. Se era difícil dimensionar o dano, em questão de poucos anos tornou-se impossível ignorá-lo. Se era imoral receber alguma remuneração pela dor sofrida, não era a dor a que estava sendo paga, mas sim a vítima, lesada em sua esfera extrapatrimonial, quem merecia ser recompensada pecuniariamente, para assim desfrutar de alegrias e outros estados de bem-estar psicofísico, contrabalançando os efeitos que o dano causara em seu espírito. (BODIN DE MORAES, 2003, p. 147)

${ }^{82}$ Ver nos artigos 927-954 (BRASIL. Lei No .10 .406 , de 10 de janeiro de 2002)
} 
3.

danos morais e materiais no mesmo processo, (BITTAR, 1994, p. 229) evitandose desta forma, a possível sentença contraditória que possa emitir-se ante a apresentação de demandas independentes.

Alguns dos juristas que fazem aportes consideráveis nesta área do direito, entendem que a reparação do dano moral tem caráter compensatório ${ }^{83}$. Nestes casos, o direito atingido não seria restituído, como também resulta improvável que a vítima seja colocada novamente no lugar em que se encontrava antes de suportar o fato danoso, porém, o dinheiro é capaz de proporcionar uma satisfação que, na medida do possível, amenize a sensação experimentada; isto, não significa que se levará a efeito a reparação tendo em consideração a equivalência ${ }^{84}$ entre o valor do direito atingido em abstrato com a quantia que posteriormente se concederá Esse argumento iria contra toda lógica, pois resulta impossível colocar valores pecuniários a direitos existenciais, e inerentes ao ser humano, que se consideram superiores a outros bens que logram suprimir-se em uma suma monetária.

De forma contrária, outros autores entendem que além do caráter compensatório manifesta-se o punitivo destinado ao castigo do ofensor, questão que após será analisada ${ }^{85}$. O maior problema que vem acontecendo no Brasil em alusão ao tratamento do dano moral deriva-se da ampla proliferação de casos apresentados exigindo reparação econômica, constituindo-se desta forma, uma desmoralização destes danos e da cláusula da dignidade humana, pela existência da chamada indústria do dano moral. (BODIN DE MORAES, 2003, p. 38)

Devido ao amplo poder concedido aos tribunais, a ausência de critérios unificadores da função judicial, e a errônea definição que do dano extrapatrimonial têm a maioria dos encarregados de ministrar justiça; existe uma proliferação qualitativa de demandas exigindo reparação pecuniária por dano moral. Anderson Schreiber tende a definir esta situação como a erosão dos filtros tradicionais da reparação pela perda da importância da culpa e da prova do nexo

\footnotetext{
83 (...) O que é mister é a reparação pelo critério da equivalência econômica, num caso, ou pelo critério da simples compensação, de mera satisfação, como o queiram, no outro. (MELO DA SILVA, 1999, p. 561) (MULHOLLAND, 2010, p. 32)

${ }^{84}$ Foi Josserand, Dei Contrati di Trasporto, trad. Italiana de Giannini, 1926, Milão, p.945, n.907, quem advertiu de que se devia renunciar à estulta pretensão de estabelecer uma perfeita simetria entre o dano e sua reparação. (MELO DA SILVA, 1999, p. 560)

${ }^{85}$ Nesta posição coincidem vários autores da doutrina brasileira (MONTEIRO FILHO, 2000, p. 111) (CAVALIERI FILHO, 2004, p. 95) Silvio Rodrigues, Direito Civil: responsabilidade civil, v.4, 20. Ed. São Paulo: Saraiva, 2003, p.4. In: (DE ANDRADE LEVY, 2012, p. 186), (BITTAR, 1994, p. 280) (DA SILVA PEREIRA, 1994, p. 55 e 317) Ver Item: 3.6.
} 
3.

causal, traduzido pelo desgaste do interesse do juiz em relação aos elementos que justificam a interposição de uma obrigação. (SCHREIBER, 2005, p. 56)

No estágio atual, identificar os danos morais ressarcíveis resulta uma tarefa muito mais difícil devido à grande propagação das demandas apresentadas ante a violação de direitos existenciais, isso acontece, pela inclusão da responsabilidade objetiva; mas também está associado à interpretação que hoje em dia faz os juízes em relação ao conceito de dano moral, os casos em que deve ser ressarcido e a soma concedida em cada litígio; sem entrar a conhecer de outras vias pelas que pode ficar compensado o lesado, resultando, mais usual, a indenização econômica. Assim, os tribunais brasileiros têm concedido tutela judicial a novas espécies de danos. (SCHREIBER, 2005) (SCHREIBER, 2007, p. 79).

Esta situação tem uma dupla consideração, positiva por tentar responder ao imperativo criado pelo Estado Democrático de Direito de colocar a pessoa humana no cerne do sistema, mas, em contraposição tem um caráter negativo, sobretudo, porque os juízes na sua tarefa de identificar os danos morais e sua consecutiva reparação, concedem amparo à maioria dos casos que resolvem; situação que traz consigo a propagação dos assuntos desta índole, criando-se na sociedade um sentimento de interesse que foge dos parâmetros da boa-fé, buscando alternativas ou vias para alcançar um benefício patrimonial. Embora isso não possa ser identificado em todos os casos deliberados pelo órgão judicial brasileiro, não é menos certo que, nos últimos tempos tem se apresentado demandas cujas pretensões resultam pouco sérias, ao não provar a gravidade do prejuízo que dizem padecer seus promoventes. ${ }^{86}$

Com a isenção da culpa, nos danos provenientes de riscos, aumentou consideravelmente o fluxo de ações por danos morais. De igual forma, o tribunal em aras de atender ao reclamo da vítima termina por assentir a sua petição, para isso, adota várias teorias da causalidade como são: a teoria da causalidade direta e imediata; a teoria da equivalência das condições; e tantas outras de evolução mais recente, mediante as quais, termina por fundamentar sua decisão em favor do lesado. Expressões como causalidade adequada e causalidade eficiente têm sido

${ }^{86}$ Ver no item 3.6. 
3.

empregadas em procedimentos racionais que refletem o uso de outras teorias, como a subteoria da necessariedade. (SCHREIBER, 2005, p. 53)

Nas teorias adotadas pelos tribunais brasileiros, encontra-se a Teoria da equivalência dos antecedentes (das condições): por meio da qual, tomam-se em consideração todas as condições que concorreram para o resultado; todas têm a mesma relevância e todas se equivalem. Esta teoria é chamada de conditio sine qua non, ou de equivalência das condições. Critica-se porque a partir de sua interpretação entrariam a responder pelo dano acontecido muitas pessoas, ainda que diretamente não participassem no exercício do evento danoso.

Também são utilizadas: a Teoria da causalidade adequada, mediante a qual se considera causa aquele fato antecedente, necessário e adequado à produção do resultado. Tomar-se-ia aquela causa que fora mais apropriada a produzir o evento. O problema está em saber qual, entre várias condições, será a adequada. A Teoria da Causa Eficaz, cuja causa é a condição mais eficaz, segundo critério quantitativo. A Teoria do Equilíbrio, através da qual se determina a causa pelo rompimento do equilíbrio entre as condições positivas e negativas que fizeram aparecer o resultado; teorias que se encontram ultrapassadas na atualidade. (CAVALIERI FILHO, 2004, p. 67-68)

Assim como estas, existem outras teorias da causalidade ${ }^{87}$ utilizadas sem nenhum critério específico pelos tribunais brasileiros. A teoria acolhida pelo Código Civil atual deriva-se da interpretação do art. 403, do qual, pode-se coligir a convergência das teorias da causalidade adequada e do dano direto e imediato, misturando-se os fundamentos das teorias mais ampliadas pela doutrina brasileira. (MULHOLLAND, 2010, p. 188-194) As diferentes teorias de causalidade aceitas pelos tribunais na fundamentação dos litígios existenciais, não concedem solução definitiva ao problema do nexo causal, culminando este processo com a responsabilização do incriminado, ainda que não esteja demonstrado o nexo de causalidade; ou evidenciando-se uma análise escassa desse elemento, sendo emitidas decisões injustas pelo poder judicial. (SCHREIBER, 2007, p. 59-61)

Existe uma presunção da culpa e da causalidade, nos danos em que estão implicadas várias pessoas, sem que se conheça com certeza o causante do prejuízo

\footnotetext{
${ }^{87}$ Teoria da equivalência das condições; Teoria da causalidade adequada; Teoria do dano direito e imediato; Teoria do escopo de proteção da norma violada; Teoria da causa eficiente e da causa preponderante; Teoria da causa próxima; Teoria da imputação objetiva. Ver In: (MULHOLLAND, 2010, p. 135-188)
} 
3.

proferido, adota-se a teoria da causalidade alternativa que atribui à conduta de todos os envolvidos em conjunto a relação da causalidade com o dano gerado, sem sequer fazer prova concreta desse nexo causal, tentando delimitar o principal responsável do ato lesante. Da mesma forma, acontece com a queda de objetos de condomínios de apartamentos, toda vez que, a jurisprudência orientou atribuir a causa ao condomínio como um todo. ${ }^{88}$

Uma vez revelados os problemas em relação à culpa e ao nexo causal, os tribunais brasileiros, para poder identificar os casos de danos morais reparáveis, valoram o prejuízo criado, pois o dano extrapatrimonial é considerado in re ipsa, pelo qual, terminam reparando as consequências dos danos, empregando critérios como a prova da dor, vexame, sofrimento ou humilhação (SCHREIBER, 2007, p. 124), sem entrar a conhecer sobre a injustiça da lesão. Forma de proceder que não resulta apropriada em virtude das garantias processuais que devem ser aplicadas para que um processo judicial seja justo. O dever não é ressarcir a vítima em todos os litígios que sejam expostos, o que se deve exercer é a justiça, delimitando aqueles casos dignos de reparação, mas também, distinguindo os danos graves, daqueles menos graves e inclusos, diferenciando-os dos danos que devem ser toleráveis. Não se devendo conceder a reparação quando não se configurem eficazmente os elementos da responsabilidade civil. (SCHREIBER, 2007, p. 6)

De acordo com a valoração previamente feita, pode-se situar o ordenamento brasileiro, nos sistemas de reparação atípico ou aberto, no qual, o legislador prevê cláusulas gerais que determinam uma guia na atuação do juiz, mas que, deixam a seu livre arbítrio a consideração final da lide, decidindo sem prescrição legal o outorgamento de tutela dos diferentes assuntos submetidos a sua determinação, (BRASIL. Lei No 10.406, de 10 de janeiro de 2002, art. 953, parágrafo único e art. 954) mas essa discricionariedade demanda a vigilância dos parâmetros que integram a responsabilidade civil, ao contrário do que está acontecendo no sistema judicial brasileiro e que é denunciado firmemente pelos autores mais vanguardistas da doutrina. (SCHREIBER, 2007, p. 131) Desta forma, revelam-se

\footnotetext{
${ }^{88}$ Ver cita da decisão do TSJ no âmbito do recurso especial 64682/ RJ, 10/11/1998 In: (SCHREIBER, 2005, p. 55)... A flexibilidade dos tribunais na exigência da prova do nexo causal tem dado margem na doutrina a inúmeras novas teorias sobre causalidade flexível, causalidade virtual, causalidade moral, e outras teses que vão interferindo na atual concepção do nexo causal. Argumento reafirmado pelo artigo 938 do Código Civil brasileiro. (BRASIL. Lei $\mathrm{N}^{\circ} 10.406$, Código Civil do Brasil de 10 de janeiro de 2002).
} 
3.

as dificuldades na labor judicial à hora de qualificar um dano moral, pois de forma contrária, parte da doutrina brasileira vem advogando pelo tratamento da figura em estudo de forma diferente, sob o lema de que todo dano não é reparável, nem todos os danos configuram dano moral. (BITTAR, 1994, p. 24)

Através da precária observância dos elementos da responsabilidade civil por parte do poder judicial competente nesta matéria, configura-se a injustiça a favor do hipotético lesante, o qual é vencido sem juízo justo, ao não poder corroborar sua inocência e suportando de forma individual os ônus da reparação. Com essa prática, o poder judiciário brasileiro além de incorrer em injustiça, promove a apresetanção de demandas, já que, resulta um exercício costumeiro a reparação da vítima com independência da minuciosa valoração dos elementos da responsabilidade civil $^{89}$ o que se traduz em uma iniquidade desmesurada, semelhante quanto manter a consecução do elemento danoso sobre o lesado. (SCHREIBER, 2007, p. 7), por isso, pode-se afirmar que a sentença emitida nestes casos é arbitrária, quebrando-se a obrigação de aplicar justiça em nome do povo, tal e como prevê o preâmbulo da Lei Suprema. (BRASIL, Constituição da República Federativa do Brasil, de 5 de outubro de 1988, Preâmbulo)

A diferença da valoração que faz o poder judiciário, na qualificação do dano corresponde determinar inicialmente a existência de um dano que deve atingir qualquer componente da dignidade humana, esse dano tem que ser injusto transgressor do dever jurídico pré-estabelecido na sociedade ou de uma norma estipulada, do contrário não acarreta reparação. Posteriormente, deve-se investigar o nexo causal, pois se precisa analisar se a conduta do lesante foi capaz de causar o dano, do contrário, não está compelido juridicamente a reparar esse prejuízo. Só a partir desta valoração determina-se e comprova-se a culpabilidade ou não do lesante. (MULHOLLAND, 2010, p. 81) (CAVALIERI FILHO, 2004, p. 65)

A culpa e o risco não passam a ser tidos em consideração para determinar a existência de um dano moral, precisa-se primeiro determinar a sua injustiça (MULHOLLAND, 2010, p. 27) O juízo se volta para o segundo obstáculo à

${ }^{89}$ Desta forma, agem em contraposição com o estabelecido no artigo 944 do Código Civil Brasileiro, que estipula que a indenização se mede pela extensão do dano, concedendo ao juiz a faculdade de poder reduzir a indenização quando a valoração dos elementos da responsabilidade civil assim o aconselhe, pela excessiva desproporção entre a gravidade da culpa e o dano. 
3.

reparação, ou seja, a demonstração do nexo de causalidade, identificando-se, segundo a doutrina mais inovadora, uma pequena perda dos filtros do ressarcimento dos danos, por força de um fenômeno que pode ser designado como flexibilização do nexo causal (SCHREIBER, 2007, p. 48). Por isso é imprescindível selecionar os interesses merecedores de tutela para assim evitar a imensa propagação de litígios por dano moral que estão sendo apresentados ante sede judicial, cujo ressarcimento também é concedido sem maiores complicações. ${ }^{90}$ Estas novas espécies de dano fazem nascer o certo temor previsto por Stefano Rodotà de que: "a multiplicação de novas figuras de danos venha a ter como únicos limites a fantasia do intérprete e a flexibilidade da jurisprudência" 91

O princípio de que a reparação do dano será sempre a mais completa possível, em todo caso priorizando à vítima, tem sido defendido por parte da doutrina brasileira e estrangeira ${ }^{92}$ como resposta precisamente à nova noção da dignidade humana. (DE AGUIAR DIAS, 2006, p. 1000). Resulta perfeitamente possível a utilização de outros mecanismos ${ }^{93}$, através dos quais, pode-se exercer uma inteira reparação do dano moral, não só ficando restringido à reparação pecuniária; já que, podem existir casos em que para o lesado importe mais a divulgação do arrepentimento do ofensor como meio da reparação do prejuízo. Visão seguida pelo professor Luis Díez-Picazo em relação ao conteúdo da pretensão indenizatória encaminhada ao ressarcimento integral da vítima. ${ }^{94}$

\subsection{1.}

\section{Partes integrantes no litigio por danos morais}

São responsáveis por danos morais todas as pessoas naturais ou jurídicas, de direito público ou privado, nacionais ou estrangeiras que estejam relacionadas diretamente com o fato que ocasionou o prejuízo. Neste contexto também se inclui a responsabilidade por fato próprio ou de terceiros, ou de animal, etc. (BITTAR, 1994, p. 137). Ficando de igual forma compreendida a responsabilidade do

\footnotetext{
${ }^{90}$ Ver item 3.6

${ }^{91}$ Stefano Rodotà. II problema dela responsabilità civile. Milano: Giuffrè, 1967, p.23) In (SCHREIBER, 2005, p. 60)

${ }^{92}$ Ver artigo 402 do Código Civil Brasileiro e o art. 1149 do Código Civil Francês.

93 Podem-se observar, em razão das particularidades da situação fática, e em particular, pela natureza da obrigação envolvida, prestações outras, como, por exemplo, em caso de fungibilidade da obrigação, a respectiva substituição; a satisfação in natura; a retratação, em hipótese de desrespeito ou de injúria pessoal. (BITTAR, 1994, p. 63)

${ }^{94}$ Ver no item 2.1. Pág. 15.
} 
3.

Estado $^{95}$. E, no caso da existência de dois ou mais agentes responsáveis ante um dano extrapatrimonial, então, estão submetidos à regra da solidariedade prevista nos artigos 264, 932 e 942 do Código Civil.

Pode exigir a reparação por dano moral, toda pessoa que de forma direta suporte os reflexos negativos do fato prejudicial. Agora bem, corresponde delimitar até onde pode ser reclamada essa reparação. O jurista Sergio Cavalieri propõe como solução partir do princípio da razoabilidade, tomando em consideração o art. 496 do Código Civil português que tem regra expressa sobre esta questão ${ }^{96}$. Propondo também adotar a regra estabelecida no art. 948 II do Código Civil brasileiro ${ }^{97}$ relativo ao dano material, como norma analogicamente aplicável na delimitação da indenização por dano moral. A partir daí o dano moral só poderá ser pleiteado por pessoa alheia à estabelecida na lei, devendo mediar prova de convivência próxima e constante que se tinha com o causante, art. 20 parágrafo único $^{98}$ (CAVALIERI FILHO, 2004, p. 102).

Segundo alguns autores ante o dano moral ou material que seja causado no âmbito familiar, dispensa-se qualquer demonstração além da própria morte do parente. Fora deste caso, precisa-se demonstrar que este realmente se verificou. (DE AGUIAR DIAS, 2006, p. 1059) De igual forma, prevê-se a possibilidade de que o herdeiro da pessoa que falece, no curso da ação solicitando dano moral, possa vir a suceder ao de cujus no processo, já que, neste caso não está herdando o dano moral, senão a respectiva reparação, a que uma vez concedida por parte do tribunal, corresponde por legítimo direito ao herdeiro, quem assume tantos as ganâncias como as dívidas do causante. (CAVALIERI FILHO, 2004, p. 103-105)

95 (BRASIL. Constituição da República Federativa do Brasil, de 5 de outubro de 1988, art. 37)

${ }^{96}$ Artigo 496: 1. Na fixação da indemnização deve atender-se aos danos não patrimoniais que, pela sua gravidade, mereçam a tutela do direito. 2. Por morte da vítima, o direito à indemnização por danos não patrimoniais cabe, em conjunto, ao cônjuge não separado judicialmente de pessoas e bens e aos filhos ou outros descendentes; na falta destes, aos pais ou outros ascendentes; e, por último aos irmãos ou sobrinhos que os representem. 3. O montante da indemnização será fixado equitativamente pelo tribunal, tendo em atenção, em qualquer caso, as circunstâncias referidas no artigo 494; no caso de morte, podem ser atendidos não só os danos não patrimoniais sofridos pela vítima, como os sofridos pelas pessoas com direito a indemnização nos termos número anterior. Código Civil Português, Atualizado até Dec.-Lei n. ${ }^{\circ}$ 38/2003, de 08.03.(Decreto-Lei Nº 47344, de 25 de Novembro de 1966).

97 Art. 948 II. No caso de homicídio, a indenização consiste, sem excluir outras reparações: - na prestação de alimentos às pessoas a quem o morto os devia, levando-se em conta a duração provável da vida da vítima. ( BRASIL. Lei N ${ }^{\circ}$ 10.406, Código Civil do Brasil, de 10 de janeiro de 2002)

${ }^{98}$ Em se tratando de morto ou de ausente, são partes legítimas para requerer essa proteção o cônjuge, os ascendentes ou os descendentes. BRASIL. Lei № 10.406, Código Civil do Brasil de 10 de janeiro de 2002, art.20, parágrafo único. 
3.

No relativo ás pessoas obrigadas a ressarcir o dano, a regra é que cada qual repare os danos dos que é responsável, não obstante, o Código Civil brasileiro contém numerosas hipóteses, onde a obrigação também recai em uma pessoa pelos fatos danosos de outros (BITTAR, 1994, p. 137), com os quais, existe um vínculo jurídico, por exemplo, o dos pais ou tutores com seus filhos ou tutelados que sejam menores de idade ou incapazes legalmente, devido ao dever de guarda, vigilância e custódia que estas pessoas têm ${ }^{99}$. Estas são hipóteses de responsabilidade objetiva, ao igual que os danos provenientes do fato de animais, pela ruina de um edifício e por coisas caídas do prédio ${ }^{100}$.

Com relação aos danos pelos que responde o Estado, deriva-se da sua própria obrigação para com os cidadãos, e também do exercício extra limitado de seu poder. Pode evidenciar-se por qualquer medida que podia haver tomado para evitar o dano acontecido, e que não adotou embora se encontrasse no âmbito de sua obrigação. Também responde o Estado e seus funcionários pelas prisões indevidas, condenações criminais injustas, perseguições injustas; de restrições à liberdade; de tortura e de lesões ou de morte em deficiências do sistema carcerário e da rede pública de atendimento hospitalar, entre outras ações em que o dano

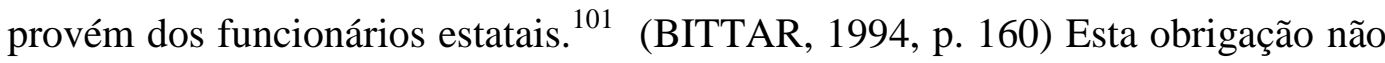
depende da culpa, analisa-se sob a previsão da responsabilidade objetiva fundada na teoria do risco administrativo. (CAVALIERI FILHO, 2004, p. 235 e 259)

Esta situação deriva-se da própria noção do dano moral e da prova exigida por parte do órgão judicial, ao assemelhar de forma errônea o dano moral com dor e sofrimento. Com esta posição, poder-se-ia interpretar que quando acontece a morte de uma pessoa estariam legitimados para acionar, todos aqueles que experimentaram e exteriorizaram os sentimentos aos que faz alusão o tribunal para conceder a reparação ${ }^{102}$. De ser assim, resulta, arbitrária aquela normativa que limita a ação para alguns parentes, toda vez, que podem existir amigos, pessoas

\footnotetext{
${ }^{99}$ Ver artigo 932 do Código Civil brasileiro.

${ }^{100}$ Ver artigos 936-938 do Código Civil vigente.

101 (..) atuação policial; de atos judiciais danosos; de desapropriação; de embargo indevido de obra licenciada; de extravio de verba em depositário público etc. Sob o aspecto político, ingerências indevidas na vida privada; imposições constantes de leis injustas; campanhas de desacredito; restrições de direitos políticos ou eleitorais; cerceamento ao exercício de direitos etc. Sob o prisma profissional, obstáculos a acesso a concurso ou a cargo; sanciones indevidas; imposição de tributos não devidos ou resultantes de normas ilegais ou inconstitucionais. No âmbito negocial, inadimplemento de obrigações contratuais assumidas; mora no atendimento de obrigações; práticas de atos contrários ao avençado. (BITTAR, 1994, p. 161).

${ }^{102}$ Ver no Item 3.2.
} 
3.

conhecidas que experimentem essa dor ao igual que a família do causante. (BODIN DE MORAES, 2003, p. 44)

\section{5. \\ Apreciação dos Critérios adotados pelos juízes brasileiros para a quantificação do Dano Moral.}

Em alusão à liquidação do dano moral no Brasil, pode-se afirmar que se para o dano patrimonial permanece válida a expressão das perdas e danos ${ }^{103}$; com relação ao dano moral a liquidação fica exclusivamente restringida ao arbítrio do juiz, não se percebendo na lei civil nenhum pressuposto ou tarifa pré-fixada pelo legislador que, de certa forma, possa constituir uma guia para a consecutiva aferição de valor do dano em questão (BODIN DE MORAES, 2003, p. 161-162) evitando a possível discricionariedade injustificada por parte do juiz. (BRASIL. Lei $\mathrm{N}^{\circ} 10.406$, de 10 de janeiro de 2002, art. 403; 944 e 952).

O sistema judicial ostenta amplos poderes concedidos de forma explicita pelo legislador brasileiro. (BRASIL, Código de Processo Civil, Lei No 13.105 , de 16 de março de 2015, art. 139-143). Precisamente no amplo poder para estabelecer o quantum indenizatório, radica uma das principais dificuldades visada por parte da doutrina, pois não existem parâmetros legais ou normas que disciplinem esta função judicial. Desta forma, o juiz exerce o papel de jusrisprudência e também figura como órgão legislativo do país, já que, cria parâmetros que não estão uniformes, o que traz como resultado decisões contraditórias e diferentes ante casos similares. Os critérios adotados são: a condição pessoal da vítima; a condição do ofensor; a extensão do dano e as condições nas quais ele se realizou. (MULHOLLAND, 2010, p. 34)

Ao contrário, outros juristas são fies defensores da tarefa judicial, argumentam que o tribunal através do seu livre arbítrio pode perfeitamente delimitar o monte indenizatório, ressaltando, ainda mais o papel preponderante do juiz na defesa dos valores concernentes ao indivíduo. (BITTAR, 1994, p. 207208). No art. 953 do Código Civil, especificamente o parágrafo único, o legislador deposita no juiz ampla liberdade à hora de adotar o monte indenizatório: "Se o

${ }^{103}$ Ver art. 402 (BRASIL. Lei $N^{\circ} 10.406$, de 10 de janeiro de 2002). 
3.

ofendido não puder provar prejuízo material, caberá ao juiz fixar, eqüitativamente, o valor da indenização, na conformidade das circunstâncias do caso".

O juiz na delimitação da quantia a pagar adota parâmetros por analogia, tomando em consideração artigos de outras leis, já revogados, como é o caso do artigo 84 do Código brasileiro de Telecomunicações de 1962, o qual expõe como critérios: a posição social ou política do ofendido, situação econômica do ofensor, intensidade do ânimo de ofender, gravidade e repercussão da ofensa, e, determina que a soma da reparação seja de 5 até 100 vezes o maior salário-mínimo vigente no país; concedendo a possibilidade que o valor da indenização será elevado ao dobro quando se comprova a reincidência do ofensor em ilícito contra a honra. $\mathrm{O}$ problema radica em que este artigo foi revogado pelo Decreto- Lei 236 de 28 de fevereiro de 1967 , lei complementar e modificadora da primeira ${ }^{104}$ particular que não incide de forma alguma para sua consecutiva utilização pelo tribunal.

As condições econômicas das partes e o grau de culpa do ofensor não devem ser considerados como parâmetros delimitadores da quantia a pagar, pois, através de sua valoração se permite a interposição de um valor adicional ao que inicialmente será concedido em virtude da reparação, estes critérios propiciam a aplicação do caráter punitivo (BODIN DE MORAES, 2003, p. 31-32,276). A partir desta percepção, sempre que o lesante agir com dolo, ele vai ser punido pelo tribunal sem sequer valorar a magnitude do dano causado. (MONTEIRO FILHO, 2000, p. 146-147); questão que resulta criticável, toda vez que, nem sempre a maior culpa deve-se conceder maior reparação monetária, corresponde analisar-se o dano ${ }^{105}$, pois, pode ser que condutas não intencionais gerem danos de maior envergadura do que possa derivar-se de uma conduta culposa.

De igual forma, as condições econômicas das partes não devem ser valoradas; uma maior riqueza do agente não justifica a imposição de uma quantia maior a pagar; e no caso de que o ofensor não ostente meios econômicos suficientes não seria uma exceção a seu dever de indenizar, devendo assumir outras tarefas em favor do lesado. Igual acontece no caso da vítima, não porque

\footnotetext{
${ }^{104}$ Ver art. 84 do Código brasileiro de Telecomunicações Lei 4.117 de 27 de agosto de 1962, modificado e revogado pelo Decreto-Lei 236 de 28 de fevereiro de 1967.

Ver Carlos. Nelson. KONDER, Critérios para a reparação do dano moral. Direito, estado e Sociedade, Departamento de Direito da PUC-Rio, n.18, jan. /jul., 2001, p.47 e ss.) In: (BODIN DE MORAES, 2003, p. 295-296)

${ }^{105}$ Art. 944. A indenização mede-se pela extensão do dano. Parágrafo único. Se houver excessiva desproporção entre a gravidade da culpa e o dano, poderá o juiz reduzir, eqüitativamente, a indenização. Lei nº 10.406, de 10de janeiro de 2002, Código Civil.
} 
3.

essa pessoa tenha maior aquisição econômica deve receber uma soma monetária maior, se essa fosse a interpretação, estar-se-ia enriquecendo injustificadamente, dando-se mais aos que têm mais, e menos aos que não estão na mesma posição.

Deve-se lembrar de que a reparação do dano moral tem caráter compensatório, não se justificando sob sua dinâmica o enriquecimento de uma pessoa em detrimento do empobrecimento de outra (CAVALIERI FILHO, 2004, p. 107) simplesmente o que corresponde é que o lesado de forma injusta seja recompensado, sendo válidos todos os mecanismos destinados a esse fim. ${ }^{106}$

Outra questão se refere à adoção da perda da chance no quantum indenizatório, a que também é abraçada pelo órgão judicial indenizando tudo o que a vítima poderia ter lucrado no caso de que o dano não tivesse acontecido; ou prevendo a indenização do que se poderia ter evitado no caso de que o causador do dano tivesse agido, ou não, ante determinada situação. (MULHOLLAND, 2010, p. 35). Ou seja, seria o ressarcimento pela oportunidade perdida. Desta forma, são ressarcidas todas aquelas oportunidades sem se verificar se elas são certas. Não corresponde reparar danos possíveis, senão verificar que sejam certos, só desta forma a perda da chance pode ser justificada. Tanto a ampliação das hipóteses de danos reparáveis; quanto a adoção de um caráter punitivo na quantificação dos danos morais; e a tutela indenizatória da perda da chance são as três problemáticas que existem, em relação à concepção, delimitação e reparação do dano moral. (MULHOLLAND, 2010, p. 25)

Por outra parte, o juiz, na sua complexa tarefa de fixar a quantia a pagar não adota propriamente normas legais, sobretudo constitucionais, assim como outras leis que possam ser aplicadas de forma análoga e que permitam conceder uma motivação da sentença lógica, racional e justa para ambos litigantes. (BODIN DE MORAES, 2003, p. 280) Certamente não existe outro meio mais adequado para fixar o dano moral a não ser pelo arbitramento judicial, mas não pode se afastar dos princípios da proporcionalidade, justiça e da razoabilidade, hoje tidos como princípios constitucionais. (CAVALIERI FILHO, 2004, p. 106 e 109) Outra questão é relativa ao caráter punitivo adotado pelos tribunais brasileiros na determinação do quantum indenizatório, o qual será analissado no consecutivo.

\footnotetext{
${ }^{106}$ Art. 403. Ainda que a inexecução resulte de dolo do devedor, as perdas e danos só incluem os prejuízos efetivos e os lucros cessantes por efeito dela direto e imediato, sem prejuízo do disposto na lei processual. Lei no 10.406 , de 10de janeiro de 2002, Código Civil.
} 
3.

\subsection{1.}

\section{Dano Punitivo}

A origem do dano puntivo encontra-se inserida no sistema anglo-saxão e se traduz como uma pena econômica superior que deve abonar o lesante a favor do lesado. Nos ordenamentos regidos pelo sistema romano-germânica, esta figura não se apresenta como nos países pertenecentes à Common Law; já que, nos primeiros nega-se a sua função no processo civil, conferida somente ao processo penal. No ordenamento jurídico brasileiro não se encontra tipificado legalmente, porém, o órgão judicial o tem adotado para castigar condutas que vulneram o padrão social estabelecido. (BODIN DE MORAES, 2003, p. 228-257)

No Brasil, o instituto foi instaurado como uma figura atípica e intermédia entre direito civil e penal, ao ser punido o lesante mediante o pagamento de uma quantia à vítima. ${ }^{107}$, tentando desta forma, mudar-se a concepção da responsabilidade civil que não se veria esgotada na reparação da vítima, senão que, seriam adicionadas funções de punição, castigo, prevenção e dissuasão, destinadas ao lesante e à própria coletividade. O caráter punitivo está inserido como método seguro para evitar a prática de novas condutas ilícitas e ações antissociais, penalizando a quem provocou o dano, dispondo um valor superior à indenização solicitada e infringindo a equivalência que deve existir entre o dano e sua correspondente reparação. (BODIN DE MORAES, 2003, p. 28-29)

Esta situação alcança critérios diferentes entre os autores da doutrina brasileira, considerando-se por alguns tão prejudicial ao ponto de incorrer nos preceitos 884 e seguintes do Código Civil, referidos ao Enriquecimento sem Causa $^{108}$. De forma contrária, alguns justificam sua prática, quando ficam demonstrados os elementos da responsabilidade civil, proporcionando compensação ao ofendido e punição ao infrator. (MONTEIRO FILHO, 2000, p. 152). De acordo com a magnitude do dolo será a sanção correspondente, ou seja, quanto maior dolo maior sanção, dispensando-se neste caso a punição que vai

107 Ver: Antonino. PROCIDA MIRABELLI DI LAURO, La riparazione dei danni alla persona,p. 123 e ss. De igual forma explicam a nova função da responsabilidade civil em relação ao caráter punitivo: Geneviève. VINEY; B. MARKESINIS, La réparation du dommage corporel, p.59 e A. PROCIDA MIRABELLI DI LAURO, La riparazione dei danni alla persona,p. 137 In: (BODIN DE MORAES, 2003, p. 258).

${ }^{108}$ Ver arts. 884 e ss. (BRASIL. Lei No 10.406 , de 10 de janeiro de 2002). 
3.

servir de desestímulo a repetições danosas, cumprindo, por sua vez, uma função pedagógica para a sociedade. (MONTEIRO FILHO, 2000, p. 155-156) Há quem, na própria noção dos direitos da personalidade entende que a vítima que é lesionada nesses direitos está facultada para obter a medida cautelar ou punitiva contra o causador do dano. (DA SILVA PEREIRA, 2016, p. 204)

Através da condição econômica do agressor adota-se este elemento, naquele caso em que ostente muitos recursos, a quantia designada pelo tribunal deve ser maior, com o fim de impor uma condenação suficientemente capaz de evitar o exercício de novas codutas infratoras; função que só será alcançada através do dano punitivo, uma vez que, aquele autor com grandes recursos não experimentará diminuição alguma no seu patrimônio. (MONTEIRO FILHO, 2000, p. 155-156). O dano punitivo tem sido criticado por Diez-Picazo:

(...) hay que sostener que la figura de los daños punitivos es ajena a los ordenamientos de corte europeo continental y que hay poderosas razones para eso. Si se quiere castigar y se está autorizado para castigar, no parece justo ni equitativo proporcionar a quien sufrió un daño sumas que sean superiores a este daño, porque en tal caso se le está enriqueciendo. ${ }^{109}$

Contrariamente, justifica-se sua existência através da Teoria da Sanção, a que procura não deixar impune ao causador do fato ilícito injusto. Justificando-se a reparação do dano moral através da consideração do agente lesante em alusão ao imperativo de que "no ódio ao delito se castigue ao delinquente pela sua ação injusta", não constituindo, deste modo, um ressarcimento senão uma pena civil que reprova exemplarmente o fato cometido pelo ofensor. Sustentando, parte da doutrina estrangeira que quando se trata de reparação por danos morais a indenização não tem caráter ressarcitório, senão punitivo. (LLAMBIAS, BENEGAS RAFFO e SASSOT, 1997, p. 104 e 111)

No caso do Brasil, percebe-se a adoção deste elemento de forma arbitrária pelos juízes, toda vez que, da interpretação que se faz do artigo 944 do Código Civil pode-se deduzir a sua proibição. A mencionada norma propicia a faculdade do juiz de diminuir o monte indenizatório e não de aumentá-lo, e no caso do dano punitivo sempre se vai falar de valor adicional. (BODIN DE MORAES, 2003, p.

109 Trad.: (...) há que sustentar que a figura dos danos punitivos é alheia aos ordenamentos de corte europeu continental e que há poderosas razões para isso. Si se quer castigar e se está autorizado para castigar, não parece justo nem equitativo proporcionar a quem sofreu um dano somas que sejam superiores a este dano, porque em tal caso se lhe está enriquecendo. (DÍEZ PICAZO, 1999, p. 46) 
3.

227) (MULHOLLAND, 2010, p. 55) Interpretação contrária desta própria norma foi expressa no enunciado n. 379, aprovado na IV Jornada de Direito Civil que disse: "O art. 944, do Código Civil não afasta a possibilidade de se reconhecer a função punitiva ou pedagógica da responsabilidade civil" ${ }^{110}$.

Juristas contrários à adoção do caráter punitivo entendem que, para que este seja adotado precisa-se uma norma legal que o justifique ou de um delito, uma vez que nulla poena sine lege; nullum crimen sine lege. (MELO DA SILVA, 1999, p. 573) A própria diferenciação entre o direito civil e o penal pode delimitar a qual das duas ramas pertence a figura do dano punitivo. Para a configuração do dano moral só se precisa um ato injusto que vulnere o princípio neminem laedere, e o dano provocado tem que ser certo; ao contrário do delito que também reconhece a responsabilidade do réu embora não se consume a ação delitiva. O principal expoente da responsabilidade civil é a vítima, não o ofensor, mede-se a extensão do prejuízo para a graduação do quantum reparador e não a culpa do autor. A pena não passa jamais do delinquente; porém, na reparação do dano transmite-se o ônus aos herdeiros do ofensor. ${ }^{111}$ No caso do crime a regra é a punição, a medida que a culpa é maior então maior é a condena; ao contrário na via civil, a indenização será proporcional ao dano sofrido pelo lesado. (CAVALIERI FILHO, 2004, p. 49)

Outros autores vêm na utilização do dano punitivo a forma de reprimir a conduta lesante, através da fixação de valor que serve como desestímulo a novas agressões coerente com o espírito dos referidos punitive ou exemplary damages da tradição anglo-saxã, traduzido na advertência do lesante e da sociedade de que não se aceita esse comportamento. Deve, pois, ser quantia significativa, em razão das potencialidades do patrimônio do lesante. (BITTAR, 1994, p. 112 e 120)

Os que rejeitam a aplicação deste dano, ao menos da forma em que se exerce pelos tribunais brasileiros; percebem a impossibilidade da fixação equilibrada e moderada do quantum indenizatório, justamente, pela presença do dano punitivo adicionada ao arbítrio concedido aos juízes. Observando na aplicação desta figura, um chamado à infração da boa-fé, e a mercantilização das relações existenciais inerentes ao ser humano. (BODIN DE MORAES, 2003, p. 261) Justifica-se sua aplicação nos casos preestabelecidos em lei ou ante situações

\footnotetext{
${ }^{110}$ Ver IV Jornada de Direito Civil, org. Ministro Ruy Rosadi de Aguiar Jr. Brasília: Conselho da Justiça Federal, 2007. 2 v., In: (DE ANDRADE LEVY, 2012, p. 71)

${ }^{111}$ Ver René Savatier, Traité de la Responsabilité Civile en Droit Français, Paris, 2. Vol. n. 632). In: (MELO DA SILVA, 1999, p. 573)
} 
3. Tratamento e aplicação do Dano Moral no Ordenamento Jurídico Brasileiro.

excepcionais, sobretudo, quando o bem atingido pertence a toda a sociedade, exemplo, os danos ao Meio Ambiente (BODIN DE MORAES, 2003, p. 263-264).

O certo é que a doutrina brasileira no seu compromisso incessante de procurar a forma mais abarcadora da responsabilidade civil tem incidido consideravelmente na sua evolução. Há quem fala de um Direito das Condutas Lesivas, materializado precisamente nos punitive damages, (DE ANDRADE LEVY, 2012, p. 33) como via eficaz para adotar-se uma compensação mais abarcadora do dano moral, que não só consideraria à vítima senão que se encaminharia a desestimular ao lesante. (DE ANDRADE LEVY, 2012, p. 67)

$\mathrm{O}$ autor citado, demanda a exigência do caráter punitivo naqueles danos que se bem não têm grande repercussão para um só individuo pode trazer um prejuízo social suscetível de amparo. Tal é o caso dos limbos jurídicos das microlessões (DE ANDRADE LEVY, 2012, p. 103), situações nas que se demanda um atuar coletivo, já que, a probabilidade de que se concedam indenizações individuais é escassa, devido ao diminuto valor econômico que teriam as mesmas, trazendo como resultado tanto a irreparabilidade da vítima como a não responsabilização do agente. (DE ANDRADE LEVY, 2012, p. 104 e 124)

Além disso, apresenta-se a possibilidade da socialização dos riscos e a multiplicação dos mecanismos extrajudiciais de indenização, entendendo não só a reparação da vítima, como também a correspondente punição do ofensor. (DE ANDRADE LEVY, 2012, p. 163). Através de mecanismos, tais como os seguros, pretende-se variar o papel da responsabilidade civil, constituindo-se um verdadeiro direito de danos. (DE ANDRADE LEVY, 2012, p. 221-222, 226)

Ao contrário outros autores percebem a solução do problema nos próprios elementos da responsabilidade civil, devendo-se reconsiderar pelo juiz a importância da culpa ${ }^{112}$; já que, mediante a valoração deste elemento, pode permitir-se a redução em consideração do patrimônio mínimo do ofensor, servindo para considerar a verba que deve ser destinada à vítima do dano. (MULHOLLAND, 2010, p. 56). Do mesmo modo, o exame do nexo de causalidade é imprescindível e tem dupla função, já que, não só se utiliza para determinar a relação entre a conduta do agente e o dano ocasionado; senão que também é perfeitamente utilizado para identificar o responsável que está obrigado

${ }^{112}$ Ver item 3.4. 
3.

a reparar esse detrimento, resultando assim, ser um limitador do quantum indenizatório (MULHOLLAND, 2010, p. 57). Em dependência da conduta assumida e do resultado provocado no direito existencial do lesado, assim será a quantia econômica à que se encontra sujeito o lesante; sempre através da efetiva demonstração da relação indissolúvel da causa-efeito. Neste sentido, a culpa e o nexo causal serão a guia do juiz, na hora de definir o quantia a pagar, levando em consideração a conduta do lesante e também os efeitos do dano cometido.

Como elemento positivo, vários autores da doutrina brasileira vêm solicitando a reparação da forma mais completa possível, não só adotando o aspecto econômico senão também outras vias inseridas no ordenamento jurídico brasileiro, as que podem ser aplicáveis, de forma análoga, pela própria dinâmica do sistema e em alusão a sua interação vinculada aos fundamentos do Estado. O direito de resposta regulado na Lei 13.188 de 11 de novembro de $2015^{113}$ pode ser adotado na reparação do dano moral, assim como a forma de retificar o fato constrangedor, tal e como o estipula a Lei 5.988 de $1973,{ }^{114}$ também pode ser acolhida a Lei 8.078 de 1990 sobre a proteção do consumidor ${ }^{115}$. (BITTAR, 1994, p. 217-219). De igual forma, após a Constituição e sua ampla proteção e consagração do dano moral, enaltecendo a obrigatoriedade da sua reparação, mediante o artigo 5 incisos $\mathrm{V}$ e $\mathrm{X}$ pode perfeitamente abarcar-se outras vias idôneas que não se traduzem somente em dinheiro. Estas medidas compensam o dano moral sofrido pela vítima. (SCHREIBER, 2011, p. 79)

\footnotetext{
${ }^{113}$ Regula o exercício do direito de resposta ou retificação do ofendido em matéria divulgada, publicada ou transmitida por veículo de comunicação social. Dispõe além da retratação ou retificação espontânea, o exercício do direito de resposta pelo ofendido e a reparação por dano moral. (BRASIL. Lei $\mathrm{N}^{\mathrm{o}}$ 13.188, de 11 de novembro de 2015, art. 1 e $2 \S 3^{\mathrm{o}}$ ).

114 Art.126 Quem na utilização por qualquer meio ou processo, de obra intelectual, deixar de indicar ou de anunciar, como tal, o nome, pseudônimo ou sinal convencional do autor, intérprete ou executante, além de responder por danos morais, está obrigado a divulgar lhe a identidade. Lei 5.988 de 14 de dezembro de 1973. Revogada pela Lei 9.610 de 1998, arts. 24 e 108.

${ }^{115} \mathrm{O}$ artigo 78, segundo o disposto nos arts. 44-47 do Decreto-Lei n⿳0 2.848, de 7 de dezembro de 1940, Código Penal, modificados pela Lei 9.714 de 25 de novembro de 1998, concede a possibilidade de aplicar outras medidas além das penas privativas de liberdade e de multa, como são: a interdição temporária de direitos; pagamento em dinheiro à vítima, a seus dependentes ou a entidade pública ou privada com destinação social, de importância fixada pelo juiz, se houver aceitação do beneficiário, a prestação pecuniária pode consistir em prestação de outra natureza; a prestação de serviços à comunidade ou a entidades públicas. Por outra parte o artigo 44 expõe que: os órgãos públicos de defesa do consumidor manterão em cadastros atualizados as reclamações fundamentadas contra fornecedores de produtos e serviços, devendo divulgá-lo pública e anualmente. A divulgação indicará se a reclamação foi atendida ou não pelo fornecedor. Lei 8.078 de 11 de setembro de 1990, Código de Defesa do Consumidor.
} 
3.

Resulta também aceitável, em termos de reparabilidade, a função que podem desempenhar os seguros e a instituição da seguridade social, como vias eficazes para a solidarização na reparação dos danos extrapatrimoniais. Tal e como vem acontecendo com o dano decorrente de acidente de trabalho ${ }^{116}$, garantida sua reparação por meio de um seguro coletivo a cargo do empregado. De igual forma, acontece no seguro decorrente de acidentes de veículos ${ }^{117}$, modificado pela Lei 8.441 de 13 de julho de 1992 que propiciou a indenização mais abrangente dos danos pessoais causados por veículos automotores de via terrestre. (CAVALIERI FILHO, 2004, p. 151) O papel do seguro constitui uma garantia para as partes do litígio, já que, permite que a vítima seja indenizada imediatamente, assim como uma maior previsibilidade de custos dos acidentes para o ofensor ${ }^{118}$.

Quantificar o dano moral, não deveria ser uma obrigação imposta para todos os litígios. Devem ser consideradas outras formas pelas quais, o magistrado possa aplicar justiça atingindo a finalidade da responsabilidade civil, além da reparação pecuniária. (BITTAR, 1994, p. 217-218) Porém o que deve-se determinar de forma adequada é a existência de um dano injusto que transgrida a dignidade humana, tentando-se realizar uma valoração detalhada do nexo causal, a fim de determinar que o prejuízo criado deriva-se da conduta do ofensor transgressor do dever jurídico pré-instiuído. A partir desta análise corresponde então a reparação do dano extrapatrimonial, destinando-se todas as vias possíveis, tanto a reparação pecuniária, retratação do ofensor, resposta proporcional do dano, assim como a participação ativa do Estado e suas instuições podendo reger o sistema de seguros e a seguridade social como mecanismos propícios a tais efetos.

\section{6.}

\section{Valoração das Resoluções emitidas pelo Tribunal de Justiça do Estado de Rio de Janeiro no primeiro semestre do ano 2017.}

No caso do Brasil, foi possível realizar uma pesquisa digital das resoluções emitidas pelo Tribunal de Justiça do Estado de Rio de Janeiro (TJRJ) nos casos de

\footnotetext{
${ }^{116}$ Ver neste sentido: art. 7, inciso XXVIII da Constituição em adição à Lei 8.213 de 24 de julho de 1991 regulamentada pelo Decreto 2.172 de 5 de março de 1997.

${ }^{117}$ Ver lei 6.194 de 19 de dezembro de 1974 modificada pela Lei 8.441 de 13 de julho de 1992

${ }^{118}$ Viney e Jourdain. Les effs de la responsabilité, p.635. In: (DE ANDRADE LEVY, 2012, p. 187)
} 
3.

responsabilidade civil por dano moral. A diferença do que acontece em $\mathrm{Cuba}^{119}$, foi possível o acesso a uma página digital onde estão disponibilizadas as decisões adotadas por este tribunal em matéria de responsabilidade civil, o que facilitou seu estudo para sustentar a fundamentação teórica precedente. Inicialmente concebeuse a ideia de realizar a pesquisa tomando em consideração os assuntos resolvidos no ano 2016, mas, devido à imensa quantidade encontrada ${ }^{120}$ decidiu-se examinar só o ementário do primeiro semestre do ano 2017 (janeiro a julho), encontrando-se 138 decisões ${ }^{121}$, cifra qualitativamente adequada para os fins desta dissertação.

Das 138 decisões pesquisadas, 17 não reconhecem a existência de dano moral; 2 decisões tratam sobre a inclusão de enunciados na súmula de jurisprudência as quais incluem os seguintes enunciados: "O Abuso de direito de demandar gera direito à indenização" e "Para a configuração da responsabilidade por danos morais à pessoa jurídica é imprescindível que a conduta do agente viole sua honra objetiva"; ficando configurado o dano moral nas 119 decisões restantes. Na seguinte figura apresenta-se a quantidade de casos analisados e sua repartição.

\section{Quantidades de Casos Apresentados}

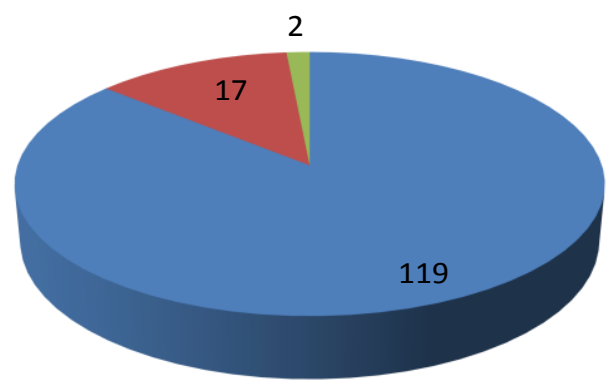

- Consideram dano moral.

- Não consideram dano moral.

- Inclusão de enunciados na súmula de jurisprudência.

Figura 1 - Casos Apresentados.

\footnotetext{
${ }^{119}$ Ver item 2.7.

120 No ano 2016 até 2017 foram encontradas 62435 decisões Consultado: http://www4.tiji.jus.br/EJURIS/ProcessarConsJuris.aspx?PageSeq=0 Acesso em 25 de agosto de 2017. Considerando essa própria informação, foi realizado o mesmo procedimento com relação ao ano 2017 e ainda assim se encontraram 24765 decisões Consultado em: http://www4.tjri.jus.br/EJURIS/ProcessarConsJuris.aspx?PageSeq=1 Acesso em 25 de agosto de 2017. Estes números evidenciam que certamente está acontecendo uma proliferação das demandas apresentadas, dando lugar ao crescimento da indústria do dano moral no país.

${ }_{121}$ Consultado em: http://www4.tjri.jus.br/EJURIS/ProcessarConsJuris.aspx?PageSeq=1. Acesso em 25 de agosto de 2017.
} 
3.

Das 119 decisões que reconhecem a configuração de danos morais, quase todas estão fundamentadas pela Lei $\mathrm{n}^{\circ}$ 8.078, de 11 de setembro de1990, Código de Defesa do Consumidor (CDC), especificamente nos artigos $2^{\circ}$ e $3^{\circ}$ referentes às partes da relação consumerista; o $6^{\circ}$ atinente aos direitos do consumidor dando ênfase ao direito de informação; do $14^{\circ}-25^{\circ}$ relativos às responsabilidades do fornecedor de serviços e a responsabilidade solidária quando há mais de um responsável do dano; $51^{\circ}$ e seguintes indicativos das cláusulas abusivas na contratação, etc.

De igual forma, algumas das disposições estiveram fundamentadas na Constituição Federativa do Brasil, com maior utilização do artigo 37, parágrafo $6^{\circ}$ concernente à responsabilização das pessoas jurídicas de direito público e as de direito privado prestadoras de serviços públicos. Em outros casos foram utilizados, indistintamente, o artigo $5^{\circ}$ concernente aos direitos e garantias fundamentais, em específico, assegurando a inviolabilidade da intimidade, da vida privada, da honra e da imagem das pessoas, assim como o direito de indenização pelo dano material ou moral decorrente de sua violação. Na fundamentação legal foram também usados os artigos: 236, regulador da responsabilidade civil dos notários no exercício de suas funções; o 225 que consagrou o meio ambiente ecologicamente equilibrado como direito humano fundamental; o $220 \S 1^{\circ}$, caput, relativo à manifestação do pensamento, a criação, a expressão e a informação como direitos garantidos pelo Estado brasileiro, mas, sempre em observância do disposto no art. $5^{\circ}, \mathrm{IV}, \mathrm{V}, \mathrm{X}, \mathrm{XIII}$ e XIV, a fim de não serem violadas a honra e a imagem de qualquer pessoa; mediante a aplicação do princípio da proporcionalidade e a técnica da ponderação de interesses.

Foi conhecido um só caso com alusão à responsabilidade recorrente do dano moral no Marco Civil na Internet regulado na Lei 12.965 de 2014, questão relativamente nova encaminhada à proteção, sobretudo, da privacidade a honra nos meios sociais. A Lei 10.406 de 2002, Código Civil do Brasil (CC), justificou algumas das decisões adotadas pelo tribunal estudado usando a preceptiva dos artigos: 12, alusivo aos direitos da personalidade, e em específico seu parágrafo único que legitima em caso de morte da pessoa lesada, a seu cônjuge sobrevivente ou a qualquer parente em linha reta ou colateral até o quarto grau para reclamar pelas perdas e danos de que padeceu o finado; o 275 referente à solidariedade 
3. Tratamento e aplicação do Dano Moral no Ordenamento Jurídico Brasileiro.

passiva; os artigos 421 e 422 reguladores do contrato e da boa-fé objetiva na sua concertação; o 884 relativo ao enriquecimento sem causa e a obrigatoriedade de restituir o indevidamente auferido; o 186 em relação com o artigo 927 concernentes ao ato ilícito e a obrigatoriedade da reparação por dano moral; a responsabilidade do condomínio por atos de seus prepostos, regulada nos artigos 932, III e 933; o 944 concernente à indenização e sua aferição em correspondência com extensão do dano; o 948 que no caso de homicídio, abrange a reparação do dano causado através do pagamento das despesas do funeral e o luto da família e a prestação de alimentos às pessoas a quem o morto os devia, levando-se em conta a duração provável da vida da vítima; o 950, regulador da pensão vitalícia e o 953 regulador do dever de reparar o dano que resulte da injúria, difamação ou calúnia.

A Lei 5.869 de 1973, Código de Processo Civil (CPC), embora já revogada, foi usada para fundamentar aqueles casos resolvidos em primeira instância antes da entrada em vigor do novo Código de Processo Civil de 2015, especificamente no alusivo às verbas honorárias sucumbenciais fixadas nos moldes do artigo $20, \S$ $3^{\circ}$. O novo Código do Processo civil, Lei 13.105 de 2015 (CPC) também justificou alguns dos casos resolvidos, em específico os artigos: 84 e 85 , relativos às Despesas, dos Honorários Advocatícios e das Multas; 98 e 99 referentes à gratuidade da justiça; e o artigo 373 , referente aos ônus da prova.

Uma decisão foi sustentada nos artigos $5^{\circ}$ e $6^{\circ}$ da Lei $n^{\circ}$ 9870/99 que dispõe sobre o valor total das anuidades escolares, veda a suspensão de provas escolares, a retenção de documentos escolares bem como a aplicação de quaisquer outras penalidades pedagógicas. Foi conhecido um caso em correspondência com o artigo 10 da Lei 9.656 de 1998, reguladora dos planos e seguros privados de assistência à saúde e sua relação com o artigo $2^{\circ}$ do Estatuto do Idoso, Lei 10.741 de 2003. E foi adotado o Código de Trânsito Brasileiro (CTB) Lei 9.503 de 1997, artigo $181^{\circ}$ XVII relacionado com as infrações; assim como também foi argumentado um só caso com alusão à Lei 8.245 de 1991, reguladora das locações dos imóveis urbanos e seus procedimentos, especificamente o seu artigo 22 consignativo dos deveres do locador e do locatário. Na próxima figura apresentase a relação da quantidade dos casos onde ficou configurado o dano moral e a correspondente fundamentação legal usada pelo juiz atuante. 
3.

\section{Fundamentação Legal}

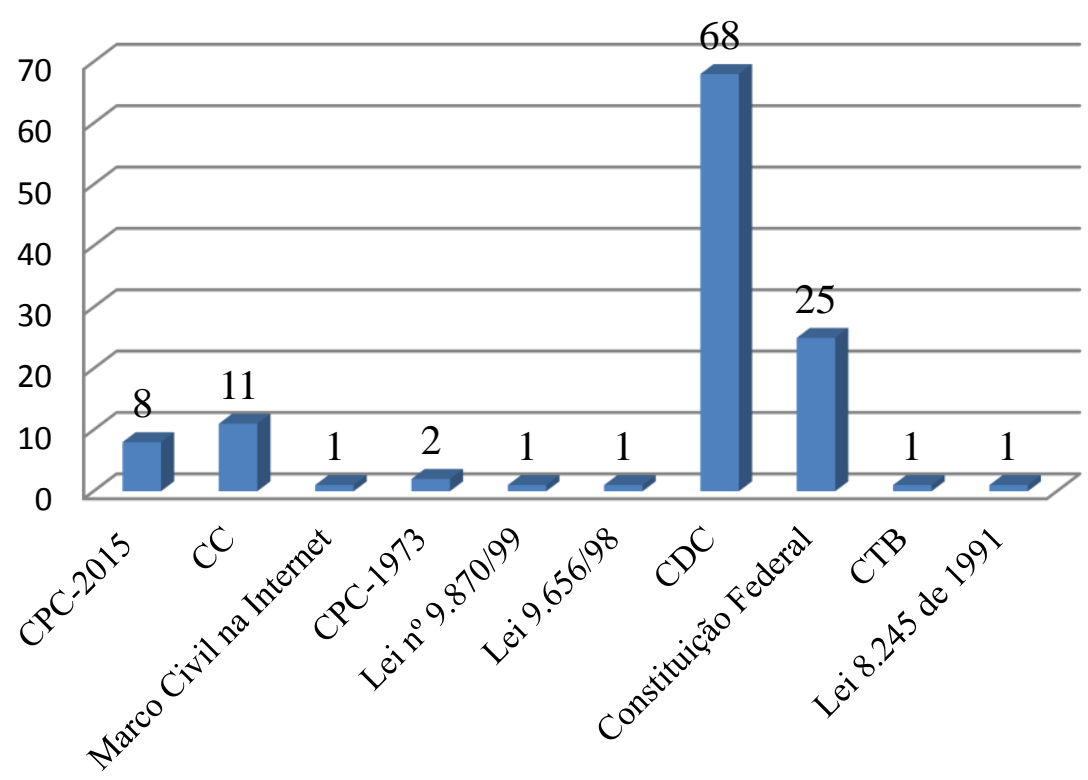

Figura 2 - Fundamentação legal.

O estudo realizado arrojou várias considerações que confirmam os aspectos sustentados nos itens precedentes, em relação ao tipo de comportamento seguido pelo poder judiciário na resolução dos casos apresentados por dano extrapatrimonial. A primeira conclusão é que quase todas as decisões foram adotadas com base na responsabilidade objetiva fundamentada na relação consumerista que tem seu maior corpo normativo no CDC. Em 23 decisões, foi entendida a responsabilidade solidária em virtude do número de causantes do dano; foram conhecidas 41 decisões onde se evidenciava o dano extrapatrimonial decorrente da responsabilidade contratual, e só em 12 casos foi configurado o dano moral baseado na responsabilidade subjetiva, analisando-se o elemento culpa para dirimir a lide. O que demostra a prática costumeira de esquecer a valoração do elemento culpa para aferir a obrigação de reparar o dano.

Num primeiro elemento diz no concernente ao próprio conceito do dano moral, o que ainda é equiparado com os seus possíveis efeitos, isso se pode evidenciar com as decisões proferidas pelos Desembargadores Relatores: Luciano Saboia Rinaldi de Carvalho, na Apelação Cível nº 0015346-61.2011.8.19.0208, Marco Antônio Ibrahim na Apelação Cível 0016392-02.2015.8.19.0061 e Murilo Kieling na Apelação Cível nº 0019851-56.2015.8.19.0208: 
3.

Quanto ao dano moral, in casu, restou caracterizado em face da angústia, ansiedade e insegurança impostas aos Autores pela recusa das Rés ao pagamento da indenização securitária ao argumento de que já a haviam pago a única herdeira.

Não há dúvidas, portanto, de que a autora, ora apelada, tenha sofrido dano moral. A dor, o sofrimento e a angústia se sobressaem de todo o episódio descrito, mostrando-se desnecessária qualquer prova dos sentimentos vivenciados pela vítima. Por toda a cadeia de acontecimentos narrada, ficou demonstrada, por si só, a situação de desgaste emocional, psicológico e físico.

O dano moral tem em seu cerne a dor íntima, o sofrimento humano, a humilhação, a vergonha; ou como diz o mestre SEVERIANO IGNÁCIO DE ARAGÃO, com a mais simples e precisa definição sobre a temática: "dano moral é a dor moral".

De igual forma, continua aplicando-se a teoria do dano in re ipsa, prevendo que só a existência de um dano, independentemente se justo ou injusto, exige reparação monetária. Esse o entendimento seguido pelas resoluções estudadas na presente pesquisa, tal e como fica considerado na Apelação Civil nº 006491688.2012.8.19.0205, emitida pelo Des- Relator. Ricardo Alberto Pereira:

(...) a teoria do dano "in re ipsa" gera presunção de que o prejuízo resulta naturalmente do ato danoso, dispensando-se prova do prejuízo concreto a indenizar. Nesse sentido entendo que "O dano moral deve ser indenizado mediante a consideração das condições pessoais do ofendido e do ofensor, da intensidade do dolo ou grau de culpa e da gravidade dos efeitos a fim de que o resultado não seja insignificante, a estimular a prática do ato ilícito, nem o enriquecimento indevido da vítima."

Em outra ordem de análise, quando se quantifica o dano moral os juízes deste tribunal fixam a soma monetária em relação a um método que nomeiam como bifásico, de acordo com o explicado na seguinte decisão da Desembargadora Relatora Andréa Fortuna na Apelação Cível no 038975651.2014.8.19.0001:

Hodiernamente, o método mais adequado para um arbitramento razoável da compensação por dano extrapatrimonial resulta da reunião dos dois critérios analisados (valorização sucessiva tanto das circunstâncias como do interesse jurídico lesado), conhecido como MÉTODO BIFÁSICO PARA O ARBITRAMENTO EQUITATIVO DA INDENIZAÇÃO. Na primeira fase, arbitra-se o valor básico ou inicial da compensação, considerando-se o interesse jurídico lesado, em conformidade com os precedentes jurisprudenciais acerca da matéria (grupo de casos). Assegura-se, com isso, uma exigência da justiça comutativa que é uma razoável igualdade de tratamento para casos semelhantes, assim como que situações distintas sejam tratadas desigualmente na medida em que se diferenciam. Na segunda fase, procede-se à fixação definitiva da compensação, ajustando-se o seu montante às peculiaridades do caso com base nas suas circunstâncias. Partindo-se, assim, da compensação básica, eleva-se ou reduz-se esse valor de acordo com as circunstâncias particulares do caso (gravidade do fato em si, culpabilidade do agente, culpa concorrente da vítima, condição econômica 
3.

das partes) até se alcançar o montante definitivo. Procede-se, assim, a um arbitramento efetivamente equitativo, que respeita as peculiaridades do caso.

Ficou corroborado o uso do dano reflexo ou ricochete, concedendo-se sempre que foi solicitado, pela simples argumentação, de que o dano conhecido gerou reflexos nas vítimas indiretas. Nos assuntos valorados sempre que se concedia dano moral à vítima, quando se solicitava dano reflexo, de igual forma era outorgado. As decisões que adotaram este tipo de dano não justificavam propriamente o dano provocado, simplesmente quando se configurava uma dor ou um constrangimento era considerado o dano reflexo para quem o solicitava. Uma das decisões que adotou este tipo de dano foi emitida pela Desembargadora Relatora Marianna Fux, na Apelação Cível nº 0333107-08.2010.8.19.0001:

No que se refere à pretensão veiculada pelo $2^{\circ}$ e $3^{\circ}$ autores, observo que se trata de pedido de indenização por danos morais ajuizado pelo companheiro e filho da vítima. Trata-se do denominado dano reflexo ou em ricochete, considerando que, embora o ato tenha sido praticado diretamente contra determinada pessoa, no caso, seus efeitos acabaram atingindo terceiros indiretamente.

Em alguns dos casos estudados, apesar de derivar-se da configuração de contrato oneroso, o juiz atuante dava provimento ao dano moral obviando o dano material claramente demonstrado, não obstante conferia proteção à situação de desagrado conferida à vítima, baixo o nome de "quebra da expectativa", como se pode apreciar na sucessiva valoração do Desembargador Relator Arthur Narciso de Oliveira Neto na Apelação Cível nº: 0054172-56.2015.8.19.0002.

Quanto ao dano moral, é certo que a quebra da expectativa do Requerente, que celebrou contrato para aquisição de imóvel e descobriu, posteriormente, que se associou a cooperativa, tendo seu sonho da casa própria frustrado, causou ao Demandante grande dissabor, ferindo seus direitos da personalidade.

O caráter punitivo continua sendo utilizado na argumentação da sentença para aferir a quantificação por dano moral, muitas vezes majorada a quantia inicialmente oferecida em primeira instância. Abaixo é possível verificar um destes argumentos, Apelação Civil nº 00374544-63.2009.8.19.0001 pela DesRelatora. Natacha Nascimento Gomes Tostes Gonçalves de Oliveira:

(...) a indenização, mormente a título de dano moral, deve ser fixada com moderação e prudência pelo julgador. Por outro lado, não deve ser insignificante, considerando-se a hipossuficiência do consumidor e a situação econômica do ofensor, eis que não pode constituir estímulo à manutenção de práticas que agridam 
3.

e violem os direitos daqueles. A fixação do montante indenizatório a título de dano moral deve considerar o dúplice aspecto do ressarcimento, que é compensatório para o lesado e punitivo para o agente causador do dano, não podendo ser insignificante e, tampouco, fonte de enriquecimento sem causa. Há, pois, que se observar os princípios da proporcionalidade e da razoabilidade.

$\mathrm{Na}$ maioria dos assuntos que tratavam de uma relação de consumo foram sustentadas as decisões na Teoria do Risco do Empreendimento, fazendo ênfase no artigo $6^{\circ}$ do $\mathrm{CDC}$, referente ao direito de informação, entendendo-se a configuração do dano moral sempre que o fornecedor do serviço transgredia o direito antes aludido, assim o explicam as Desembargadoras Relatoras: Isabela Pessanha Chagas, Apelação Cível no 0005533-69.2010.8.19.0038 e Ana Célia Montemor Soares, Apelação Cível no 0001897-68.2013.8.19.0207:

Aplica-se à hipótese a Teoria do Risco do Empreendimento (...) segundo a qual todo aquele que se disponha a exercer alguma atividade no campo do fornecimento de bens e serviços tem o dever de responder pelos fatos e vícios resultantes do empreendimento independentemente de culpa.

Pela teoria do risco do empreendimento, todo aquele que se dispõe a exercer alguma atividade no campo do fornecimento de bens e serviços têm o dever de responder pelos fatos e vícios resultantes do empreendimento, independentemente de culpa. Portanto, o dever de obediência às normas técnicas e de segurança, cujo descumprimento gera responsabilidade, decorre do simples fato da empresa se dispor a realizar atividade de prestar serviços, ou seja, os riscos do empreendimento correm por conta do fornecedor de serviços não podendo a apelante atribuir ao consumidor.

Logo da valoração minuciosa das resoluções emitidas pelo tribunal em exame se pode estabelecer um julgamento da aplicação da figura do dano moral que distancia muito do que deveria ser aplicado, fugindo a seriedade e a demonstração do dano injusto transgressor da dignidade da pessoa humana. Na maioria dos casos estudados configura-se a presença do dano material, dado o erro dos fornecedores dos serviços no exercício de sua atividade.

A Apelação Cível $\mathrm{n}^{\mathrm{o}}$ 0003971-32.2012.8.19.0207 trata de processo estabelecido pela ingestão de biscoito fabricado pela ré. $\mathrm{O}$ caso apresenta-se pela presença de corpo estranho (excrementos e pelos de roedor) no alimento. Neste caso, restou controvertido em qual momento teria se dado a contaminação do produto, o que foi confirmado pelo Expert, mas o juiz condenou ao pagamento de dano moral sob a justificação de que não logrou a Ré êxito em comprovar que a infestação teria se dado após o processo de fabricação. Além disso, o dano não foi comprovado, toda vez que, o Perito salientou que o receituário não comprovava a 
3.

enfermidade alegada pelo autor, ou que tenha sido decorrente da ingestão do alimento. Não ficando demonstrado o dano sem o qual não se configura a responsabilidade civil, porém o juiz culminou sua decisão da seguinte maneira:

Quanto aos danos morais, em que pese não tenha ficado devidamente provado que o Autor passou mal em virtude do consumo do alimento, a simples aquisição e ingestão de produto impróprio para o consumo e potencialmente nocivo à saúde provoca sensação de repugnância, nojo, aversão e sentimentos de insegurança, vulnerabilidade, além da quebra da confiança inequivocamente depositada pelo consumidor quanto à qualidade do produto adquirido e fabricado por uma das maiores e mais conhecidas empresas do setor, dando ensejo a danos morais passíveis de indenização.

De forma similar resultou $\mathrm{o}$ acontecido na Apelação $\mathrm{n}^{\circ}$ 032908414.2013.8.19.0001, no qual os autores preparavam-se para lanchar em sua residência, a primeira autora buscou um suco de soja, dentro da validade para o consumo, notando um barulho de substância sólida nele, abrindo a parte de cima da embalagem depois de já consumirem parte do conteúdo, encontrando um corpo estranho dentro da caixa, bastante desagradável. Nesse assunto não foi possível realizar a prova pericial por diferentes motivos alheios ao juiz, não ficando claramente configurado a forma em que o corpo estranho foi inserido no suco, identificando-se o dano moral já que a parte ré não logrou demonstrar nenhuma prova que desconstituísse os fatos narrados pela parte autora, desta forma evidencia-se a desigualdade no processo. Tenha-se em consideração que além que o produto não foi consumido nos estabelecimentos da própria ré resulta difícil provar que o elemento estranho não se encontrava inicialmente dentro do conteúdo da caixa. Porém o juiz entendeu a configuração do dano moral pelo só fato de ser fornecido um produto impróprio para consumo, sem comprovar a culpa do fornecedor. Desta forma, resulta uma prática costumeira dos tribunais brasileiros a de ressarcir, independentemente da comprovação do dano:

Nesse sentido, está o precedente do STJ que, em situação semelhante, decidiu que a aquisição de produto de gênero alimentício contendo em seu interior corpo estranho e com exposição do consumidor a risco concreto de lesão à sua saúde e segurança, dá direito à compensação por dano moral, ainda que não ocorra a ingestão de seu conteúdo.

Na Apelação Civil n 0000230-22.2005.8.19.0209, descreve-se a agressão a jornalista em Night Club por um jogador da seleção brasileira de futebol na copa do mundo. Se bem é certo que neste caso o jornalista estava tirando fotos sem 
3.

autorização dos jogadores e que a agressão justamente configura um dano moral, o cerne do problema encontra-se na argumentação da sentença, tomando como critério decisivo para determinar o quantum a condição pessoal do agressor, que ao ser rico e uma celebridade então devia majorar-se a soma a pagar, além disso, os danos materiais ficaram configurados de forma clara, já que o lesante quebrou a câmera fotográfica, porém, não foram considerados pelo juiz atuante:

O dano moral é superlativo e in re ipsa pela humilhação a que foi submetida a vítima, diante de todos os circundantes (...) Torna-o superlativo o fato de ser o agressor uma celebridade - fala-se, aqui, do decantado, do festejado jogador de futebol que, por força de seus reconhecidos méritos, passou à história do futebol mundial como Ronaldo Fenômeno. Ele foi prepotente e atrabiliário, qualidade muitas vezes presentes em quem chega ao status da fama. A vítima não era célebre; por força do ofício, gravita em torno dos célebres do esporte. (...) Ora, o caráter pedagógico-punitivo não admite que a indenização cumpra apenas sua função desagravadora é necessário que ela seja fiel à sua natureza inibitória, ou seja, que represente reprimenda efetiva vale dizer, que tenha um peso considerável para o ofensor, capaz de refreá-lo de futuro. (...) Nesse passo, mostra-se mais razoável triplicá-la: R\$ 30.000,00; valor histórico, ou seja, na data do ato recorrido. Afinal, se, como dito na sentença, "réu é" — ou foi — "um dos jogadores de futebol mais famosos do mundo", é ainda, empresário bem sucedido, como notório, além de rico, também como de notoriedade. (...) Não merece prosperar o pedido de indenização por danos materiais, uma vez que não há nos autos nenhuma prova do valor requerido a este título.

Se bem em alguns casos o critério referente às condições econômicas do ofensor beneficiou ao lesado, em outros resultou em extremo injusta a reparação sob este critério. $O$ anterior se comprovou na Apelação 037730885.2010.8.19.0001, na que se evidencia uma verdadeira ofensa à imagem e á honra da vítima. Neste caso a ré utilizou a imagem do autor (policial civil) em uma operação no Morro da Providência que efetivamente ocorreu e foi noticiada pela mídia. No entanto, a referida fotografia foi usada para ilustrar a capa do livro que possuía como título "Sangue Morte e Corrupção na PM do Rio". A imagem utilizada pela editora na capa do livro se mostrou totalmente descontextualizada em relação aos fatos contidos em seu interior, que, no entanto, descrevia inúmeros crimes praticados pela Polícia Militar. Com a presença da imagem podia levar a crer que os policiais nela estampados eram os mesmos descritos na obra, gerando a falsa ideia de que os primeiros estariam envolvidos nos fatos ali narrados. O juiz reconheceu o dano moral, mas, em relação ao quantum indenizatório resolveu por reduzir a quantia proferida na primeira instância pela situação financeira da $2^{\mathrm{a}}$ ré, que não aparentava estar dotada de elevados recursos econômicos. 
3. Tratamento e aplicação do Dano Moral no Ordenamento Jurídico Brasileiro.

Na apelação $n^{\circ}$. 0001251-47.2016.8.19.0209 encontra-se outro caso passível de crítica. Nela consignam os autores terem adquirido um pacote de viagem com a primeira ré e, durante a viagem, no interior do restaurante localizado no hotel pertencente à segunda ré, teve sua bolsa e pertences furtados por um casal que estava no restaurante, fato comprovado pela filmagem do espaço; condenando-se o hotel ao pagamento dos danos morais, não assim em relação aos danos materiais, embora o que foi furtado tinha um valor econômico aferível em dinheiro. Se bem é certo que as rés tinham o dever de cuidado e que devem responder pelos danos causados nos serviços oferecidos, o dano que aqui se evidencia é completamente material, e não moral, não ficou demonstrada a lesão da dignidade humana dos lesados, senão uma diminuição no seu patrimônio de forma direta, não obstante o juiz atuante ajuizou o dano moral com base na Teoria do Risco do Empreendimento, não reconhecendo o dano material já que os autores não demonstraram a quantidade de dinheiro que portavam no interior da bolsa furtada, nem sequer foi considerado o valor da bolsa em questão.

Este entendimento foi igualmente considerado na Apelação $n^{\circ} 0018410$ 15.2015.8.19.0087, na qual a autora alegou ter tido seu aparelho de telefone celular furtado dentro do estabelecimento da ré, enquanto comprava peças de vestuário. $\mathrm{O}$ dano moral ficou configurado pelo transtorno causado à autora. Não se considerando o dano material perfeitamente comprovado pelo valor do próprio telefone furtado, não constituindo, um caso onde deve ser reconhecido o dano moral e sim o detrimento material ocasionado à autora e que tem repercussão direta no seu patrimônio.

Desta forma existem decisões nas quais se concede reparação econômica por dano moral por qualquer erro do fornecedor do serviço, sem levar em consideração o dano proferido nem a lesão à dignidade humana, assim pode-se apreciar na Apelação $\mathrm{n}^{\circ}$. 0009571-73.2013.8.19.0021, onde fica ratificada falha na prestação do serviço pelo vício de um produto oferecido pela ré (refrigerador) inadequação no produto que lhe diminuiu o valor ou sua funcionalidade. O problema encontra-se na configuração do dano, sendo neste caso material e não moral ficou demonstrado o vício do produto que diminuía seu valor, pelo qual, corresponde ser ressarcido o dano material causado ao comprador, não existindo 
3.

afetação alguma em relação a seu caráter existencial, nem se configurando nenhum dano desta natureza, pois só existe o sentimento negativo experimentado pela vítima que neste caso recebeu tutela judicial sob o instituto do dano moral:

Observando-se as circunstâncias do caso concreto, notadamente a essencialidade do refrigerador e o grande lapso temporal em que a autora se viu privada de sua utilização, conclui-se que a indenização por danos morais fixada no valor de R\$ $8.500,00$ (oito mil e quinhentos reais) revela-se compatível com os Princípios da Razoabilidade e da Proporcionalidade, bem como se aproxima dos patamares adotados por esta Corte, em casos semelhantes.

Na Apelação $n^{\circ}$ 0008335-18.2016.8.19.0042 foi concedida indenização por dano moral à autora por excesso de prazo na fila de instituição financeira durante gestação de risco com prescrição de repouso. Hipótese que, para o juiz, ultrapassou o mero descumprimento legal e provocou situação aflitiva e preocupante. Neste caso, não foi configurado um dano propriamente dito, senão que se indenizou à lesada pelo dano que poderia haver acontecido e por seu sentimento de aflição e preocupação, sendo indenizada na quantia de $\mathrm{R} \$ 3.000,00$.

Quase todas as decisões pesquisadas dispõem uma reparação monetária excessiva, vulnerando assim outras vias efetivamente válidas para que fique ressarcida a vítima do detrimento. Na apelação no 0002039-82.2016.8.19.0202, o juiz atuante poderia ter se sustentado no direito de resposta constitucionalmente estipulado como meio eficaz de reparação por dano moral, porém sua decisão foi unicamente pecuniária. Trata-se do autor acusado da prática de furto no interior de uma loja. Neste caso é acertado o dano moral proferido, toda vez que, ao lesante lhe foi atingida sua dignidade ao ser acusado de furtar uma boneca da loja na presença de vários espectadores. O cerne do problema está na forma adotada para reparar esse prejuízo, considero que a sentença poderia ter se baseado no direito de resposta ou bem a retratação pública da loja ré tal e como estabelece o artigo $5^{\circ}, \mathrm{V}$ da Constituição Federal, podendo ser utilizados os meios sociais com este fim, forma da qual fica reparada a vítima de forma eficaz, voltando a ser colocada na situação que se encontrava antes de suportar o dano suportado.

Em outra ordem de análise, dentro daqueles casos em que não foi configurado o dano moral, também se evidenciam críticas em relação aos fatos e à argumentação do juiz. Na apelação $n^{\circ}$. 0004450-25.2012.8.19.0207 descreve-se a 
3.

forma em que ficou abordada de forma injusta a dignidade humana do autor ao ser levado à policia, sofrendo agressões verbais e perseguição por parte dos demandados, dado o reconhecimento equivocado dos réus em sede policial acerca do autor de um suposto delito cometido no interior de sua residência. A sentença não deu seu visto favorável à constituição do dano moral, embora o apelante sofresse uma investigação penal injusta que incidiu negativamente na sua honra, ao contrário o juiz entendeu que não se configurou ato ilícito na atuação dos demandados, não tendo em consideração o dano proferido ao apelante.

(...) eis que os relatos trazidos em sede policial e os depoimentos dos policiais militares não evidenciaram qualquer prática abusiva por parte dos réus e dos agentes públicos envolvidos na diligência, a fim de localizar o autor do fato que invadiu o domicílio dos réus e subtraiu a gaiola com seus periquitos. Vale registrar que o reconhecimento equivocado em sede policial de suposto autor do fato, por si só, não revela qualquer dever de indenizar. É necessário que seja comprovado o dolo, culpa ou abuso de direito daqueles que apontaram pessoa diversa sobre a prática de crime.

Em alguns dos assuntos estudados só importa para o juiz um erro no exercício do réu para determinar a indenização por dano moral, sem ter em consideração que todos somos humanos suscetíveis de imperfeições e mais ainda na esfera laboral, se bem resulta certo que esta característica humana não afasta a responsabilização, caso esse erro provoque um dano na esfera alheia deve se comprovar que esse desacerto não possa ser tolerado em alusão ao próprio fato de viver em uma sociedade imperfeita, onde a tolerância deve figurar como aspecto imprescindível para lograr a convivência pacífica. Porém, quando esse dano seja o suficientemente injusto e transgressor da dignidade, essa tolerância deve ser esquecida passando a ser valorada a pessoa lesada e justificado o dever de reparar.

$\mathrm{Na}$ Apelação $\mathrm{n}^{\mathrm{o}}$ 0034326-67.2010.8.19.0054, essa tolerância devia prevalecer ao não ser comprovado o dano injusto causado na dignidade da pessoa lesada. Narra o fato de que o demandante recebeu um telegrama expedido pelo réu comunicando-lhe a premiação de seu título, incluindo os números finais de seu cartão de crédito. E posteriormente foi informado que teria havido equívoco no envio do telegrama, em virtude de falha operacional, e que deveria desconsiderar as informações nele contidas. Resulta certo que esse telegrama causou uma alegria que depois foi afastada sentindo sua expectativa frustrada, mas isso não justifica uma indenização no valor de $\mathrm{R} \$ 5.000,00$ a título da frustração causada ao lesado. 
3.

Com efeito, ainda que o comunicado não indicasse o valor da premiação, cuidavase de correspondência legitimamente emitida pela ré e que ainda informava os números finais do cartão de crédito do apelante, de modo a instalar em seu espírito a expectativa de ter sido contemplado e de que receberia a premiação em pecúnia. (...) O episódio, assim, ultrapassou o mero aborrecimento da vida de relação, causando abalo psicológico, sofrimento e frustração, configurando, pois, dano moral indenizável.

O modo em que os juízes consideram o dano moral, como aponta Anderson Schreiber ${ }^{122}$, possibilita a proliferação de numerosas demandas pedindo reparação econômica, casos poucos sérios que não respondem às exigências da figura jurídica, isto se pode apreciar na Apelação no 0018416-27.2013.8.19.0205, onde os autores alegam que efetivaram matrícula em curso de inglês e no mesmo dia pagaram material, no valor de $\mathrm{R} \$ 270,00$, com a promessa de recebê-lo em 15 dias, juntamente com uma caneta "Wizpen". Aduzem que, quando as aulas tiveram início, receberam a informação de que não teriam direito a tal caneta, anunciada em propaganda da ré, o que acarretou decepção. Embora o tribunal não reconhecesse o dano moral, tem se criado um entendimento social de que ante qualquer dano podem acessar à justiça exigindo uma reparação econômica.

Outro caso suscetível de polêmica é o extravio de bagagem, na Apelação ${ }^{\circ}$ 0095945-84.2015.8.19.0001 o juiz reconheceu a presença de danos morais e materiais, ficando o dano moral qualificado in re ipsa, sendo uma hipótese reconhecida pela jurisprudência do TJRJ, que vem consignando que o extravio de bagagem é situação que suplanta o mero aborrecimento, o Enunciado $n^{\circ} 45$ da Súmula da Jurisprudência Dominante do TJRJ assim o classifica: "É devida indenização por dano moral sofrido pelo passageiro, em decorrência do extravio de bagagem, nos casos de transporte aéreo".

Logo da valoração minuciosa das resoluções emitidas pelo tribunal em questão, pode-se estabelecer um julgamento da aplicação da figura do dano moral, cujo entendimento em sede judicial está longe do que deveria ser aplicado, fugindo da seriedade e a demonstração do dano injusto transgressor da dignidade da pessoa humana. Embora estas decisões comprovem que diferente do que ocorre em Cuba, o dano moral no Brasil goza de reconhecimento judicial, sua aferição prática não responde à figura em estudo, não se evidenciando uma correta valoração dos critérios necessários, mediante os quais permite configurar-se um

${ }^{122}$ Ver item 3.4. 
3.

dano como moral e estimar-se sua possível quantificação monetária ou outras vias pelas que é factível a reparação do lesado.

Precisa-se da comprovação do dano sem o qual não pode entrar-se a conhecer em termos de responsabilidade civil; da culpa do lesante, que em muitos casos é decisiva para determinar a obrigação de reparar, a qual pode ser tida em consideração ainda que a relação entre as partes da lide provenha de uma relação de consumo; dos riscos que, às vezes, resultam suficientes para conceder tutela legal e do nexo causal, imperioso para determinar a conduta do réu e a magnitude do dano; resultando daí a responsabilização do lesante, em dependência de sua conduta e do dano proferido. Só a partir da valoração efetiva dos elementos da responsabilidade civil, antes mencionados, pode estabelecer-se a adequada responsabilização do lesado e proferir-se uma reparação que seja capaz de minorar o dano provocado, que atingiu de forma injusta a dignidade da pessoa humana. 


\section{4. \\ Proposta Jurídica para a melhor interpretação e aplicação do dano moral em ambos os sistemas de direito.}

Uma vez analisado o tratamento concedido ao dano moral nos sistemas em estudo, importa propor algumas alternativas para a sua interpretação e aplicação adequada. Restou apurado em ambos os sistemas que o dano moral se evidencia na lesão à dignidade humana, sendo que a tutela incide sobre o dano injustamente sofrido e não ao injustamente causado, de modo que a responsabilidade civil aparece como um tipo de crédito compensatório mais do que como sanção ${ }^{123}$.

A reparação do dano extrapatrimonial pode adotar diferentes variantes. Em alguns casos, considera-se a compensação econômica como via efetiva para mitigação das consequências de um ato lesivo. Em Cuba, é possível adotar-se essa forma de reparação, desnecessária a criação de uma nova lei que a regule, pois, da própria interpretação unificada do sistema legal, justifica-se o pago pecuniário como opção legítima para diminuir as consequências do dano moral injustamente suportado; isto não conduz ao abandono da reparação não pecuniária, que em Cuba, alcança sua efetiva regulação com a retratação pública do ofensor ${ }^{124}$.

De igual forma, e de acordo com o princípio constitucional da solidariedade, o desempenho efetivo da seguridade social e do sistema de seguros implica no Estado um papel preponderante. Essas propostas têm como fim a reparação íntegra da vítima e a correta aplicação dos elementos da responsabilidade civil, mediante a interpretação análoga das leis que compõem o arcabouço jurídico de cada país, aliada às ferramentas que concede o direito comparado.

No caso do Brasil, o moralmente lesado pode vir a ser ressarcido por outras vias não pecuniárias. Embora no sistema brasileiro a compensação econômica

\footnotetext{
123 Ante um caso por dano moral não se procura o castigo do ofensor, pois, a finalidade da responsabilidade civil e do direito de danos radica na compensação da vítima, por isso, o amparo jurídico não vai se destinar àquele dano que injustamente ocasionou o lesante, senão àquele que de forma injusta sofreu o danificado. Precisamente aqui radica a funcionalidade da responsabilidade civil, a diferença de como era percebida na antiguidade, seu objetivo atual é a tutela da vítima tentando que a mesma seja reparada através de todas as vias que possibilitem sua colocação na situação em que previamente se encontrava antes de suportar o evento danoso, sendo a compensação econômica a forma de reparação mais frequentemente utilizada.

${ }^{124}$ Ver artigo 88 do Código Civil cubano.
} 
4.

Proposta Jurídica para a melhor interpretação e aplicação do dano moral em ambos os sistemas de direito.

desfrute de amparo civil e constitucional ${ }^{125}$ sendo uma via costumeira de ressarcimento judicial, pode ser aplicável a retratação pública como meio eficaz, através da interpretação extensiva do direito constitucional de resposta. Nesse sentido, precisa-se da argumentação jurídica racional do magistrado, sustentada no princípio constitucional da dignidade humana, cujo teor e espírito devem conduzir o resto das leis infraconstitucionais. Sempre que se configure um dano moral injusto provocado pela veiculação ou manifestação de uma informação infratora da dignidade humana pode-se aplicar o direito de resposta regulado no artigo $5^{\circ} \mathrm{V}^{126}$ do texto constitucional, o qual, não só incluiria o direito de defesa do lesado senão também o dever de retratação do ofensor pela sua conduta imprópria.

Justamente, na perspectiva do direito civil-constitucional regida pelo princípio e valor supremo da dignidade humana, estarão sustentadas as propostas oferecidas. Os preceitos da norma superior hierárquica podem e devem conduzir a argumentação jurídica de toda sentença judicial. Certamente não podemos negar o valor que contêm os Códigos Civis como pautadores do dano moral. No entanto, é impossível recusar a influência que a Constituição tem sobre o Direito Civil, decidindo positivamente na solução dos litígios suscitados. Em diversos casos, para conceder a solução apropriada ao pleito suscitado são suficientes as normas constitucionais; e quando se utilizem as leis civis tem que se fazer sob os comandos do texto constitucional, segundo ratifica Pietro Perlingieri:

(...) "uma coisa é ler o Código naquela óptica produtivista, outra é relê-lo à luz da opção ideológico-jurídica constitucional, na qual a produção encontra limites insuperáveis no respeito aos direitos fundamentais da pessoa humana". "O papel unificador do sistema, tanto nos seus aspectos mais tradicionalmente civilísticos quanto naqueles de relevância publicista, é desempenhado de maneira cada vez mais incisiva pelo Texto Constitucional”. (PERLINGIERI, 1997 )

É através dos princípios constitucionais que se pode alcançar, não só o reconhecimento da dignidade humana, mas também sua importância, proteção e ponderação em relação a outros direitos estabelecidos que se encontrem em oposição; o valor humano não precisa de codificação para receber tutela jurídica.

\footnotetext{
125 Assim o reconhecem os artigos $5^{\circ} \mathrm{V}$ da Constituição da República Federativa do Brasil e os artigos 927 e 944 e ss., do Código Civil brasileiro, Lei № 10.406, de 10 de janeiro de 2002.

${ }^{126}$ Art. $5^{\circ}$ Todos são iguais perante a lei, sem distinção de qualquer natureza, garantindo-se aos brasileiros e aos estrangeiros residentes no País a inviolabilidade do direito à vida, à liberdade, à igualdade, à segurança e à propriedade, nos termos seguintes: (...) V - é assegurado o direito de resposta, proporcional ao agravo, além da indenização por dano material, moral ou à imagem.
} 
4.

Proposta Jurídica para a melhor interpretação e aplicação do dano moral em ambos os sistemas de direito.

\section{1. \\ Discutir a possibilidade da adoção (não legislativa) do ressarcimento econômico do Dano Moral em Cuba.}

No sistema cubano precisa-se de uma harmonia na hierarquização do aparato legal, devendo ser enaltecida a supremacia constitucional, o que se conseguiria se as normas inferiores se ativessem aos seus postulados. Através da unidade e sistematicidade regulatória, a integridade funcional, os princípios de supremacia constitucional e a hierarquia normativa, pode-se articular a reparação econômica do dano moral, sem a necessidade de uma reformulação legislativa.

A interpretação da figura em questão deve começar na valoração das normas constitucionais, sobretudo aquelas que enaltecem a dignidade da pessoa humana como principal fundamento e lei primeira do Estado cubano. Para justificar a necessidade da reparação do dano extrapatrimonial, resulta suficiente a interpretação do princípio constitucional que guia a sociedade em consonância com o objetivo fundamental da Revolução: "Yo quiero que la ley primera de nuestra República sea el culto de los cubanos a la dignidad plena del hombre". ${ }^{127}$

Apesar de a norma suprema não fazer menção explícita ao dano em análise, no seu artigo 26 consta a concessão à vítima de um dano proveniente da atuação dos funcionários públicos do Estado, do direito de reclamar e obter a correspondente reparação; preceito legal esquecido pelos tribunais cubanos, embora constitua uma norma eficaz que comanda a responsabilidade do Estado e de seus organismos no seu exercício abusivo e injusto. O Estado cubano é responsável por garantir a liberdade e a dignidade plena do homem no exercício de seus direitos e deveres ${ }^{128}$ além disso, a Carta Magna denuncia toda prática lesiva à dignidade humana, estipulando sua respectiva sanção por lei. ${ }^{129}$

O Código Civil cubano deve ser interpretado em observância aos preceitos constitucionais antes debatidos, pois contém artigos que favorecem a tutela do

\footnotetext{
${ }^{127}$ Esta frase se encontra no preambulo da Constituição da República de Cuba, foi expressa por nosso apóstolo José Martí como seu maior anelo, sustentada na Carta Magna cubana.

${ }^{128}$ Ver artigos 9, 16 e 26 da Constituição da República de Cuba.

129 A discriminação por motivo de raça, cor da pele, sexo, origem nacional, crenças religiosas e qualquer outra lesiva à dignidade humana, estão proscritas e são sancionadas pela lei. (CUBA, Constitución de la República de Cuba, 24 de febrero de 1976, art. 42 e 43).
} 
4.

Proposta Jurídica para a melhor interpretação e aplicação do dano moral em ambos os sistemas de direito.

dano moral e sua adequada reparação. Por exemplo, no seu artigo $2^{130}$ dispõe a necessidade de interpretar o Código a partir dos fundamentos políticos, sociais e econômicos expressados na Constituição, sendo a dignidade humana o principal deles. Os artigos 4 e 6 estabelecem o imperativo de que os direitos concedidos aos cidadãos sejam exercidos em correspondência com a finalidade social, proibindo, tanto quanto sancionando em razão de um abuso de direito, os danos causados a outrem, embora presumida a presença de boa-fé em toda relação de direito.

Por outra parte, o artigo $38^{131}$ concede ao lesado e seus herdeiros a faculdade de exigir a reparação integral ante todo dano que afete seus direitos constitucionais, incluída não só a retratação pública do ofensor, senão também o cessamento imediato da violação e a reparação dos danos e prejuízos causados, cabível aqui a noção pecuniária da compensação. Ainda que o artigo 88 estipule que a reparação por dano moral compreende a satisfação do ofendido mediante a retração pública do ofensor, isso não significa que se limite somente a essa forma de reparação, senão que, cada pleito dessa índole leva implícita a retratação pública do lesante. Isso ratifica a incorreta interpretação dos aplicadores do direito em Cuba, ao continuar negando a reparação pecuniária do dano moral a partir da interpretação do artigo 88, tendo-se corroborado que a palavra "compreende", no idioma espanhol, significa abarca, inclui em si, contém, concebe, abraça, implica $^{132}$ e no caso do idioma português tem o mesmo sentido ${ }^{133}$.

Do antes debatido, colige-se que sempre que for apresentado um litígio por dano extrapatrimonial e fique demonstrada a correspondente obrigação de reparar, deve-se dispor da retratação pública do ofensor, além das outras vias concedidas no artigo 38 do próprio corpo legal. $\mathrm{O}$ artigo 88 é, pois, um complemento do artigo 38, tornando a reparação mais completa e justa. O Código Civil não contém nenhum preceito que proíba a compensação econômica do dano moral, sendo possível sua aplicação através da interpretação extensiva do artigo 38. Além disso, a lei substantiva como norma de direito privado, não precisa de um artigo que

\footnotetext{
${ }^{130}$ Trad. Artigo 2. As disposições do presente Código se interpretam e aplicam de conformidade com os fundamentos políticos, sociais e econômicos do Estado cubano expressos na Constituição da República. (CUBA, Constitución de la República de Cuba, 24 de febrero de 1976, art. 2).

${ }^{131}$ Ver artigo 38 da Ley No 59, de 16 de Julio de 1987. Código Civil de Cuba.

132 Ver en el "Diccionario de la Real Academia Española" 23 $3^{a}$ edición 2014. Disponível em: http://www.rae.es/diccionario-de-la-lengua-espanola/la-23a-edicion-2014. Acesso em 01/09/2017. 133 Ver no Dicionário Online de Português. Disponível em: https://www.dicio.com.br/compreende/. Acesso em 01/09/2017.
} 
4.

Proposta Jurídica para a melhor interpretação e aplicação do dano moral em ambos os sistemas de direito.

possibilite de forma explícita a reparação econômica, devendo-se conceder a reparação pecuniária em correspondência com o princípio da dignidade humana.

Apesar de o legislador cubano não ter disposto, de forma clara, como ficaria reparado o dano moral, limitando-se tão somente à redação dos artigos antes mencionados, isso não impede que os juízes, na sua obrigação de emitir uma sentença justa, adotem de forma unificada as normas constitucionais e civis que conformam o sistema legal. É injustificável o fato de que o único artigo que concede a possibilidade de reparação econômica não seja aplicado por não estar regulado dentro dos preceitos que consagram a responsabilidade civil, argumento que desvirtua a funcionalidade do sistema legal como um todo. Desde que exista um litígio dessa natureza, o juiz cubano tem a possibilidade de aplicar o artigo 38 em correspondência com a preceptiva dos artigos 4, 6 e 88 da lei substantiva, bem como à luz dos preceitos constitucionais referentes à dignidade humana, com o fim de conceder a reparação íntegra da vítima através da retratação pública do ofensor e a reparação econômica quando o caso assim o exigir.

Tanto o legislador cubano quanto os juízes, devem reorientar sua função, importando-lhes, a obrigação de criar leis coerentes que guardem correspondência com a realidade socioeconômica e o momento histórico, bem como a responsabilidade na interpretação e aplicação do direito conforme os princípios da justiça, equidade e o iura novit curia. Na interpretação conjunta do artigo 120 da Constituição cubana ${ }^{134}$ e dos artigos 3 e 4 da Lei dos Tribunais, ${ }^{135}$ resta justificada a possibilidade de um juiz, no conhecimento de um litígio por dano moral, conceder uma adequada reparação, fazendo, para isso, uso da interpretação extensiva de todas as leis que conformam o ordenamento jurídico, em especial, daquelas que compõem o texto da lei suprema e que guia seu desempenho. Os juízes têm a obrigação de amparar a vida, liberdade, dignidade, honra, patrimônio, relações familiares, e, outros direitos e interesses legítimos dos cidadãos.

Uma das normas que deve ser usada na fundamentação das sentenças judiciais, naqueles casos em que se conceda reparação por dano moral, é o artigo

\footnotetext{
${ }^{134}$ O artigo 120 da Carta Magna cubana estabelece que a função de ministrar justiça dimana do povo e é exercido em nome deste pelos tribunais. (CUBA, Constitución de la República de Cuba, de 24 de febrero de 1976).

${ }^{135}$ Segundo os artigos 3 e 4 da Lei dos Tribunais, a função de ministrar justiça dimana do povo e é exercida pelos tribunais, entre cujos objetivos principais encontra-se: amparar a vida, liberdade, dignidade, honra, patrimônio, relações familiares, assim como, outros direitos e interesses legítimos dos cidadãos. (Cuba, Ley 82 de los Tribunales Populares de 11 de julio de 1997).
} 
4.

Proposta Jurídica para a melhor interpretação e aplicação do dano moral em ambos os sistemas de direito.

89.1 do Código Civil ${ }^{136}$, introdutório da regulação da responsabilidade civil na lei substantiva. Sua preceptiva dispõe a obrigação de reparar qualquer dano que seja causado e concede ao juiz um papel preponderante na fixação da quantia monetária com o fim de obter a reparação da lesão injustamente causada. Não obstante, o mencionado preceito somente é aplicado ante um dano patrimonial ficando desamparadas as vítimas dos danos morais, embora a norma em análise possa sustentar a decisão judicial que confira a correspondente reparação.

O Decreto Lei $N^{o} 209$ de 2000 pode ser utilizado, de forma complementar, para conceder a adoção pecuniária do dano moral, pois é o único dispositivo legal que no sistema legal cubano introduz a reparação econômica. Ainda que o referido Decreto beneficie somente as vítimas dos danos morais ocasionados pelo governo dos Estados Unidos, sua interpretação deve ser estendida, em sede civil, para todos os danos que infrinjam a dignidade da pessoa, independentemente do autor desse detrimento, ao ser uma norma com menor categoria hierárquica em relação ao Código Civil. O dispositivo citado obriga, no seu artigo $2^{137}$, a reparação integral do dano moral através da adoção da retratação pública, assim como o pagamento de uma quantia monetária de caráter compensatório a favor do lesado. Além disso, concede ao tribunal um arbítrio considerável na reparação do dano moral e regula o dano reflexo mediante pagamento aos familiares até o segundo grau de consanguinidade; adotando de forma análoga os artigos do Código Civil concernentes à reparação do dano moral ${ }^{138}$, questões pelas quais resulta factível sua adoção análoga em sede judicial ante qualquer caso dessa ordem.

No tribunal analisado não existe nenhum litígio interposto contra o referido governo dos Estados Unidos de América, resultando a norma citada com anterioridade, inexecutável na prática judicial cubana, desaproveitando-se assim a inovadora regulação da compensação econômica que poderia ser aplicada em sede judicial. O que se propõe é que seja adotado esse decreto pelo juiz civil tomando

\footnotetext{
136 Trad. Artigo 89.1: As pessoas naturais estão forçadas a reparar os danos e prejuízos que causem ou, sejam causados pelas pessoas por quem devem responder (...) o tribunal, a seu prudente arbítrio, se o responsável é um trabalhador ou pensionista sem bens próprios conhecidos para satisfazer totalmente o importe do dano ou prejuízo, pode adequar a quantia da indenização a um vinte por cento do salário ou qualquer outro ingresso periódico que perceba (...).CUBA, Ley $\mathrm{N}^{\circ}$ 59, de 16 de Julio de 1987. Código Civil

${ }^{137}$ Trad. Artigo 2: (...) a reparação do dano moral compreende o abono de uma suma com caráter compensatório a quem padecem a afetação que o dano lhes provoca e a retratação pública do ofensor. (CUBA, Decreto-Ley 209, de 20 de marzo de 2000).

${ }^{138}$ Ver artigos 5 e 6 do Decreto-Ley 209, de 20 de marzo de 2000.
} 
4.

Proposta Jurídica para a melhor interpretação e aplicação do dano moral em ambos os sistemas de direito.

em consideração a preceptiva da Constituição da República de Cuba que consagra a proteção da dignidade humana como seu principal fundamento. Resulta incompreensível e injusto um tratamento diferenciado do dano moral dependente da condição do lesante, esse tratamento infringe o princípio de igualdade ante a lei ${ }^{139}$, devendo todos os lesados receber uma mesma compensação ante uma violação da mesma natureza, que nesse caso, seria um dano moral.

Em outra ordem de análise, o procedimento estabelecido pela Caixa de Ressarcimento $^{140}$ pode ser empregado na reparação do dano moral. Através da caixa o lesante fica obrigado, respondendo com seus bens, outros proventos ou qualquer obrigação de fazer, diretamente à caixa, a qual ressarce o lesado logo, embora a dívida do ofensor seja paga de forma periódica. Desta forma, evidenciase a possibilidade de que as instituições do Estado também sejam destinadas à reparação do dano moral, sendo obrigação do órgão estatal a proteção da dignidade humana, independentemente da forma pela qual tenha sido ultrajada. $\mathrm{Na}$ Instrução 104 de 16 de fevereiro de 1982 outorga-se à vítima a faculdade de exigir a participação da caixa sempre que existir pendente um atestado de sanidade. Uma vez que o lesado esteja recuperado de suas lesões, é possível que reclame civilmente a indenização de todos os danos sofridos, sendo desnecessário especificar a sua natureza moral ou material. $\mathrm{Na}$ prática judicial só se reparam os danos materiais, esquecendo os juízes da possibilidade de aplicar este mecanismo nas demandas por danos morais derivados da ocorrência de um delito.

O argumento anterior pode consolidar-se por meio do artigo 70.1 do Código Penal ${ }^{141}$, o qual concede ampla proteção ao dano extrapatrimonial ao determinar sua reparação; apesar de a norma não especificar a forma de efetivação, deve-se

139 O princípio de igualdade encontra-se constitucionalmente estabelecido na Constituição da República de Cuba, cuja violação gera uma sanção legal. (CUBA, Constitución de la República de Cuba, de 24 de febrero de 1976, arts. 41 e ss.). Ver no item 2.6, págs. 39 e 40.

${ }^{140}$ A caixa de ressarcimento exerce a função de uma entidade seguradora pertencente ao Estado cubano, ela se subordina ao Ministério de Justiça na sua condição de Fazenda Pública. Quando se manifesta a responsabilidade civil derivada do delito, caso o réu não abone diretamente o valor monetário concedido a favor do lesado, a caixa substitui ao réu no pagamento dos direitos da vítima, e posteriormente exige do sancionado o reembolso da responsabilidade civil que abonou por ele. Ver nas páginas 46-48 do item 2.6.1. E no artigo 71 (CUBA, Ley No 62, Código Penal de 29 de diciembre de 1987) O procedimento da Caixa foi modificado pelo artigo 15 do Decreto Lei 175 de 17 de junho de 1997 aos efeitos de excluir da competência da instituição às pessoas jurídicas, criando-se um vazio legal que até o momento não tem solução. (MEDINA CUENCA, 2013, p. 65)

${ }^{141} \mathrm{O}$ mencionado artigo manifesta que quem seja responsável penalmente também o é civilmente pelos danos e prejuízos causados. Concedendo a faculdade do tribunal que conhece do delito executar diretamente a reparação do dano moral. (CUBA, Ley N 62, Código Penal de 29 de diciembre de 1987, art. 70.1) 
4.

Proposta Jurídica para a melhor interpretação e aplicação do dano moral em ambos os sistemas de direito.

considerar o uso da caixa de ressarcimento tanto para o dano material como para o moral, decorrentes da perpetração de um delito. De igual forma, a Instrução 104, antes mencionada, possibilita o uso da caixa de ressarcimento para as reclamações por pensão alimentícia, aplicando-se de forma supletória as disposições do Capítulo II do Título III do Código de Família, destinado à obrigação de dar alimentos, ${ }^{142}$ os artigos da Lei de Procedimento Civil que concebem o processo de $\operatorname{alimentos}^{143}$, isso tudo aliado ao procedimento aperfeiçoado pela Instrução 117, de 1984, do Conselho do Governo do Tribunal Supremo cubano. ${ }^{144}$

Nessa ordem de análise, o processo de alimentos pode ser implementado para determinar a forma de exercício da reparação pecuniária do dano moral em sede judicial, fazendo uso da interpretação por afinidade dos preceitos normativos regulados pelo próprio sistema jurídico. O artigo 127 do Código de Família estabelece que a quantia concedida, em termos de alimentos, será proporcional à capacidade econômica do compelido e às necessidades de quem os receba. Assim como acontece no Brasil, adota-se a capacidade econômica das partes como critério para determinação do quantum devido. No entanto, a própria norma proíbe que a quantia arbitrada signifique um empobrecimento para quem a desembolsa $^{145}$. De igual forma, pode-se fazer uso das possibilidades que oferece a Lei do Processo Civil em relação à apreensão dos bens pertencentes ao obrigado que não cumpre com a sua responsabilidade. Assim, o beneficiado pode solicitar ao tribunal a apreensão de alguns bens próprios do devedor, com o fim de cumprir sua obrigação, excetuando-se os referidos no artigo 463 desta própria lei ${ }^{146}$

\footnotetext{
${ }^{142}$ Ver artigos 121-131 (CUBA, Ley Nº 1289, Código de Familia, 14 de febrero de 1975)

143 (CUBA, Ley N ${ }^{\circ}$ 7, Ley de Procedimiento Civil, Administrativo, Laboral y Económico de 19 de agosto de 1977, art. 358 ao 371 )

${ }^{144} \mathrm{Na}$ Instrução 117 aperfeiçoa-se a tramitação do processo de alimentos adotando as regras da LPCALE referente à apreensão de bens do devedor, uma vez que descumpra com a sua obrigação. (CUBA, Instrucción N ${ }^{\circ}$ 117, de 11 de outubro de 1984 do Conselho Governo do Tribunal Supremo Popular, disposição primeira, inciso d)

${ }^{145}$ Trad. Art. 127: A quantia dos alimentos será proporcional à capacidade econômica de quem o dá e às necessidades de quem o receba. O tribunal deverá ter em conta, para a adequação da quantia tudo o que o obrigado perceba susceptível de imputar-se ao conceito de alimentos. Em nenhum caso se vão prejudicar os recursos do obrigado a prestar alimentos até o ponto de que não possa satisfazê-los sim desatender suas próprias necessidades e, em seu caso, as de seu cônjuge e filhos menores. (CUBA, Ley No 1289, Código de Familia, 14 de febrero de 1975)

146 Trad. Artigo 463. Poderão ser objeto de apreensão, medida cautelar ou de segurança, toda classe de bens e direitos, com exceção dos que a continuação se expressam: 1) os bens de propriedade socialista estatal; 2) o imóvel que constitua a vivenda permanente do devedor; 3) os bens de propriedade pessoal destinados ao uso imprescindível do devedor; 4) os meios ou instrumentos de trabalho de uso necessário para o exercício da profissão, arte ou ofício; 5) os
} 
4.

Proposta Jurídica para a melhor interpretação e aplicação do dano moral em ambos os sistemas de direito.

O contrato de seguro é outro meio adequado para tornar eficaz a responsabilidade civil, e, no caso de Cuba, para que os órgãos do Estado assumam um papel ativo na sociedade. No Código Civil cubano regula-se o seguro da responsabilidade civil a partir do artigo 463, o qual determina a obrigação do segurador, que seria uma instituição estatal, de indenizar todos os danos e prejuízos ocasionados pelo segurado a terceiros. Nesses casos, existem duas possibilidades, o segurado pode pagar diretamente ao terceiro afetado, ou a instituição seguradora pode restituir a vítima e depois descontar esse valor das prestações pagas pelo segurado. Esse procedimento considera-se uma via infalível para reparar o dano moral, sempre que seja concedida uma reparação econômica.

Isto posto, não será necessária a atuação judicial, pois, através do seguro, assegura-se a reparação da vítima, sem, inclusive, levar o lesante à insolvência; fica, então, garantida a compensação por meio do princípio de solidariedade. Os seguros constituem um meio eficaz para aqueles que desempenham uma atividade geradora de riscos, devendo o segurador suprir a reparação na eventualidade de morte, ou qualquer outro dano que dela derive. Essa reparação coletiva consagra o princípio de solidariedade, pois, todos devem responder e ser partícipes dos danos e riscos que acontecem na sociedade, precisamente porque essas atividades arriscadas geram benefícios à coletividade (DÍEZ PICAZO, 1979, p. 738). O lesante em tais circunstâncias, e sempre que não se comprove sua culpabilidade na produção do dano, deve contar com o apoio da sociedade, incentivando-se, dessa forma, a socialização dos riscos e o chamado a que outras pessoas também exercitem a atividade independentemente de seus possíveis riscos.

De forma similar, o instituto da Seguridade Social, regulado na Lei no. 105 de 2008 pode ter um papel decisivo na reparação do dano moral. Essa instituição confirma a importância da função estatal quanto à defesa e proteção dos cidadãos cubanos. O Estado é o responsável por garantir o funcionamento do instituto para todos os cidadãos, sobretudo, os mais necessitados, dotando-os de recursos materiais, financeiros e humanos. Todos os cidadãos cubanos com vínculo laboral contribuem com seus aportes pessoais ao regime de Seguridade Social, em

veículos que constituam instrumentos o meio de trabalho pessoal; 6) as pensões alimentícias; 7) as terras integrantes do mínimo vital e a área de autoconsumo do pequeno agricultor e os demais bens inerentes a ela, (...). Serão impropriáveis até a terceira parte do salário, e as prestações da seguridade social, mas, nos casos de reclamações de pensões alimentícias e créditos em favor do Estado e as empresas estatais a apreensão poderá se reduzir até a metade do monto desses ingressos. (CUBA, Ley No 5, Ley de Procedimiento Civil de 19 de agosto de 1977) 
4.

Proposta Jurídica para a melhor interpretação e aplicação do dano moral em ambos os sistemas de direito.

resposta ao princípio de solidariedade constitucionalmente reconhecido ${ }^{147}$ e em benefício da sociedade de forma geral. Através das normativas da Lei 113 do ano $2012^{148}$ regula-se no país o sistema tributário, bem como a forma e a quantia despendida na operação. $\mathrm{O}$ objetivo da seguridade social é oferecer proteção às pessoas com impossibilidade temporária ou permanente de obter vencimentos.

Muito embora a dinâmica dessa instituição, aparentemente, não guarde relação com a figura dos danos morais, suas disposições podem ser adotadas na concessão de uma reparação econômica. $\mathrm{O}$ mecanismo da seguridade social pode ser efetivamente aproveitado com base no princípio de solidariedade, respondendo de forma coletiva pelos danos que incidam sobre toda a comunidade; por exemplo, nos casos de danos ocasionados aos direitos difusos, ou também quando se manifeste um dano derivado de riscos. A atividade habitualmente exercida que leva implícita a possível produção de um risco, na maioria dos casos, proporciona frutos para toda a sociedade, e, em consequência, deve-se responder de forma solidária pelos danos que se derivam dessa atividade, mas quando seja provada a culpa do lesante; deve responder de forma individual, pelos efeitos de seus atos.

A lei 105 de 2008 estabelece a forma de quantificação das pensões concedidas às pessoas que se encontram incapacitadas de forma temporária ou permanente para o trabalho, ${ }^{149}$ bem como aos seus dependentes econômicos. ${ }^{150}$ Essas quantias podem ser igualmente aplicáveis nos casos de manifesto dano moral, pois a reparação importa à sociedade de forma geral; são valores monetários que não estão destinados a enriquecer a vítima dos danos, senão que minoram os efeitos do evento ao qual foi submetida. Uma vez afrontada a dignidade humana de um indivíduo, tendo sido também comprometido o seu patrimônio, então se deve conceder a reparação econômica de ambos os danos. No sistema cubano, como se tem confirmado, o lesado só recebe proteção por dano patrimonial, de modo que se ressarce a vítima não pela afetação à sua integridade psicofísica, senão pela diminuição que esse prejuízo provocou no seu patrimônio.

O que fica claramente demonstrado é que existem vias suficientes para determinar a definição acertada do dano moral, em razão de lesão infringida de forma injusta, a partir do princípio e valor constitucional da dignidade humana. $\mathrm{E}$

\footnotetext{
${ }^{147}$ Ver art. 1 da Constituição cubana.

148 (Cuba, Ley no. 113 del Sistema Tributário,23 de junio del 2012)

149 Ver artigos. 48-69 (Cuba, Ley de la Seguridad Social no. 105, 27 de diciembre del 2008)

${ }^{150}$ O artigo 39-41e 70-86 (Cuba, Ley de la Seguridad Social no. 105, 27 de diciembre del 2008)
} 
4.

Proposta Jurídica para a melhor interpretação e aplicação do dano moral em ambos os sistemas de direito.

uma vez corroborada a existência dos elementos que compõem a responsabilidade civil, demanda-se a reparação integral do lesado, através da retração pública do ofensor e por meio de uma reparação pecuniária, a qual pode seguir as regras estabelecidas para o Processo Sumário de Alimentos. Dessa forma, verifica-se que o maior problema na aplicação do dano moral em Cuba não é tanto as leis existentes no país, senão a interpretação desacertada que realizam os juízes. Como restou demonstrado, existem várias alternativas que possibilitam a aplicação pecuniária da reparação do dano extrapatrimonial, mas essas vias só se destinam à reparação dos danos materiais, obstando, assim, a figura do dano moral.

Tendo em vista a unidade interna do ordenamento jurídico, e a coerência essencial de seus ditados de conduta, demanda-se a adequada interpretação e reparação do dano extrapatrimonial. Fazendo uso das normas que conformam o sistema legal cubano na proteção à pessoa, principalmente à sua dignidade, seja pelas vias sumárias ou primárias, substantivas ou adjetivas, pertençam elas à rama constitucional, administrativa, civil, laboral etc., é preciso mencionar que todas se complementam, suas intenções na proteção de interesses são semelhantes, seguindo os mesmos postulados ideológicos e éticos. Se bem é certo que as leis existentes em Cuba estão formuladas sob um arraigado conteúdo político, ratificador do caráter socialista fundado, isso não pode figurar uma restrição para a necessária proteção dos interesses existenciais, devendo o sistema político estar em uma segunda ordem de atenção com relação à proteção da dignidade humana.

\section{2. \\ Possibilidade de utilização contemporânea da retratação pública, pode-se entender como direito de resposta prevista na Constituição Federal?}

Em relação ao sistema brasileiro, ficou corroborado que a reparação do dano extrapatrimonial tem amplo reconhecimento civil e constitucional, radicando o problema na sua aplicabilidade em sede judicial. Os juízes, na maioria dos casos, não levam em consideração a magnitude do detrimento nem valoram de forma adequada os parâmetros que conformam a responsabilidade civil. A partir desses elementos, demanda-se uma efetiva compensação da pessoa que foi atingida na sua dignidade em virtude de um dano grave e injusto. Além disso, os juízes concedem tutela jurídica a qualquer dano que lhes seja exibido, sem propriamente 
4.

Proposta Jurídica para a melhor interpretação e aplicação do dano moral em ambos os sistemas de direito.

configurar-se um prejuízo moral, o qual é neutralizado, com uma soma monetária excessiva, não se adotando outras vias de possível reparação do lesado.

Por esses motivos, é imperativa uma mudança na concepção e aplicação dessa figura de direito, sobretudo no que concerne à sua compensação em sede judicial. Apesar de os juízes brasileiros, na sua árdua e difícil função, venham demonstrando um nível de consideração e de tutela do indivíduo completamente superior ao concedido no sistema judicial cubano deve ser reconsiderada a escolha dos assuntos que merecem tutela jurídica e a forma em que será ressarcida a vítima, sendo eficaz a análise do artigo 5 da Constituição, consagrador dos direitos e garantias fundamentais, entre os quais figura o direito de resposta ${ }^{151}$ :

O direito de resposta é aquele que faculta à pessoa ofendida a requerer que quem publicou a matéria lesante, também divulgue uma resposta proporcional, na qual é contada a versão da vítima. Assim, obriga-se ao ofensor a publicar, nas mesmas condições, o desmentido ou a versão corretiva do equívoco original. ${ }^{152} \mathrm{O}$ direito de resposta é um instrumento democrático moderno que visa proteger a pessoa de imputações ofensivas e prejudiciais a sua dignidade e sua honra. ${ }^{153}$

Precisa-se da interpretação ampla do direito de resposta, de modo a ser subentendida a figura da retração pública que se traduz em uma desculpa pública $^{154}$ ou divulgação da retratação do ofensor; caso contrário, em sendo interpretado de forma estrita, restaria abarcado tão somente o direito do ofendido a defender-se das manifestações não certas ou errôneas que lesaram sua dignidade. O direito de resposta é um direito geral que abarca não só a legítima defesa do ofendido, de forma proporcional e nos mesmos termos em que foi lesado; mas também, impõe a retratação de quem se manifestou de forma pública, quando vier a prejudicar injustamente a dignidade alheia. A retratação pública considera-se uma espécie incluída na figura gênero do direito de resposta, mas seu exercício

\footnotetext{
${ }^{151}$ Art. $5^{\circ}$ Todos são iguais perante a lei, sem distinção de qualquer natureza, garantindo-se aos brasileiros e aos estrangeiros residentes no País a inviolabilidade do direito à vida, à liberdade, à igualdade, à segurança e à propriedade, nos termos seguintes: (...) V - é assegurado o direito de resposta, proporcional ao agravo, além da indenização por dano material, moral ou à imagem. (BRASIL. Constituição da República Federativa do Brasil, de 5 de outubro de 1988)

${ }^{152}$ Segundo expõe Miragem. Bruno: $O$ direito de resposta e os erros de resposta do direito: http://emporiododireito.com.br/o-direito-de-resposta-e-os-erros-de-resposta-do-direito/. Acesso em 01/09/2017.

${ }^{153}$ Conceito esgrimido por MIRANDA, Darcy Arruda. Comentários à Lei de Imprensa. São Paulo: RT, 1994. In: (BONISSONI, 2011)

${ }^{154}$ https://www.dicio.com.br/retratacao/ Acesso em 05/09/2017.
} 
4.

Proposta Jurídica para a melhor interpretação e aplicação do dano moral em ambos os sistemas de direito.

lhe é inerente ao lesante. Confere-se à vítima a faculdade de responder as notícias ofensivas, e exigir o dever da retratação pública do ofensor.

A Lei de Imprensa no. 5.250, de 9 de fevereiro de 1967, determinava a obrigação de reparar um dano moral fazendo uso do direito de resposta, por meio da publicação ou transmissão da resposta ou retificação por parte do ofendido, assim como a publicação ou divulgação de retratação do ofensor. ${ }^{155}$ Aliás, a citada norma foi declarada incompatível com a Constituição Federal pelo julgamento da ADPF 130, junto ao Supremo Tribunal Federal, no dia 30 de abril de $2009 .^{156}$ Posteriormente, a Lei 13.188, de 11 de novembro de 2015, complementou à norma superior do estado brasileiro, em seu artigo $5 \mathrm{~V}$, na regulação do direito de resposta ou retificação, gratuita e proporcional ao agravo do ofendido. No seu artigo 13, outorga a retratação pública sempre que o ofensor na veiculação da notícia praticasse calúnia ou difamação contra um terceiro. ${ }^{157}$

A Lei 13.188 de 11 de novembro de 2015, no seu artigo 3, possibilita a aplicação conjunta do direito de resposta, retificação, e a retratação pública, com a correspondente reparação do dano moral ${ }^{158}$. Dessa forma, resguarda-se a equidade processual das partes, franqueando-se tanto o conhecimento público das revelações feitas por elas, quanto às convicções mais diversas sobre o assunto. Por meio da utilização desse direito, pode-se esclarecer a notícia difamatória, oferecer ao público detalhes do assunto, obtendo-se, assim, uma maior justiça na reparação do dano moral, não só pela efetiva comprovação do dano provocado, da culpa de quem o proferiu e do nexo causal entre esses elementos, senão também em face da consideração do princípio da boa-fé que deve dirigir toda relação social.

\footnotetext{
155 Artigo 30 (BRASIL. Lei No 5.250, Liberdade de manifestação do pensamento e de informação, de 7 de fevereiro de 1967).

${ }^{156}$ Por maioria, o Supremo Tribunal Federal (STF) declarou que a Lei de Imprensa (Lei $\mathrm{n}^{\circ}$ 5250/67) é incompatível com a atual ordem constitucional (Constituição Federal de 1988). http://www.stf.jus.br/portal/cms/vernoticiadetalhe.asp?idconteudo=107402 Acesso em 20/09/2017. ${ }^{157}$ Parágrafo único do Art. 13: Nos casos em que o querelado tenha praticado a calúnia ou a difamação utilizando-se de meios de comunicação, a retratação dar-se-á, se assim desejar o ofendido, pelos mesmos meios em que se praticou a ofensa. (BRASIL. Lei $\mathrm{N}^{\circ} 13.188$ de 11 de novembro de 2015). Esse artigo foi acrescido a partir do artigo 143 do Decreto Lei $\mathrm{n}^{\mathbf{o}} 2.848$ de 7 de dezembro de 1940, Código Penal já revougado, o qual isentava de cumprir pena aos que exerceram, antes da sentença, a retratação pública da calúnia ou difamação, mas, o texto constitucional no seu artigo $5 \mathrm{~V}$ concede o direito de resposta além da reparação por dano moral e material, pelo qual, colige-se que essas vias podem ser adotadas de forma conjunta na reparação.

${ }^{158}$ Art. $2 \S 3^{\mathrm{o}}$ A retratação ou retificação espontânea, ainda que a elas sejam conferidos os mesmos destaque, publicidade, periodicidade e dimensão do agravo, não impedem o exercício do direito de resposta pelo ofendido nem prejudicam a ação de reparação por dano moral. (BRASIL. Lei $\mathrm{N}^{\circ}$ 13.188, Sobre o direito de resposta ou retificação do ofendido em matéria divulgada, publicada ou transmitida por veículo de comunicação social, de 11 de novembro de 2015)
} 
4.

Proposta Jurídica para a melhor interpretação e aplicação do dano moral em ambos os sistemas de direito.

A responsabilidade civil sobre a notícia veiculada tanto pode recair sobre quem a noticiou quanto ao jornalista responsável pela informação. Assim ficou equiparado por entendimento do STJ ao exigir a responsabilidade pelo ressarcimento do dano moral, decorrente da publicação pela imprensa, tanto o autor do escrito quanto o proprietário do veiculo de publicação (BONISSONI, 2011, p. 95) (SANSEVERINO, 2011, p. 72). Em algumas decisões do TJRJ interpreta-se o direito de resposta em sentido amplo, incluindo a publicação da sentença, a retratação pelo ofensor, e a resposta do ofendido, que seria o direito de resposta em sentido estrito ${ }^{159}$.

A Apelação Cível No 0009376-06.2013.8.19.0210 do dia 8 de fevereiro de 2017 do TJRJ, trata sobre a demanda pela veiculação de matéria jornalística na qual o autor é apontado, indevidamente, como "baderneiro" e "meliante", preso por envolvimento em confusão em frente ao estádio de futebol São Januário. O autor encontrava-se na fila da bilheteria do estádio, quando presenciou confusão entre torcedores e, por conta disso, foi convidado pela polícia para que fosse até a delegacia policial como testemunha. Na reportagem em foco, o autor aparece sendo encaminhado por policiais até uma viatura, ao mesmo tempo em que foi veiculada a seguinte narração do repórter: "Este torcedor brigou com outro por causa de um ingresso. Acabou preso pela polícia militar." O Relator: Des. Fernando Cerqueira Chagas, adotou a reparação do dano moral e a aplicação do direito de resposta, dispondo a retratação pública dos lesantes:

Ainda que seja desarrazoado obrigar os veículos de informação a divulgar os acontecimentos após a plena e exauriente verificação acerca dos fatos noticiados, impõe-se-lhe diligência e cautela na divulgação da notícia com uma análise prévia de cunho investigativo a fim de respeitar a verdade dos fatos. (...) Todavia, no caso em comento, a veiculação da notícia, divorciada da verdade dos fatos, extrapolou a livre manifestação do pensamento e o acesso à informação que, embora assegurados no art. $5^{\circ}$, incs. IV e XIV, da CF, não ostentam caráter absoluto. Por fim, a retratação determinada na sentença revela-se adequada tendo em vista o alcance da notícia e a gravidade da ofensa, motivo pelo qual reclama amplo esclarecimento no meio social quanto ao equívoco da informação divulgada. ${ }^{160}$

Igualmente aconteceu na Apelação Cível No 0050893-85.2014.8.19.0038 do dia 9 de maio de 2017. Nela a autora solicitava indenização por dano moral, alegando que o jornal réu, publicou reportagem de que estaria entre os envolvidos

\footnotetext{
159 (Carvalho Leite, Fábio. Liberdade de Expressão versus Direito à Honra: O Direito de Resposta como sanção preferencial. Pág. 16, MIMEO)

${ }^{160} \mathrm{http}: / /$ www1.tjrj.jus.br/gedcacheweb/default.aspx?UZIP=1\&GEDID=00048F3A82E08E8D909 ACF78EF79BBD787B3C506051A0644 Acesso em 5/09/2017.
} 
4.

Proposta Jurídica para a melhor interpretação e aplicação do dano moral em ambos os sistemas de direito.

em supostas irregularidades praticadas pela administração da Prefeitura Municipal de Belford Roxo, teria lhe causado constrangimento em razão da utilização de expressões como "falcatrua" ou mesmo entre os "denunciados". O Relator

Desembargador José Roberto Portugal Compasso entendeu que:

Em se tratando de matéria veiculada pela imprensa, a responsabilidade civil por danos morais exsurge quando o texto ou a imagem publicada evidenciam a intenção de injuriar, difamar ou caluniar terceiro ou quando evidente o abuso do direito de informar, o que ocorre quando são publicadas notícias inverídicas. No caso concreto, restou evidenciada a malícia proposital, ao colocar o nome do apelante entre os "denunciados", como estando envolvido na "falcatrua" que diz estar pairando sobre o concurso realizado pela Prefeitura do município. (...) Ao invés de divulgar a manifestação do autor, a ré manifesta-se ironizando, propositalmente, a resposta do autor, eximindo-se dos fatos publicados anteriormente por ela e afirmando. Mostra-se evidente a violação do direito de resposta por parte da ré, não tendo sido assegurado ao apelante a oportunidade de se manifestar prontamente perante os leitores da apelada. (...) dou provimento ao recurso (...) condenando a parte ré no pagamento da quantia de $\mathrm{R} \$ 3.000,00$ reais a título de compensação por danos morais (...) além do dever de se retratar e conceder à parte autora o direito de resposta nos termos da matéria veiculada. ${ }^{161}$

Justifica-se a aplicação da retratação pública no Brasil como forma do exercício constitucional do direito de resposta, uma opção legítima para resolver os conflitos no quais se encontra violada a dignidade da pessoa humana. A utilização da retratação pública não só se limitaria aos conflitos suscitados entre liberdade de imprensa e honra ou imagem, podendo ser adotada, desde que essa ofensa fosse injusta e grave, transgressora da boa-fé e do princípio geral neminem laedere, sempre e quando atingida a dignidade de uma pessoa por causa dessa notícia ou manifestação. A retração pública, corretamente aplicada, seria um mecanismo eficaz no amparo da honra, intimidade, e da dignidade humana, cujo exercício permite uma diminuição considerável das decisões judiciais que concedem reparação pecuniária e das quantias concedidas nas sentenças.

Em consonância com o professor Fábio Carvalho Leite, há a necessidade de que os juízes brasileiros adotem o direito de resposta como sanção preferencial em relação ao pagamento de indenização por danos morais ${ }^{162}$. Ante uma lide dessa

\footnotetext{
${ }^{161}$ http://www1.tjri.jus.br/gedcacheweb/default.aspx?UZIP=1\&GEDID=0004DA21F2505AEE0CC90 E1ED0EFC8793AFEC506290F0911 Acesso em 5/09/2017.

162 O professor mencionado tem realizado vários experimentos onde pretende demonstrar a possibilidade da adoção do direito de resposta como via legítima para dirimir conflitos entre liberdade de imprensa, honra e imagem e como via legítima a ser adotada pelos tribunais brasileiros incidindo positivamente na diminuição das sentenças concedendo pagos monetários ante um dano moral ocasionado, e incentivando o direito do lesado à liberdade de expressão. (Carvalho Leite, Fábio. Liberdade de Expressão versus Direito à Honra: O Direito de Resposta como sanção preferencial. Pág. 3, MIMEO)
} 
4.

Proposta Jurídica para a melhor interpretação e aplicação do dano moral em ambos os sistemas de direito.

natureza devem ser valoradas as características de cada caso, examinando-se o assunto concreto em face dos elementos da responsabilidade civil e assim determinar a melhor forma de reparar a vítima desse fato danoso. Nem sempre a reparação econômica vai ser a única, ou melhor opção para compensar o lesado. Quando o dano causado for originário da internet, decorrer da veiculação de informações pelos meios de comunicação social ou remeter à esfera laboral, o direito de resposta e a retratação pública do ofensor do evento lesivo constituem vias adequadas de reparação, ainda melhores que a compensação em dinheiro.

O direito de resposta pode ser adotado sempre que se manifeste uma notícia falsa ou errônea, independentemente da configuração do dano moral. Tal e como aconteceu na decisão adotada no TJRJ, $7^{\text {a }}$ Câmara Cível, AC n. ${ }^{\circ}$ 009285687.2014.8.19.0001, de relatoria do Desembargador André Andrade. Nesse assunto o apelante interpôs ação de indenização por dano moral com retratação em face de ESPN do Brasil Eventos Esportivos LTDA. A reportagem declarava que o apelante percebia uma remuneração de $\mathrm{R} \$ 7.100,00$, valor superior ao qual realmente fazia jus. O lesado manifestou que a reportagem era inverídica, ultrapassando os limites da liberdade de imprensa. Sustentou a ocorrência de dano moral e pediu a condenação da ré à retratação e ao pagamento de indenização por dano moral. A sentença de primeira instância julgou improcedente o pedido, sendo modificado na segunda instância que apesar de não considerar o dano moral, concedeu o direito de resposta:

(...) não se vislumbra dano de ordem patrimonial nem extrapatrimonial, pela inexistência de abalo à honra do autor, bem como pela não caracterização de dor, ou de qualquer ato atentatório contra a intimidade, a vida privada, a imagem, ou a qualquer outro direito da personalidade, passível de ressarcimento. Embora não configurado o dano moral, forçoso reconhecer que a matéria apresentou uma imprecisão no valor divulgado como salário percebido pelo autor. Desta feita, impõe-se conceder ao autor o direito de resposta, quanto a este aspecto. Registre-se que a publicação deverá ser promovida a critério do autor em sede de cumprimento de sentença. (...) concedendo o direito de resposta ao autor, ora apelante, para que seja publicado o valor correto do salário recebido pelo mesmo.

Embora verídico o argumento de que o direito de resposta e o dano moral são institutos diversos e autônomos, porém, a finalidade da presente dissertação radica propriamente na figura do dano moral, e precisamente deve-se aproveitar o amplo potencial do direito constitucional de resposta para efetivar a reparação

\footnotetext{
${ }^{163}$ http://www1.tjri.jus.br/gedcacheweb/default.aspx?UZIP=1\&GEDID=00044CB55A4E7DAB92
} 50DA9DC3DBAC5536D6C5044A42315F Acesso em 05/09/2017. 
4.

Proposta Jurídica para a melhor interpretação e aplicação do dano moral em ambos os sistemas de direito.

judicial pelas diversas variantes que permitam a compensação mais completa do lesado. Configurado um dano moral pela veiculação ou manifestação pública de notícias ou informação graves e lesivas da dignidade humana, corresponde fazer uso do direito de resposta, que nesses termos, incluiria a possibilidade de que o lesado exercesse seu legítimo direito de defesa ou retificação da informação lesante, mas também que seja disposta a retratação pública do ofensor.

Dessa forma, vai se conceder uma tutela mais ampla à pessoa lesada, quem pode solicitar a retratação pública da pessoa que veiculou ou manifestou uma notícia transgressora de sua dignidade. A veracidade da notícia não eximiria ao ofensor da sua correspondente responsabilidade, sendo preciso ponderar o direito à informação e o direito existencial lesado. Toda relação humana deve basear-se no princípio da boa-fé, devendo-se responder pelo abuso do direito que atenta contra o alterum non laedere existente na sociedade. Por meio da retratação pública e do direito de resposta, a reparação de um dano moral pode ser feita de forma íntegra, seja pela sua configuração independente da reparação pecuniária, ou pela adoção de ambas as vias quando as circunstâncias assim o exigirem.

Mediante a retratação pública de qualquer meio das redes sociais, possibilita-se uma reparação efetiva da dignidade humana violada, que será ressarcida da mesma forma em que foi contravinda. O meio de difusão que divulgue notícias falsas, e posteriormente seja ordenada judicialmente a sua retratação, deixa de ser considerado como uma fonte idônea de obtenção de informação, começando a ser percebido como um meio pouco sério e confiável. Uma reparação pecuniária sustentada no caráter punitivo, não seria suficiente para que ficasse ressarcida a vítima de forma íntegra. O objetivo da responsabilidade civil não versa no castigo do ofensor, senão que tem como principal anelo o ressarcimento do lesado da forma mais ampla possível.

Uma vez configurado um dano moral causado nas condições previamente expostas, o juiz deve aplicar a retratação pública, logrando uma reparação mais proporcional, natural e adequada em relação ao prejuízo provocado. Quando se configure uma calúnia, injúria ou difamação na notícia manifestada, o juiz deve aplicar o direito de resposta, interpretado de forma ampla, assim, o público não só conhecerá das alegações das partes do litígio, senão que apreciará qual das argumentações proferidas carece de veracidade. De igual forma, é responsável quem manifestou a notícia que, embora certa, atinge de forma abusiva os 
4.

Proposta Jurídica para a melhor interpretação e aplicação do dano moral em ambos os sistemas de direito.

princípios da boa-fé e do alterum non laedere (SANSEVERINO, 2011, p. 68). Isso não significa um afastamento do direito à informação do público, nesses casos, corresponde ao magistrado ponderar qual dos direitos merece uma maior proteção, precisa-se, portanto, de escolher o que deve ser conhecido pelo público e aquilo que necessariamente tem que ser de conhecimento público.

\section{3. Possibilidade da adoção (não legislativa) da retratação no Brasil por meio da aplicação do Direito Civil-Constitucional}

A retratação pública no Brasil pode ser adotada mediante a interpretação e aplicação do Direito Civil-Constitucional. A necessidade da interpretação da norma substantiva a partir dos princípios constitucionais vem sendo ressaltada por parte da doutrina brasileira ${ }^{164}$. A própria dinâmica do sistema jurídico e a interpretação unificada do aparelho legal exigem a aplicação de toda norma, tomando em consideração as regras constitucionalmente estabelecidas. Dessa forma, pretende-se enaltecer a supremacia das normas constitucionais e o imperativo de interpretar e aplicar toda norma jurídica ordinária, sobretudo o Código Civil, à luz desses preceitos. Nesse sentido, o sistema normativo vai sendo entendido na sua união insolúvel e harmônica, para brindar a mais adequada significação e aplicação do dano moral em sede judicial.

Para a adoção da retratação pública pelo órgão judicial brasileiro não resulta imprescindível a promulgação de uma lei que regule seu exercício, ao contrário, deve-se aproveitar o conteúdo das normas que compõem o arcabouço jurídico e que, no caso do Brasil, concedem imensa proteção à pessoa humana. A partir dos artigos da Constituição resta configurado o princípio fundamental da dignidade humana, enaltecido, ainda, como objetivo fundamental do Estado brasileiro, o qual garante a igualdade e a inviolabilidade dos principais direitos do ser humano. Ante a violação dos preceitos constitucionais previamente consignados, a Constituição assegura o direito de resposta proporcional ao agravo, além da indenização por dano material, moral ou à imagem ${ }^{165}$.

\footnotetext{
164 Assim o concebem Maria Celina Bodin de Moraes e Gustavo Tepedino, explicando a necessidade da aplicação do direito civil-constitucional, através de cujo entendimento fica superada a dicotomia direito público-direito privado. (BODIN DE MORAES, 1993)

${ }^{165}$ Todas estas considerações encontram-se estipuladas nos artigos $1,3,5$ e 6 da Constituição Da República Federativa do Brasil.
} 
4.

Proposta Jurídica para a melhor interpretação e aplicação do dano moral em ambos os sistemas de direito.

A partir dos referidos artigos constitucionais, restou-se comprovado o objetivo do Estado brasileiro na criação de uma sociedade justa, onde o homem seja beneficiado e enaltecido em sua categoria humana digna. $\mathrm{O}$ dano moral desfruta amparo constitucional, cuja reparação, como foi mencionado, encontra-se regulada no artigo $5 \mathrm{~V}$ da Carta Magna. A partir da interpretação desse preceito, justifica-se a adoção da retratação pública, a que embora não se mencione de forma expressa na Constituição, está inserida no conceito do direito de resposta.

Sob tal perspectiva, o dano moral ocupa um lugar predominante, cuja eficácia depende da reparação do ser humano lesado, uma vez levadas em consideração todas as vias possíveis que propiciem sua compensação íntegra, não só através da reparação econômica, senão também fazendo uso de todos os mecanismos constitucionais concedidos com esse fim, entre os quais, figura a retratação pública do ofensor. Adotada sob a ótica do direito civil-constitucional, pode-se, com ela, exigir um determinado comportamento reparatório de quem injustamente infringiu o princípio constitucional da dignidade humana. Tenha-se em consideração que o dano moral, propriamente dito, não se regula de forma explícita pelo Código Civil brasileiro, mas sua interpretação e aplicação derivaram-se dos preceitos constitucionais que dispuseram a imperiosidade de sua adoção, percebendo sua reparação pecuniária.

Assim, a Lei Suprema brasileira incidiu de forma contundente na consagração da figura em estudo, propiciando sua reparação econômica, o que até então não se havia reconhecido; também concebeu outras formas de desagravo, tal como a retratação pública do ofensor, justificada sua adoção em sede judicial. Os preceitos da Constituição brasileira revitalizaram o conteúdo das leis civis. No caso do Código Civil brasileiro, mesmo tendo sido concebido posteriormente ao texto constitucional, não é possível recusar os princípios da lei superior, ao contrário, ele deve estar submetido às regras do texto maior, ou seria qualificado como uma norma inconstitucional, resultando ineficaz sua utilização.

Os atos das pessoas não precisam estar regidos por normas paternalistas que limitem o exercício de seus direitos, mas devem guardar correspondência com o espírito da máxima lei imposta na sociedade, de modo que os atos privados não ocasionem um dano injusto a outrem. A dinâmica do direito civil-constitucional repousa na necessidade de que nenhuma lei inferior possa contravir os princípios constitucionais, cujo objetivo principal é a constituição de um ser humano digno. 
4.

Proposta Jurídica para a melhor interpretação e aplicação do dano moral em ambos os sistemas de direito.

Tem-se como propósito a superioridade da norma constitucional, cuja base determina a validade do ordenamento jurídico. Precisa-se da interação indissolúvel de suas regras e princípios com os preceitos civis, podendo em muitos casos, justificar as decisões judiciais quando a solução do conflito não se verifique na norma civil. Esse seria o contexto da retratação pública, que apesar de não se encontrar regida pela lei substantiva, tem seu tratamento constitucional facilitado pelo direito de resposta; resta, pois, facultada a sua imediata utilização pelos juízes encarregados de solucionar litígios em que estejam envolvidas condições inerentes ao ser humano; assim o explica a professora Maria Celina:

Os princípios e valores constitucionais devem se estender a todas as normas do ordenamento, sob pena de se admitir a concepção de um "mondo in frammenti", logicamente incompatível com a ideia de sistema unitário. (BODIN DE MORAES, 1993)

$\mathrm{Na}$ argumentação de um direito civil-constitucional, os juízes cumprem um papel determinante; por meio de sua função, eles podem valorar os direitos fundamentais transgredidos nas relações privadas. Como se sabe, as regras constitucionais estão destinadas à regulação, tanto presente como futura, do sistema em que se encontram inseridas. Evita-se, por isso, a sua constante modificação, devendo-se, ao contrário, manter seu espírito e condicionar as novas leis à sua própria dinâmica. A função dos juízes é procurar, da melhor forma, a ponderação dos princípios constitucionais. Tal como adotaram a reparação pecuniária do dano moral, deve ser aceita a retratação pública em sede judicial, de forma que a interpretação extensiva da Constituição possibilite outros meios capazes de reparar plenamente à vítima de um dano moral.

A Constituição do Brasil criou um novo direito civil, fazendo-se imperiosa a releitura de todas as normas que compõem o sistema jurídico. Tendo em consideração a norma suprema, os valores das normas constitucionais devem reger a aplicação de toda norma infraconstitucional (LEWICKI, 2003). Além disso, sob a perspectiva do direito civil-constitucional, solidifica-se a prevalência das relações existenciais sobre as patrimoniais, justificados todos os mecanismos pelos quais resulte possível o amparo da pessoa pelo sistema legal, sempre e quando estiverem em correspondência com os postulados constitucionais.

Com a aplicação da retratação pública como meio efetivo de reparação, possibilita-se o ressarcimento da pessoa atingida nos seus aspectos existenciais de uma forma mais proporcional. Como anteriormente mencionado, o direito 
4.

Proposta Jurídica para a melhor interpretação e aplicação do dano moral em ambos os sistemas de direito.

atingido não é mensurável em dinheiro, sendo a restituição pecuniária uma opção válida para diminuir ou minorar o prejuízo causado. No entanto, com a adoção da retratação pública permite-se que a pessoa lesada seja colocada na situação em que se encontrava antes da aferição do dano; embora possa não se expressar com sinceridade, a retratação do ofensor implica, ao menos, o conhecimento por parte de terceiros, que podem desconsiderar as ofensas feitas pelo causador do dano, posicionando-se em relação ao assunto. Isso não significa que a reparação pecuniária seja afastada, ao contrário, o que se pretende é a adoção de ambos os meios de compensação a depender das particularidades do litígio.

O princípio e valor fundamental da dignidade humana, como cláusula geral de tutela da pessoa humana possibilita a adoção de um direito civil-constitucional (BODIN DE MORAES, 2006, p. 2 e 16), através do qual é concedido amparo judicial àqueles casos que merecem uma tutela jurídica. Essa valoração resulta imprescindível devido à quantidade de demandas apresentadas por dano moral, as quais recebem amparo jurídico em sede judicial e são neutralizadas com excessivas quantias monetárias. Dessa compreensão, deriva-se o conceito do dano moral, que segundo a perspectiva constitucional, traduz-se na violação do direito à dignidade humana (CAVALIERI FILHO, 2004, p. 94).

O autor italiano Pietro Perlingieri advoga pela interpretação do direito civilconstitucional, devendo-se sempre aplicar a norma civil à luz da normativa superior (PIETRO, 2008, p. 574), o que propicia a funcionalidade harmônica do sistema, e o respeito pela lei hierarquicamente superior. Dessa forma, pode ser entendida a aplicação da retratação pública em sede judicial brasileira, pois, embora não se estipule na norma ordinária infraconstitucional, encontra-se concebida pela Carta Magna, não existindo proibição alguma que impossibilite a utilização das normas constitucionais. A justificação da adoção da retratação pública pelo sistema brasileiro, em virtude da argumentação do direito civilconstitucional, fica explicada por Perlingieri, nos seguintes termos:

Não existem, portanto, argumentos que contrariem a aplicação direta dos princípios constitucionais: a norma constitucional pode, mesmo sozinha (quando não existirem normas ordinárias que disciplinem a fattispecie em consideração) ser a fonte da disciplina de uma relação jurídica de direito civil (...) seja na aplicação dita indireta (...) seja na aplicação dita direta (...) a norma constitucional acaba sempre por ser utilizada (...). (PIETRO, 2008, p. 589-590) 
4.

Proposta Jurídica para a melhor interpretação e aplicação do dano moral em ambos os sistemas de direito.

A interpretação e aplicação do dano extrapatrimonial nos ordenamentos estudados, deve ser entendida a partir da violação da dignidade da pessoa humana, decorrente de um ato injusto capaz de provocar um prejuízo que atente contra o princípio alterum non laedere e que seja o suficientemente grave para obter amparo judicial. Uma vez determinados esses aspectos exige-se a reparação do lesado, que pode ser exercida através da retratação pública do ofensor, inserida no direito de resposta; a reparação pecuniária proporcional à magnitude do evento causado; além de ser possível a utilização de ambas as possibilidades em um mesmo caso, com o fim de tornar mais íntegra e justa a reparação do lesado.

As propostas apresentadas não precisam ser regulamentadas em leis infraconstitucionais, pois todas elas se derivam do princípio e valor constitucional da dignidade humana, justificando-se sua eficácia plena e aplicação imediata nos sistemas de direitos avaliados. Com a presente dissertação não se pretende adotar uma postura preferente com relação a um dos ordenamentos pesquisados. Demonstrou-se que ambos inclusive, apresentam imperfeições na interpretação e aplicação do dano moral. No caso de Cuba, não se repara o dano moral devido à desacertada interpretação judicial, trazendo como consequência a desproteção do lesado. E no caso do Brasil contrariamente acontece uma indústria do dano moral ao ressarcirem-se economicamente todos os pleitos apresentados, banalizando-se assim a figura em análise, que termina por perder sua finalidade e essência.

Advoga-se por tomar os aspectos positivos existentes em cada sistema de direito no concernente à interpretação do dano moral e as vias pelas que resulta possível a compensação do lesado. Tanto a reparação pecuniária quanto a retratação pública podem ser utilizadas pelo magistrado para lograr a efetiva reparação da vítima. Ambas as vias podem fundamentar as sentenças judiciais, tanto de Cuba quanto do Brasil; podendo coexistir no mesmo assunto ou aplicarse de forma independente de acordo com as características da lide. 


\section{5. \\ Conclusão}

A partir das ideias apresentadas na presente dissertação, tendo como bússola o estudo do dano moral lesador do princípio da dignidade humana nos sistemas jurídicos, cubano e brasileiro, foi possível identificar as seguintes conclusões:

Foi realizada uma análise do dano moral em ambos os ordenamentos jurídicos. Em Cuba verificou-se que embora o dano extrapatrimonial não encontre uma estipulação explícita na Constituição pode ser fundamentado e justificado pelo princípio da dignidade humana, estabelecido no preâmbulo da Carta Magna, o qual constitui a lei primeira do Estado cubano cuja violação demanda uma iminente reparação a favor do lesado.

Observou-se que, em Cuba os tribunais concedem a reparação de um dano moral por meio da retratação pública do ofensor, porém, o tribunal pesquisado, nos últimos 10 anos, não tem adotado essa forma de reparação, pois, só conheceu de um litígio dessa natureza, decidindo de forma desacertada ao não perceber o dano injusto como gerador do prejuízo, reafirmando a percepção arcaica de que a lesão moral só se evidencia ante um ato ilícito traduzido na violação de uma norma, não abrangendo o dano injusto violador do princípio alterum non laedere.

Por meio da análise feita foi corroborada a interpretação errônea que das leis faz o órgão julgador cubano, pois ainda que o artigo 88 do Código Civil expresse que a reparação do dano moral compreende a retratação pública do ofensor, isso não restringe a adopção da compensação pecuniária, a que pode ser aplicada através da interpretação análoga do artigo 38 do próprio corpo legal, o qual dispõe diferentes vias para fazer efetiva a reparação da vítima de um dano, qualquer que seja sua natureza, compreendendo tanto a retratação pública do ofensor quanto a reparação econômica a favor do lesado. Este artigo deve ser interpretado e aplicado de forma conjunta pelos juízes sempre que aconteça um dano extrapatrimonial que infrinja de forma injustificada a dignidade do ser humano.

De igual forma, foi valorado o tratamento concedido ao dano moral no Brasil; o que, embora desfrute de ampla regulação civil e constitucional, vem se 
5.

Conclusão.

reparando in re ipsa evidenciando-se uma indústria do dano extrapatrimonial pela proliferação das demandas que exigem uma tutela econômica ante um suposto prejuízo desse caráter. Em relação à atuação do poder judicial brasileiro corroborou-se que o número de demandas tuteladas é exorbitante, o que ratifica a pouca seriedade e banalidade dos litígios apresentados, concedendo-se na maioria dos assuntos pesquisados uma quantia monetária excessiva.

Verificou-se que quase todas as decisões pesquisadas foram fundamentadas no Código de Defesa do Consumidor, adotando os julgadores brasileiros a Teoria do Risco para conceder a reparação econômica da lide, sustentada no dano in re ipsa e valorando as consequências dos fatos geradores de um sentimento negativo no lesado. Os poucos juízes que não concederam reparação econômica fundamentaram suas decisões nas consequências do dano, rejeitando a indenização quando o prejuízo provocava meros dissabores e aborrecimentos.

Ficou ratificado que o juiz brasileiro resolvia o assunto tendo em consideração a mensuração da dor, do sofrimento, da humilhação, enfim, de estados anímicos negativos provocados à vítima. Sendo a jurisprudência brasileira quase sempre optante pela corrente doutrinária que define o dano moral como abalo e sofrimento psicológico, sendo confundido com as suas possíveis consequências, as que não devem ser consideradas para configurar um dano, senão que se empregariam na adequação do quantum indenizatório.

Comprovou-se que nas decisões judiciais adotadas pelo TJRJ não se ressarce o dano material, embora se encontre configurado, concedendo a reparação por um dano moral ante a situação frustrante e desagradável ocasionada à vítima do detrimento. Nesse tribunal não se realiza uma valoração apropriada dos elementos da responsabilidade civil, existindo equívoco ao definir o que é o dano moral, ficando esquecida a valoração da culpa e concedendo-se uma análise precária do nexo causal, o que influencia negativamente na adequação do quantum indenizatório, que se concede através de uma quantia monetária elevada justificada no dano punitivo como meio de castigo ao ofensor.

Nenhuma das decisões judiciais esteve fundamentada no princípio constitucional da dignidade humana, sempre que foi concedida a reparação se vinculava o dano ao sofrimento psíquico ou à integridade física; argumentando as sentenças através do método bifásico, pelo qual se quantifica o dano moral considerando as condições econômicas da vítima e do lesante, critérios que 
5.

invertem a lógica do Estado Democrático de Direito, violando assim o princípio constitucional da igualdade, pois fornece um pago maior àqueles que ostentam maiores benefícios econômicos em detrimento dos menos favorecidos.

Foram apresentadas propostas sustentadas no princípio da dignidade humana e a adoção do direito civil-constitucional, ratificando a necessidade de aplicar de forma unificada o arcabouço jurídico de cada sistema, a teor dos preceitos constitucionais. O conceito do dano moral ainda é uma questão discutível em ambos os países, deve-se configurar ante a lesão injusta do princípio constitucional da dignidade humana.

Ficou evidenciada a necessidade de que o Estado assuma uma função mais ativa na reparação do dano moral, ao ser o principal encarregado da proteção do indivíduo; através do efetivo funcionamento de suas instituições. Percebendo-se o papel essencial que poderia ter o sistema de Seguros e a instituição da Seguridade Social na reparação dos danos morais que atinjam a toda a coletividade, devendo responder a sociedade de forma geral ante a comissão de um prejuízo derivado de uma atividade arriscada desenvolvida de forma habitual, modo de agir que vem justificado pelo princípio de solidariedade. Mas, quando se comprove a culpa do causador do dano, então ele deve acarrear individualmente os efeitos de seus atos.

Se bem a lei civil cubana não oferece um procedimento normativo em relação à reparação do dano moral, pode ser adotado através da normativa que regula o processo de alimentos a partir dos artigos 121 e seguintes do Código de Família em relação aos artigos 368-371 da Lei Processual.

Igualmente, devem ser aproveitados os preceitos contidos nas normas infraconstitucionais, cuja valoração permite a reparação econômica do dano moral em sede civil. Deve-se aplicar de forma extensiva o articulado do Decreto Lei ${ }^{\circ}$ 209 de 2000, justificado no direito civil-constitucional e na dignidade humana. A aplicação dessa lei possibilita a preservação do direito de igualdade e a reparação justa e proporcional do lesado através da retratação pública do ofensor e o pago pecuniário, com independência de quem seja o ofensor. Igualmente, o mecanismo da Caixa de Ressarcimento deve aplicar-se sempre e quando exista um dano moral derivado do delito, pois, nesses casos, só se ressarcem os danos patrimoniais que decorreram do ato ilícito penal, ficando o dano moral irresarcido.

Os julgadores brasileiros não consideram outras vias efetivas pelas quais se pode ressarcir o lesado, sem necessidade de outorgar uma quantia econômica. 
5.

Existe a possibilidade da adoção não legislativa da retratação pública do ofensor, como solução alternativa que encontra amparo no direito de resposta previsto no artigo 5 V da Carta Magna, em correspondência com sua regulação na Lei 13.188 de 2015. A retratação pública está inserida no conteúdo desse direito fundamental. Sempre que se configura um dano moral pela veiculação ou manifestação de uma informação que lesa injustamente a dignidade do indivíduo pode adotar-se o direito de resposta, em cujo conteúdo insere-se o direito de defesa do ofendido, e o dever de retratação pública do ofensor pela sua atividade imprópria. A retratação pública possibilita que seja rejeitada a reparação pecuniária ou que se adotem quantias econômicas mais proporcionais com o dano suportado pelo lesado.

Resulta iminente a interpretação civil-constitucional justificada no princípio da dignidade humana. Analisar o dano moral a partir dessa perspectiva é de grande transcendência, ao ser pautadora do reconhecimento e definição do prejuízo moral e da concessão de vias efetivas para a reparação da vítima de forma justa e íntegra, por meio da retratação pública do ofensor e a adoção pecuniária, sempre que o assunto assim o exigir. Os princípios constitucionais da dignidade da pessoa humana, solidariedade social e justiça distributiva; justificam o ressarcimento do dano moral em todo sistema democrático de direito.

Precisa-se da valoração adequada dos elementos da responsabilidade civil, o julgador deve verificar que o dano viole o princípio da dignidade humana, transgrida o dever jurídico pré-estabelecido na sociedade e seja o suficientemente injusto e grave como para lhe conceder amparo judicial; posteriormente deve ser avaliado o nexo causal, comprovando se a conduta infratora foi capaz de gerar o dano. Uma vez confirmados esses aspectos, justifica-se a reparação íntegra, justa e proporcional do danificado, adotando-se todas as medidas possíveis que permitam retorná-lo a sua situação prévia, podendo ser adotadas em ambos os sistemas tanto a retratação pública do ofensor como a compensação econômica do lesado.

Tem se demonstrado que tanto a retratação pública como a reparação pecuniária não logram por si só uma íntegra reparação do lesado. Ambas vias podem coexistir num mesmo caso por dano moral ou podem aplicar-se de forma independente, sempre tomando em consideração o assunto em questão. Os dois sistemas têm aspectos inovadores que podem ser aplicados de forma análoga no outro ordenamento, podendo alcançar-se assim, uma adequada interpretação e aplicação do dano moral e a reparação justa da vítima do prejuízo. 


\section{6. Referências bibliográficas}

ALBALADEJO, M. Derecho Civil, Introducción y Parte General. Barcelona: Bosch, v. II, 1996. 440 p.

ALVAREZ VIGARAY, R. La responsabilidad por daño moral. Anuario de Derecho Civil, España, v. 19, n. 1, p. 81-116, 1966.

BARRENECHEA, J. G. 14Ymedio.com. 14Ymedio.com, 2015. Disponivel em: $<$ http://www.14ymedio.com/blogs/el_hidalgo_rural/elige-presidente-RepublicaCuba_7_1738096174.html>. Acesso em: 29 Julho 2017.

BITTAR, C. A. O Direito Civil na Constituição de 1988. Segunda. ed. São Paulo: Revista dos Tribunais, 1991. 22 p.

BITTAR, C. A. Reparação Civil por Danos Morais. São Paulo: Editora dos Tribunais, 1994. 80,122,137,217,218,229 p.

BODIN DE MORAES, M. C. A Caminho de um direito Civil-Constitucional. Direito Civil, Imobiliário, Agrário e Empresarial, Rio de Janeiro, Junho-Setembro 1993.

BODIN DE MORAES, M. C. Danos à Pessoa Humana. Rio de Janeiro.São Paulo: RENOVAR, 2003. 24,28,29,33,34,37,38,43,51,108-112,157,161,162, $179,228-257,261,263,303 \mathrm{p}$.

BODIN DE MORAES, M. C. Punitive damages em sistemas civilistas: problemas e perspectivas. Revista Trimestral de Direito Civil-RTDC, Rio de Janeiro, v. 18, p. 49, abril-junho 2004.

BODIN DE MORAES, M. C. O Princípio da Dignidade Humana. In: BODIN DE MORAES, M. C., et al. Princípio do Direito Civil Contemporâneo. Rio de Janeiro. São Paulo. Recife: Renovar, 2006.

BONISSONI, R. Direito de Resposta: uma análise após a ADPF N. 130. Universidade Federal do Paraná-UNIVEL. Curitiba, p. 85. 2011.

BORDA, G. A. Tratado de Derecho Civil-Obligaciones. Buenos Aires: AbeledoPerrot, 1998. 132,168,169 p. 
BRASIL, Código Brasileiro de Telecomunicações Lei 4.117 de 27 de agosto de 1962, art.84 modificado e revogado pelo Decreto-Lei 236 de 28 de fevereiro de 1967.

BRASIL, Código de Processo Civil, Lei № 13.105, de 16 de março de 2015, art. 139-143.

BRASIL. Constituição da República Federativa do Brasil, de 5 de outubro de 1988, Preâmbulo art. 1 III, 3, 5 V e X, 7 inciso XXVIII 37, \&6 226.7; 227; 230

BRASIL, Lei de Imprensa 5.250 de 9 de fevereiro de1967, arts. 29, 30 e 75

Lei 5.988 Dos Direitos Autorais de 14 de dezembro de 1973, art. 126

BRASIL. Lei № 5.250, Liberdade de manifestação do pensamento e de informação, de 7 de fevereiro de 1967, arts.

BRASIL, Lei 8.078 de 11 de setembro de 1990, Código de Defesa do Consumidor art.6, VI, VII, 44, 78.

BRASIL, Lei 6.194 Seguro Obrigatório dos Danos, de 19 de dezembro de 1974 modificada pela Lei 8.441 de 13 de julho de 1992

BRASIL. Lei № 10.406, Código Civil do Brasil, de 10 de janeiro de 2002, art. 2, 11, 20 parágrafo único, 264, 402, 403, 884 e ss, 927-954.

BRASIL. Lei № 13.188, Sobre o direito de resposta ou retificação do ofendido em matéria divulgada, publicada ou transmitida por veículo de comunicação social, de 11 de novembro de 2015

CARVALHO LEITE, Fábio. Liberdade de Expressão versus Direito à Honra: 0 Direito de Resposta como sanção preferencial. Pág. 16, MIMEO

CAVALIERI FILHO, S. Programa de Responsabilidade Civil. Quinta. ed. Brasi: MALHEIROS EDITORES, 2004.

CÓDIGO CIVIL PORTUGUÊS artigo 496, Atualizado até Dec.-Lei n.․ 38/2003, de 08.03.(Decreto-Lei № 47344, de 25 de Novembro de 1966).

COMPENSAR, D.-S. [S.I.]: [s.n.], 2017.

CONSTITUCIONAL, E. S. D. P. Delgado Triana, Yanelys; Rodríguez Corría, Reinerio. La Habana: UniJuris, 2012.

COUTO DE CASTRO, G. A Responsabilidade Objetiva No Direito Brasileiro. Terceira. ed. Rio de Janeiro: Forense, 2005.

CUBA, Constitución de la República de Cuba, de 24 de febrero de 1976. Preámbulo, art. 1, 5, 9 a), 16, 26, 42, 43, 53, 61 e 120. Disponível em: 
$<$ http://legislacion.sld.cu/index.php?P=FullRecord\&ID=247>. Acesso em: 05 may. 2017.

CUBA, Decreto-Lei No. 175 de 17 de junho de 1997, Modificativo del Código Penal, artigo 15, G.O. Ext. No. 6 de 26 de junio de 1997, pág. 40.

CUBA, Decreto-Ley 209, de 20 de marzo de 2000, art. 1, 4. Disponível em: <http:/juriscuba.com/legislacion-2/decretos-leyes>. Acesso em: 05 may. 2017.

CUBA, Dictamen № 212, de 8 de enero de 1985. Disponível em: < http://juriscuba.com/legislacion-2/acuerdos-tribunal-supremo/dictamenes-del-200299/>. Acesso em: 05 may. 2017.

CUBA, Instrucción № 104, de 16 de febrero de 1982. Disponível em: < http://juriscuba.com/legislacion-2/instrucciones-tribunal-supremo/> Acesso em: 05 may. 2017.

CUBA, Instrucción № 117, de 11 de octubre de 1984 del Consejo Govierno del Tribunal Supremo Popular. Disponível em: http://juriscuba.com/wpcontent/uploads/2015/10/Inst.-No.-117.pdf. > Acesso em: 20. set. 2017.

CUBA, Ley № 5, Ley de Procedimiento Penal de 13 de agosto de 1977, arts. 275, 463. Disponível em: < http://juriscuba.com/legislacion-2/leyes/>. Acesso em: 05 may 2017.

CUBA, Ley № 7, Ley de Procedimiento Civil, Administrativo, Laboral y Económico de 19 de agosto de 1977, art. 115, 157-158, 244. Disponível em: <http://juriscuba.com/legislacion-2/leyes/>. Acesso em: 05 de may. 2017.

CUBA, Ley № 59, de 16 de Julio de 1987. Código Civil, arts. 4, 6, 8, 38, 45.1, 46.3, 83, 86, 88, 89.1, 91, 138.1, 144.1, 149.1, 155 e Disposición Final Primera . Disponível em:

https://www.gacetaoficial.gob.cu/html/codigo\%20civil\%20lib1.html >. Acesso em: 05 may. 2017.

CUBA, Ley № 62, Código Penal de 29 de diciembre de 1987, arts. 318-321, Título VIII, Capítulos II ao VIII. Disponível em: <http://juriscuba.com/wpcontent/uploads/2015/10/Ley-No.-062-Codigo-Penal1.pdf>. Acesso em: 05 may. 2017.

CUBA, Ley № 83, Ley de la Fiscalía General de la República de 11 de julio de 1997, arts. 75 r),s); 90 ñ), o); 98 i), m); 105 j); 106 d) e Capítulo III. Disponível em: <http://juriscuba.com/legislacion-2/leyes/>. Acesso em: 05 may. 2017. 
CUBA, Ley de la Seguridad Social no. 105, 27 de diciembre del 2008, art. 1, 6, 39, 41. Disponível em: < http://juriscuba.com/wp-content/uploads/2015/10/LeyNo.-105-De-Seguridad-Social-.pdf>. Acesso em 20 set. 2017.

CUBA, Ley no. 113 del Sistema Tributário, 23 de junio del 2012. Disponível em: < http://juriscuba.com/legislacion-2/leyes/>. Acesso em: 20 set. 2017.

CUBA, Ley № 1289, Código de Familia, 14 de febrero de 1975, arts. 2, 85, 121 137, 147, 151 e 155.5. Disponível em: < http://juriscuba.com/wpcontent/uploads/2015/10/Ley-No.1289-Codigo-de-Familia.pdf>. Acesso em: 10 junh. 2017.

CUBA, Reglamento de la Ley 82, Ley de los Tribunales Populares de 11 de julio de 1997, arts. 3, 4, 82-87, 90-92. Disponível em:< http://juriscuba.com/legislacion2/leyes/>. Acesso em: 05 may 2017

DA SILVA PEREIRA, C. M. Responsabilidade Civil. Quinta. ed. Rio de Janeiro: Forense, 1994.

DA SILVA PEREIRA, C. M. Instituições de Direito Civil. Rio de Janeiro-Brasil: Forense, v. I, 2016.

DE AGUIAR DIAS, J. Da Responsabilidade Civil. Décimo primeira. ed. Rio de Janeiro-São Paulo-Recife: [s.n.], 2006.

DE ANDRADE LEVY, D. Responsabilidade Civil. De um Direito dos Danos a um Direito de Condutas Lesivas. São Paulo: Atlas S.A, 2012.

DÍAZ PAIRÓ, A. Teoría General de las Obligaciones. México: [s.n.], v. II, 1997.

DÍEZ PICAZO, L. La responsabilidad civil hoy. Anuario de Derecho Civil, España, n. Fascículo 4, 1979.

DÍEZ PICAZO, L. La responsabilidad civil hoy. Anuario de Derecho Civil, España, 1979.

DÍEZ PICAZO, L. Codificación, descodificación y recodificación. Anuario de Derecho Civil, España, n. 2, 1992.

DíEZ PICAZO, L. Derecho de Daños. Madrid: Civitas, 1999. 28,46,85,224, 239, 240, 291, 292, 306-309, 328, 329 p.

DIEZ PICAZO, L. Culpa y Riesgo en la responsabilidad Civil Extracontractual. La Justicia Uruguaya, Revista Jurídica, Uruguay, v. 153, n. 153, p. 153, 2016.

ECURED. EcuRed. Disponivel em: <https://www.ecured.cu/Constituci\%C3\%B3n_de_la_Rep\%C3\%BAblica_de_Cub 
a\#Constituci.C3.B3n_de_la_Rep.C3.BAblica_de_Cuba_.281976.29>. Acesso em: 31 Junho 2017.

ECURED.

EcuRed.

Disponivel

em:

<https://www.ecured.cu/Sistema_electoral_cubano>. Acesso em: 29 Julho 2017.

ESPAÑA. Real Decreto de 24 de julio de 1889, Código Civil Español, art.1101. Disponível $\quad$ em:< $\quad$ http://www.boe.es/buscar/pdf/1889/BOE-A-1889-4763consolidado.pdf>. Acesso em: 09 set. 2017.

FEDERICO DE LORENZO, M. EI Daño Injusto en la Responsabilidad Civil. Buenos Aires: Abeledo-Perrot.

FERNÁNDEZ BULTÉ, J. Filosofía del Derecho. La Habana: Félix Varela, 1997. $58 \mathrm{p}$.

GARGARELLA, R. La sala de máquinas de la Constitución dos siglos de constitucionalismo en América Latina (1810-2010). Buenos Aires: Kats Editores, 2014. $363 \mathrm{p}$.

HOBBES, T. Leviatã ou Matéria, Forma e Poder de uma República Eclesiástica e Civil. São Paulo: Martins Fontes, 2003. 71 p.

ISABEL, G. F.; RIVERA RIQUENES, J. Informatización de la impartición de justicia, Tribunales Populares Cubanos. 8va Conferencia Científica Internacional da la Universidad de Holguín. Holguín: [s.n.]. 2017.

JURIS Cuba. Juris Cuba, 2017. Disponivel em: <http:/juriscuba.com/wpcontent/uploads/2015/10/Inst.-No.-109.pdf>. Acesso em: 10 julho 2017.

KANT, I. A Metafísica dos Costumes. Primera. ed. São Paulo: EDIPRO, 2003. $232 \mathrm{p}$.

LARENZ, K. Derecho Civil, Parte General. Madrid: [s.n.], 1978. 45-46 p.

LEÓN IGLESIAS, J. M. Evolución de las ideas filosófico penales en Cuba. El Código de Defensa Social y otras normativas penales (1938-1958). Revista de historia del derecho, Buenos Aires, n. 45, Junio 2013.

LEWICKI, B. O direito civil-constitucional e as convergências no estudo do direito privado brasileiro. Instituto Avançado de Direito, 2003.

LIMA, A. Culpa e Risco. Segunda. ed. São Paulo: Revista dos Tribunais, 1999.

LLAMBIAS, J. J.; BENEGAS RAFFO, P.; SASSOT, R. A. Manual de Derecho Civil-Obligaciones. undécima. ed. Buenos Aires: Perrot, 1997. 102,112 p.

LOUZADA BERNARDO, W. D. O. Dano Moral: Critérios de Fixação de Valor. Rio de Janeiro: Renovar, 2005. 74 e 78 p. 
MARTÍNEZ HEREDIA, F. Desafíos del socialismo cubano. La Habana: Centro de Estudios sobre América, 1988. 10-20 p.

MEDINA CUENCA, A. Leyes Penales cubanas comentadas. [S.I.]: UNIJURIS, 2013.

MELO DA SILVA, W. O Dano Moral e sua Reparação. Terceira. ed. Rio de Janeiro: Forense, 1999.

MONTEIRO FILHO, C. E. D. R. Elementos de Responsabilidade Civil por Dano Moral. Rio de Janeiro.São Paulo: RENOVAR, 2000. 39-40,152,155,156 p. MULHOLLAND, C. S. A Responsabilidade Civil por Presunção de Causalidade. Rio de Janeiro: GZ Editora, 2010. 21,22,25,27,35,40,41,54-57,81 p.

OJEDA RODRíGUEZ, N. D. L. C.; TERESA, V. D. Teoria General de las Obligaciones. Comentarios al Código Civil Cubano. La Habana: [s.n.], 2000. PÉREZ GALLARDO, L. Tras las huellas del legislador del Código civil de los cubanos. Revista de derecho Privado, España, n. 84, noviembre 2000.

PÉREZ GALLARDO, L. Breves notas sobre el Código Civil cubano a propósito de los veinte de su promulgación. Revista Cubana de Derecho, La Habana, n. 30, p. 115-129, diciembre 2007.

PÉREZ GALLARDO, L. et al. Lectura de Derecho de Obligaciones y Contratos. La Habana: [s.n.], 1999. 25,58,60,303 p.

PÉREZ VÉLIZ, A. EL Derecho al Honor en Cuba. Fundamentos para su reforma. Revista Mexicana de Derecho Constitucional, México, n. 35, p. 151-197, juliodiciembre 2016.

PERLINGIERI, P. Perfis de Direito Civil: uma introdução ao direito civil constitucional. Terceira. ed. Rio de Janeiro: Renovar, 1997. 5 e 6, 44 e 45 p.

PIETRO, P. O Direito Civil na Legalidade Constitucional. Rio de Janeiro: Renovar, 2008.

RÉGIMEN Político. Régimen Político. Disponivel em: <http://www.regimenpolitico.com/paises/regimen-politico-cuba.php>. Acesso em: 31 Julho 2017.

RODRÍGUEZ CORRÍA, R. El daño moral. Concepto y resarcimiento. Universidad de la Habana. La Habana. 2003.

SÁNCHEZ, Y. Generación Y. Generación Y. Disponivel em: <http://www.14ymedio.com/blogs/generacion_y/>. Acesso em: 31 Julho 2017. 
SANSEVERINO, P. D. T. A Liberdade de Expressão e o Dano Moral no Direito Brasileiro. Seminario Libertad de Expresión, Santiago de Chile, 2011.

SCHREIBER, A. Novas Tendências da Responsabilidade Civil brasileira. Revista Trimestral de Direito Civil-RTDC, Rio de Janeiro, v. 22, p. 46, abril-junho 2005. SCHREIBER, A. Novos Paradigmas da Responsabilidade Civil. Da Erosão dos Filtros da Reparação à Diluição dos Danos. São Paulo: Atlas, 2007. 6,7,16-20, 23, 35, 48,52-61,79, 87-89, 123, 124,131 p.

SCHREIBER, A. Direitos da Personalidade. São Paulo: Atlas. S.A, 2011. 16 p.

SILVA GUERRA, S. A Liberdade de Imprensa e o Direito à Imagem. Segunda. ed. [S.I.]: Renovar, 2004.

SILVA LEÓN, A. Breve Historia de la Revolución Cubana. La Habana: Ciencias Sociales, 2003. 10 p.

SMITH RAMOS, G. Derecho Penal, Parte General II. La Habana: ENSPES, 1983.

TEPEDINO, G. Temas de Direito Civi. Terceira. ed. Rio de Janeiro. São Paulo. Recife: Renovar, 2004.

VALDÉS DÍAZ, C. D. C. et al. Derecho Civil Parte General. La Habana: [s.n.], 2000. 111,117,175,309,318,320,324,325 p.

VEGA CARDONA, R. J.; ORDELÍN FONT, J. L. Presupuestos para la Determinación del Quantum Indemnizatorio del Daño Moral en Cuba. Perspectivas para una reforma. Revista de la Facultad de Ciencias Sociales y Jurídicas de Elche, España, v. I, n. 8, p. 284-301, Febrero 2012. 